Historic, Archive Document

Do not assume content reflects current scientific knowledge, policies, or practices. 



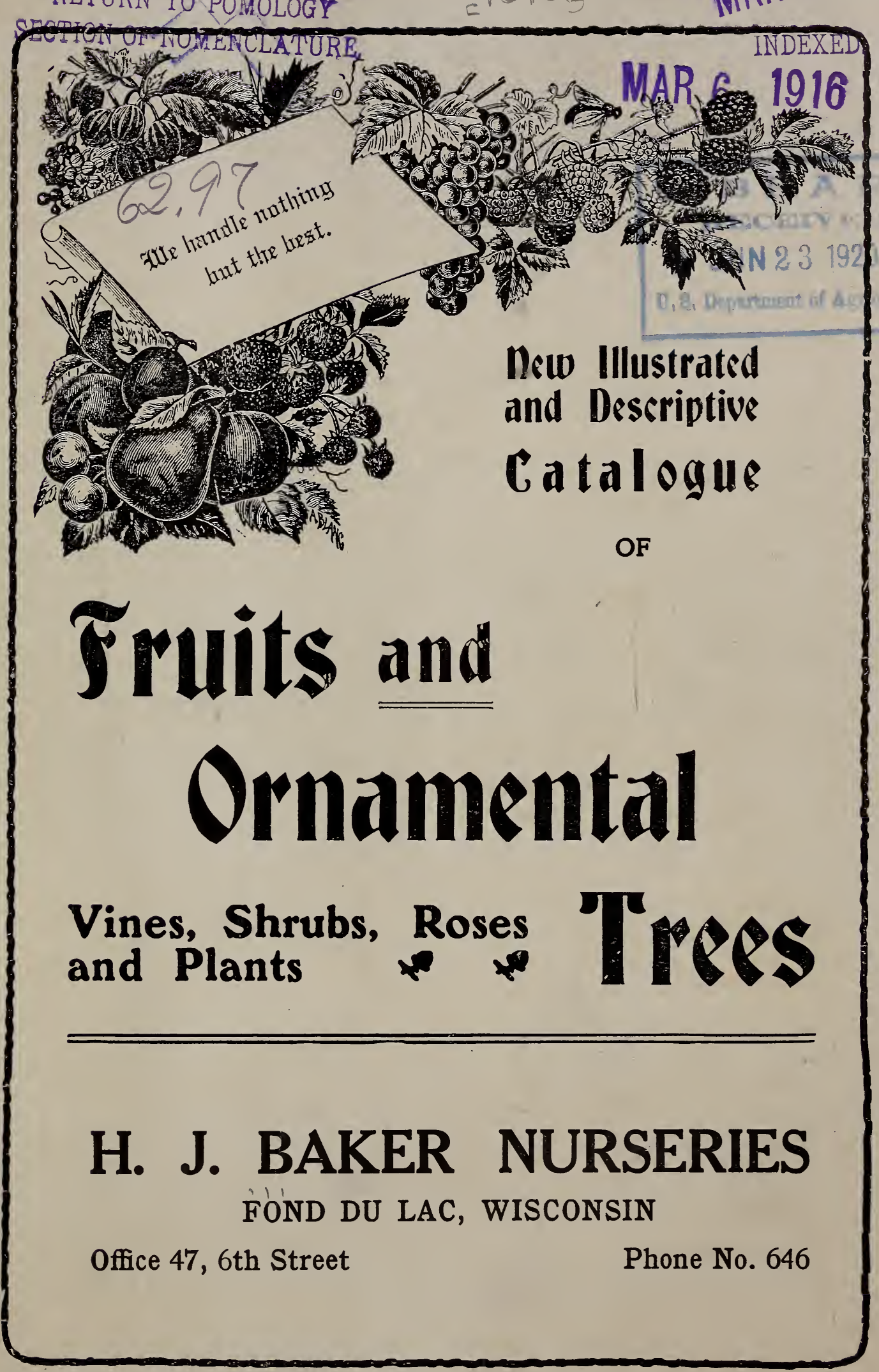




\section{SPRAYING CALENDAR}

EXPLANATION-While the number of applications recommended will be found desirable in seasons when the fungi are particularly troublesome, a smaller number may often suffice. An asterisk (*) cautions against spraying with poisons while the plants are in blossom; $t$ wo asterisks (**) indicate that there is danger in making an application within 3 weeks of the time the fruit is to be used as food.

\begin{tabular}{|c|c|c|c|c|}
\hline PLANTS & 1st Application & 2d Application & 3d Application & 4th Application \\
\hline $\begin{array}{l}\text { APPLE, } \\
\text { Scab, codling moth } \\
\text { bud moth, caterpillar, } \\
\text { canker worm. }\end{array}$ & $\begin{array}{l}\text { After the blossoms } \\
\text { h have formed, but be- } \\
\text { fore they open, Bor- } \\
\text { deaux. }\end{array}$ & $\begin{array}{l}\text { Within a week after } \\
\text { blossoms fall, Bord- } \\
\text { eaux and Paris Green. }\end{array}$ & $\begin{array}{l}\text { 10 to } 14 \text { days later, } \\
\text { - Bordeaux and Paris } \\
\text { Green. }\end{array}$ & $\begin{array}{l}10 \text { to } 14 \text { days later } \\
\text { Bordeaux. }\end{array}$ \\
\hline $\begin{array}{l}\text { CHERRY, } \\
\text { Rot, a phis, curculio } \\
\text { slug, knot. }\end{array}$ & $\begin{array}{l}\text { As flower buds ap- } \\
\text { pear, but before they } \\
\text { open, Bordeaux; for } \\
\text { aphis use Kerosen } \\
\text { Emulsion. }\end{array}$ & $\begin{array}{l}\text { When fruit has set, } \\
\text { Bordeaux and Paris } \\
\text { Green.* }\end{array}$ & $\begin{array}{l}10 \text { to } 14 \text { days later, } \\
\text { sif signs of rot appear, } \\
\text { repeat. }\end{array}$ & $\begin{array}{l}10 \text { to } 14 \text { days later, } \\
\text { Ammoniacal Carbo- } \\
\text { nate of Copper. }\end{array}$ \\
\hline $\begin{array}{l}\text { CURRANT, } \\
\text { Mildew, worms. }\end{array}$ & $\begin{array}{l}\text { As soon as worms } \\
\text { dre found on lower } \\
\text { and inner leaves } \\
\text { Paris Green. }\end{array}$ & $\begin{array}{l}\text { If they reappear, re- } \\
\text { peat, adding Bor- } \\
\text { deaux for mildew.** }\end{array}$ & $\begin{array}{l}\text { If worms still trouble } \\
\text { Pyrethrum or Helle- } \\
\text { bore.* }\end{array}$ & $\begin{array}{l}\text { After fruit is picked } \\
\text { Bordea ux. }\end{array}$ \\
\hline $\begin{array}{l}\text { GUOSEBERRY, } \\
\text { Mildew, worms. }\end{array}$ & $\begin{array}{l}\text { As leaves open, Bor- } \\
\text { deaux and Paris } \\
\text { Green. }\end{array}$ & $\begin{array}{l}\text { In } 10 \text { to } 14 \text { days re- } \\
\text { peat with both. }\end{array}$ & $\begin{array}{l}10 \text { to } 14 \text { days later, } \\
\text { Sulphide Potash, on } \\
\text { English varieties. }\end{array}$ & $\begin{array}{l}10 \text { to } 14 \text { days later, } \\
\text { repeat. }\end{array}$ \\
\hline $\begin{array}{l}\text { GRAPE, } \\
\text { Fungous diseases, } \\
\text { flea beetle }\end{array}$ & $\begin{array}{l}\text { When first leaves are } \\
\text { half grown, Bordeaux } \\
\text { and Paris Green. }\end{array}$ & $\begin{array}{l}\text { As soon as the fruit } \\
\text { has set, repeat.* }\end{array}$ & $\begin{array}{l}10 \text { to } 14 \text { days later, } \\
\text { repeat. }\end{array}$ & $\begin{array}{l}10 \text { to } 14 \text { days later, } \\
\text { if disease is present, } \\
\text { apply Bordeaux. }\end{array}$ \\
\hline $\begin{array}{l}\text { PEACH, } \\
\text { APRICOT, } \\
\text { Rot, curculio, leaf } \\
\text { curl, mildew. }\end{array}$ & $\begin{array}{l}\text { B e for e blossoms } \\
\text { open, Bordeaux. }\end{array}$ & $\begin{array}{l}\text { Within a week after } \\
\text { fruit has set, Bor- } \\
\text { deaux and Paris Green }\end{array}$ & $\begin{array}{l}7 \text { to } 12 \text { days later, } \\
\text {-repeat. }\end{array}$ & $\begin{array}{l}7 \text { to } 12 \text { days later, } \\
\text { repeat. }\end{array}$ \\
\hline $\begin{array}{l}\text { PEAR, } \\
\text { Leaf blight, scab, } \\
\text { psylla, codling moth. }\end{array}$ & $\begin{array}{l}\text { Just before blossoms } \\
\text { open, Bordeaux.* }\end{array}$ & $\begin{array}{l}\text { Within a week after } \\
\text { blossoms fall, Bor- } \\
\text { deaux and Paris } \\
\text { Green. }\end{array}$ & $\begin{array}{l}8 \text { to } 12 \text { days later, } \\
\text { repeat. }\end{array}$ & $\begin{array}{l}10 \text { to } 16 \text { days later, } \\
\text { Bordeaux. }\end{array}$ \\
\hline $\begin{array}{l}\text { PLUM, } \\
\text { Fungous diseases, } \\
\text { rot, curculio, knot. }\end{array}$ & $\begin{array}{l}\text { When blossom buds } \\
\text { appear, but before } \\
\text { they open, Bordeaux. }\end{array}$ & $\begin{array}{l}\text { When fruit has set, } \\
\text { Bordeaux and Paris } \\
\text { Green.* }\end{array}$ & $\begin{array}{l}10 \text { to } 20 \text { days later, } \\
\text { Bordeaux. } \\
10 \text { to } 12 \text { days later, } \\
\text { repeat. }\end{array}$ & $\begin{array}{l}\text { Note-If black } \\
\text { knots are found on } \\
\text { plums or cherry trees } \\
\text { they should at once } \\
\text { be cut out and } \\
\text { burned. } \\
10 \text { to } 20 \text { days later, } \\
\text { Bordeaux. }\end{array}$ \\
\hline $\begin{array}{l}\text { BLACKBERRY, } \\
\text { RASPBERRY, } \\
\text { Anthracnose, rust. }\end{array}$ & $\begin{array}{l}\text { Cut out canes badly } \\
\text { diseased with anthra- } \\
\text { cnose and burn. Be- } \\
\text { fore buds open, spray } \\
\text { with Copper Sulphate }\end{array}$ & $\begin{array}{l}\text { When new canes ap- } \\
\text { pear. Bordeaux and } \\
\text { Paris Green.** 10 } \\
\text { days later, Bordeaux } \\
\text { and Paris Green. }\end{array}$ & $\begin{array}{l}10 \text { to } 14 \text { days later, } \\
\text { repeat.** }\end{array}$ & $\begin{array}{l}\text { Note-If red rust } \\
\text { appears, the entire } \\
\text { stool affected should } \\
\text { be grubbed out and } \\
\text { burned. }\end{array}$ \\
\hline $\begin{array}{l}\text { ROSE, } \\
\text { Aphis, worms. }\end{array}$ & $\begin{array}{l}\text { Kerosine Emuslion } \\
\text { for aphis. }\end{array}$ & & $\begin{array}{l}\text { Afterwards keep lice } \\
\text { and caterpillars off by } \\
\text { turning a fine stream } \\
\text { from hose on under } \\
\text { side of leaves. }\end{array}$ & \\
\hline
\end{tabular}

Do not spray with arsenites or copper compounds within three weeks of the time the sprayed portions are to be eaten. While there would be no danger of fatal effects resulting, it is best not to run any risk. Bordeaux mixture and other lime compounds should not be used upon rough or full-grown vines even as late as that time. Not only does the lime disfigure the fruit, but the amount of copper is large. 


\section{RETERN TO POHOLOGY}

SECTION OF NOMENCLETURE.

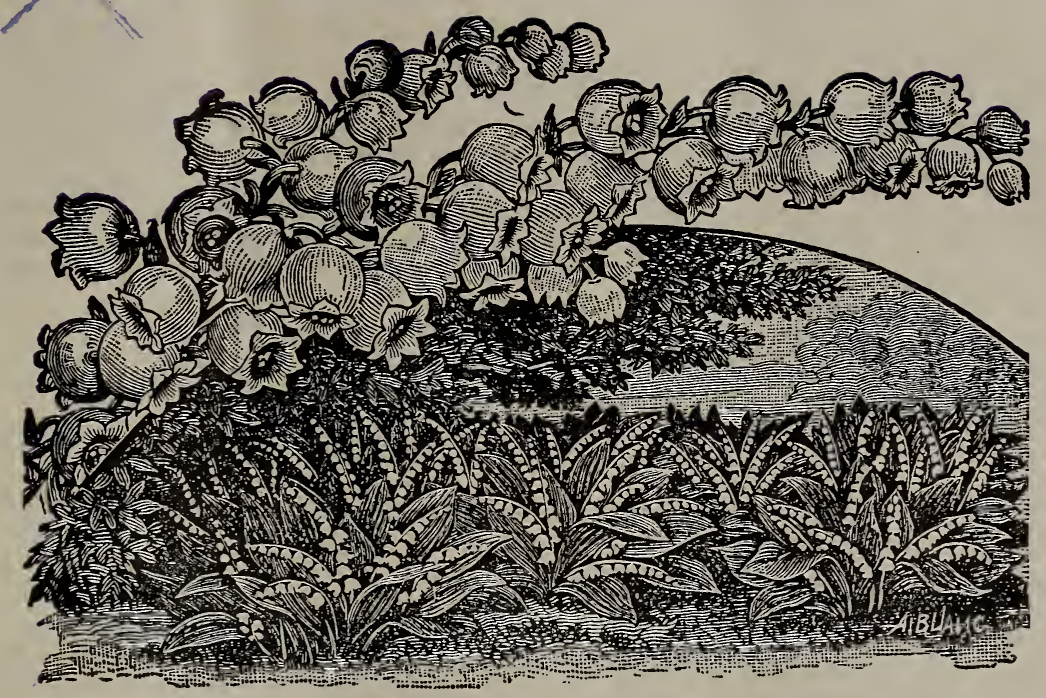

INTRODUCTORY

\section{To Our Numerous Friends and Customers:}

The following careful descriptions are of far more value in making successful selections than the grandest set of pictures would be. Therefore, study the descriptions and preserve this catalogue, for it will be found a most valuable horticultural work of reference.

Purchasers are requested to name the mode of conveyance by which they desire shipments; otherwise we will dispatch to the best of our judgment.

Parties desiring stock shipped per express C. O. D. must accompany their orders with cash to one-half the amount, or make satisfactory arrangements for payment of their bill.

Orders should always be placed early before assortments are broken. It is often impossible to procure varieties wanted if orders are delayed until time for planting. When spring planting is preferred, we will book orders in fall and set stock aside in cellar ready for shipment at any desired date.

WARRANTY-While we exercise the greatest care to have all our trees and plants genuine and reliable, and hold ourselves prepared to replace, on proper proof, all that may prove untrue to name, we do not give any warranty, expressed or implied, and in case of error on our part, it is mutually agreed between the purchaser and ourselves that we shall not, at any time, be held responsible for a greater amount than the original price of the trees.

CLAIMS-All claims for errors and deficiencies must be made within ten days after the receipt of the stock. We desire to be notified of mistakes as early as possible, so we may rectify the same without delay.

We aim to have every deal a satisfactory one.

Our Stock is first class and will be packed in the best manner.

Our Prices are as low as we can afford for first class stock.

We are now in position to promptly execute orders for goods mentioned in this catalogue, and hope to have the pleasure of supplying your wants.

\section{SUGGESTIONS TO PLANTERS}

Success depends in a large measure on the treatment given stock after it is received by planters. Avoid all unnecessary exposure to the air. As soon as received it should be heeled in, so that mellow earth will come in contact with the roots. When planting take out but few at a time. One hour of exposure to hot sun or drying wind is sure death to many trees. 
Cut off the ends of all bruised or broken roots with a sharp knife, making a clean cut. If it be a standard tree for the orchard, trim it up to four or five limbs, suitable to form the top, and cut each of the side limbs back to a bud four or five inches from the body of the tree, leaving the leader or central limb from eight to twelve inches long. When there are no side limbs suitable for this purpose, the tree should be divested of all its branches and headed back to a proper height to form the top.

In properly prepared ground the holes need not be dug much larger than necessary to receive the roots in their original position, but it is always best to dig some distance below the roots and refill with surface soil. In planting in sod the holes should be dug three times the size necessary in well plowed land.

Remove all label wire from trees that it may not cut the branches.

As soon as planted, five or six inches of coarse manure or other litter should be spread over the ground about the tree, four or five feet in diameter; this will keep the surface moist, and aid the tree during dry weather.

No grass or grain crops should be raised among fruit trees until they have attained bearing size.

If the trees are received in a frozen state, place the package unopened in the cellar, away from the frost and heat, until thawed out, and then unpack.

"Heeling in" Stock Received in the Fall-To insure success you have only to get the trees before freezing weather and bury them in the following manner:

Choose a dry spot where no water will stand during the winter, with no grass near to invite mice. Dig a trench, throwing out enough dirt to admit one layer of roots below the surface, and place the trees in it inclined at an angle of 45 degrees or more. Widen the trench, throwing the soil among the roots in position, place another layer in the trench, reclining the tops on the others and so on until all are in the trench; then water thoroughly. Finish by throwing up more soil until the tips of the trees are fully covered. It is also well to bank up the earth around the sides to insure more thorough protection. Care should be taken to fill solid all the interstices among the roots. Too much care in doing this cannot be insisted upon, as every root which is not in close contact with the soil is sure to be killed. In the spring the trees will be on hand for transplanting at the earliest moment possible to do the work.

\section{Number of Trees Sufficient to Plant an Acre.}

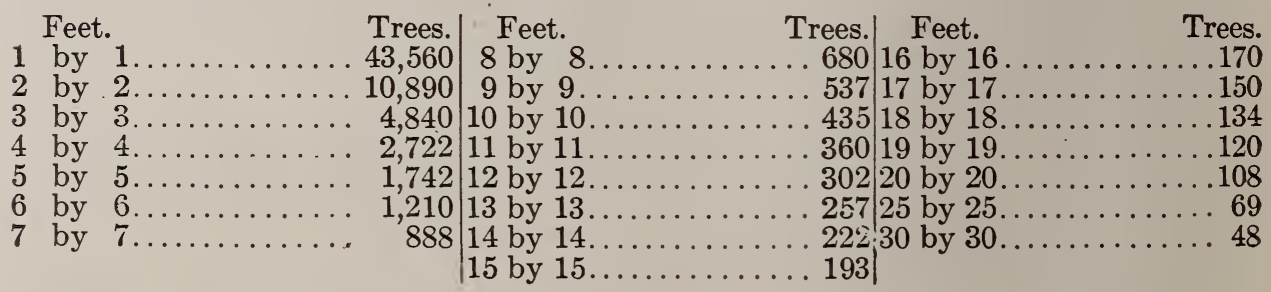

Distances for Planting.

Feet Apart.

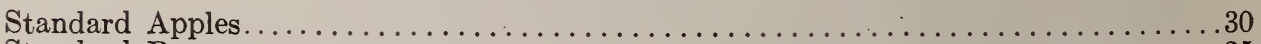

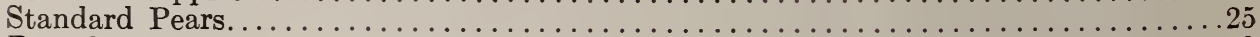

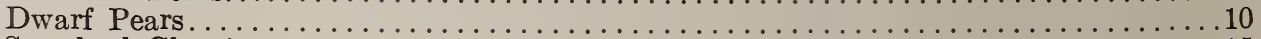

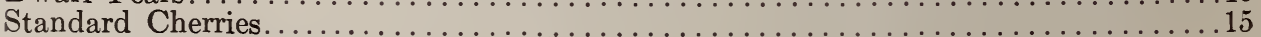

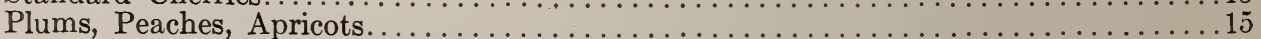

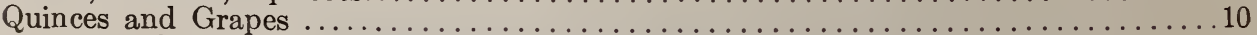

Currants, Gooseberries, Raspberries and Rhubarb........................

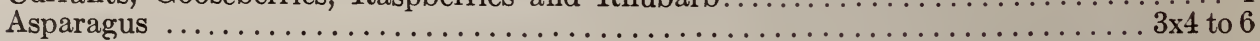

- The number of plants required for an acre, at any given distance apart, may be ascertained by dividing the number of square feet in an acre $(43,560)$ by the number of square feet given to each plant, which is obtained by multiplying the distance between rows by the distance between plants. 


\section{Apples}

Taking into consideration its hardiness, productiveness and general commercial value, the apple stands at the head of our list of fruits. In selecting the most important varieties for cultivation, it has been our constant aim to secure only those of standard excellence, and in no instance to recommend a novelty without ascertaining its history from a reliable source. Our main crop of trees consists principally of the following varieties, yet we can also supply several other sorts of local reputation.

\section{SUMMER APPLES}

BENONI-Medium; roundish; pale yellow, shaded with crimson, juicy, tender subacid.- August.

CAROLINA RED JUNE-Tree a moderate, upright grower; an early and abundant bearer. Fruit small to medium, oblong, surface smooth, color dark red, with white ground; flesh white, very tender, fine grained, juicy, acid. June and July.

DUCHESS OF OLDENBURG-A large, beautiful apple, roundish. Streaked red and yellow. Tender, juicy and pleasant. Tree a vigorous, fine grower and abundant bearer. Very hardy. September.

\section{EARLY HARVEST.-}

Tree healthy, vigorous and a good bearer. Fruit medium size, nearly round somewhat flattened; surface smooth, clear, waxy yellow, rarely blushed; flesh tender, juicy, acid to sub-acid, flavor good. July.

GOLDEN SWEET.Large, pale yellow, very sweet and good; good bearer; free. August.

EAR L Y S T R A BERRY.-Medium, roundish; handsomely striped with red; excellent; productive. July and August.

RED ASTRACHAN.Tree vigorous, upright, hardy and productive. Fruit medium to large; surface smooth, marbled and striped on greenish yellow; flavor acid.

RED JUNE.-Medium, red; flesh white, tender; juicy, good flavor. Abundant bearer. Last of June.

\section{SOPES OF WINE.-} Medium size; red; flesh white, often stained; mild and pleasant; productive; free. July and August.

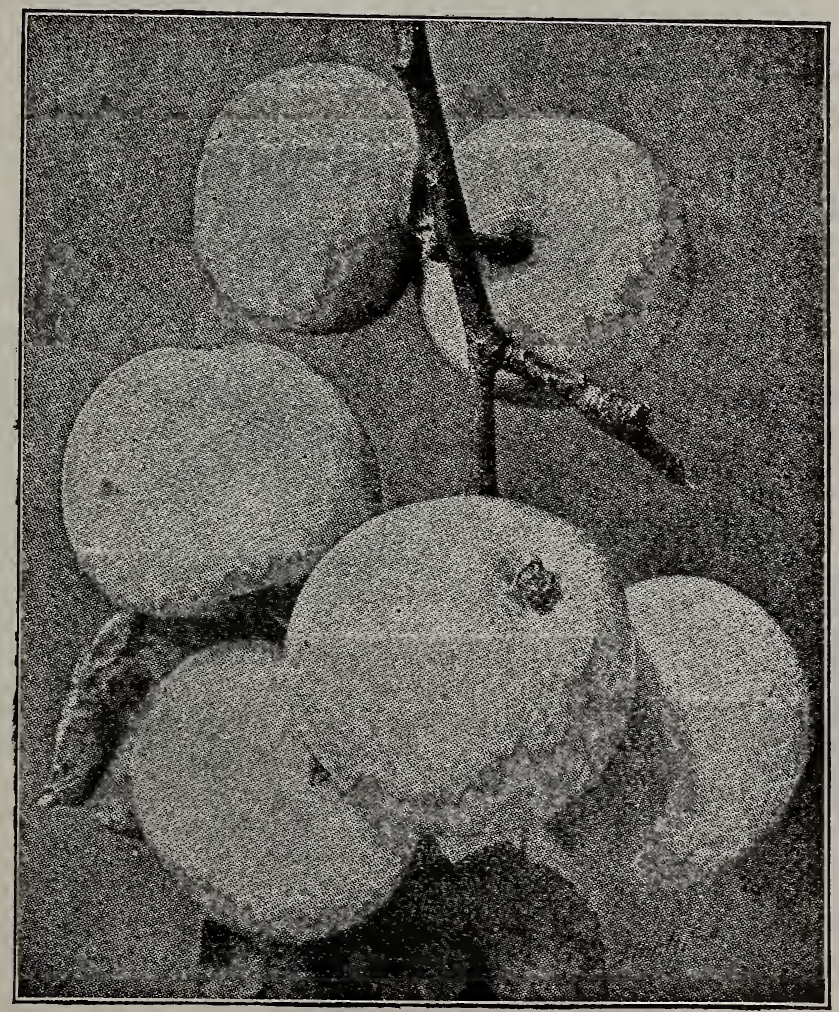


SWEET BOUGH.-Large, pale greenish yellow, tender and sweet; good bearer; moderate. July and August.

SWEET JUNE.-Tree is strong, upright, very productive. Fruit small to medium, round; greenish yellow; flesh white, fine grained, tender. June and July.

TETOFSKY.- Tree upright, dwarfish grower; bears annually and extremely early. Very backward, and hard to grow in nursery. July and August.

YELLOW TRANSPARENT.-A Russian apple. The tree is a hardy, upright grower; regular and early bearer, medium size. Color a rich, transparent yellow with a faint flush on sunny side; flesh melting, juicy, sub-acid.

\section{AUTUMN APPLES}

ALEXANDER.-(Emperor Russia.)-Large, deep red or crimson; flesh yellowish white, crisp, tender, with pleasant flavor; very hardy; mod. October.

AUTUMN STRAWBERRY-Medium, roundish, inclined to oval; streaked with red. Productive and desirable. Not hardy north. September.

CHENANGO-Medium, oblong; skin whitish, splashed and mottled with red. Fruit handsome, esteemed for table and especially prized for market. Tree vigorous. Not hardy north. August and September.

DOMINL. (Well's English Red Streak.)-Medium, skin greenish yellow; flesh very tender and pleasant; tree vigorous and prolific. October to December.

FAMEUSE. (Snow Apple.)-Medium size, roundish; crimson, sometimes striped in northern localities. Flesh snowy white; very tender, fine, juicy, mild, sub-acid; one of the finest dessert fruits. Hardy and prolific. Very popular. October and December.

HAAS -Large, flat, ribbed or quartered; yellowish green, streaked and nearly covered with dull, brownich red; flesh white, tender, juicy, sub-acid. Quality fair. Tree an extremely vigorous grower, hardy. October and November.

LOWELL OR ORANGE-Large, roundish, slightly conical; green, becoming rich yellow; surface oily; flesh yellowish white, sub-acid, excellent; good bearer; free. September.

MAIDEN BLUSH - Large, smooth, regular, evenly shaded red cheek or blush on a pale yellow ground; flesh white, tender, sprightly, with a pleasant sub-acid flavor; bears large crops; free. August to October.

MASON'S SWEET-Large, pale yellow with red cheek; tender, rich and good; fine bearer; vigorous. September.

RAMBO-Medium; yellow, striped with red. Fruit mild, tender, good. September to November.

R A M S D E L L SWEET-

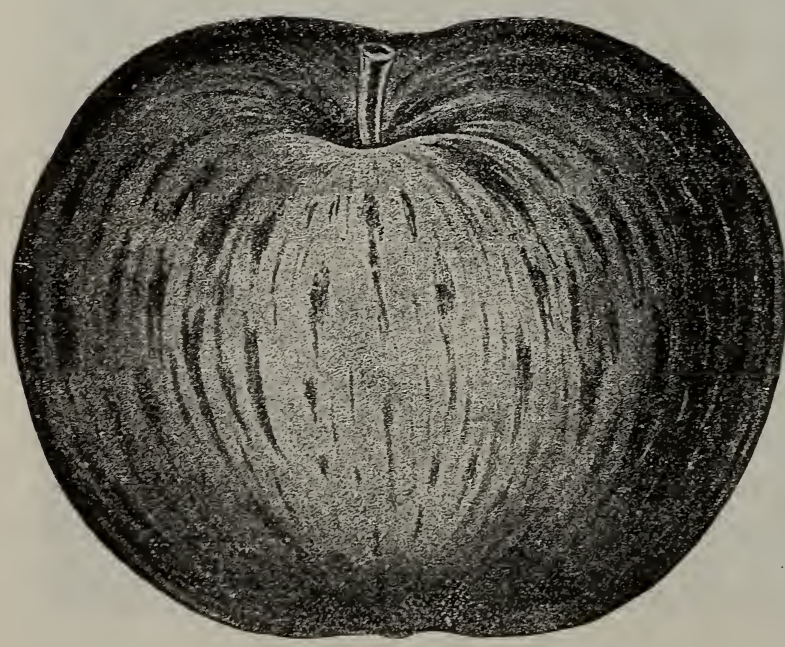

Rather large, oblong; dark red; best fall sweet. Tree vigorous, upright, productive, hardy. October to December.

UTTER. (Red) - Rather large; red-striped. Very hardy on prairie; productive and of excellent quality. Immensely popular where known. September to December.

WOLF RIVER - Extra large and handsome; deep red; excellent for cooking. Extremely hardy in the north. Probably the largest red apple adapted to this region. September to November.

WEALTHY-Origin, Minnesota. Large, round; red; very handsome; fine quality; good grower. Perfectly hardy and most reliable. Very popular throughout the north. Long WEALTHY keeper in cold storage. October to January. 


\section{WINTER APPLES}

AKIN RED-This apple is rapidly coming to the front. The original tree, over sixty years old, is still living and bears large crcps annually. It is a deep, red apple of medium size and most excellent quality. Very productive and a late keeper.

ARKANSAS BLACK-Vigorous, upright grower. Fruit medium to large; fine flavor, beautiful dark color, almost black; flesh yellowish; slightly sub-acid, crisp. One of the best for cooking. January to March.

BALDWIN-Large; deep, bright red. Flesh juicy, crisp and of good flavor. Tree vigorous in the East and South, though not sufficiently hardy North. November and December.

BEN DAVIS-Tree thrifty, upright grower of almost perfect shape. Fruit large, round, sometimes variable in form; surface smooth, often polished yellow, covered and splashed bright red; flesh white, tender, juicy, flavor subacid, not rich quality; only good for market and cooking. November to spring.

BISMARK-Hardy, and productive; is doing wel. in nearly all places. Fruit large, yellow, shaded

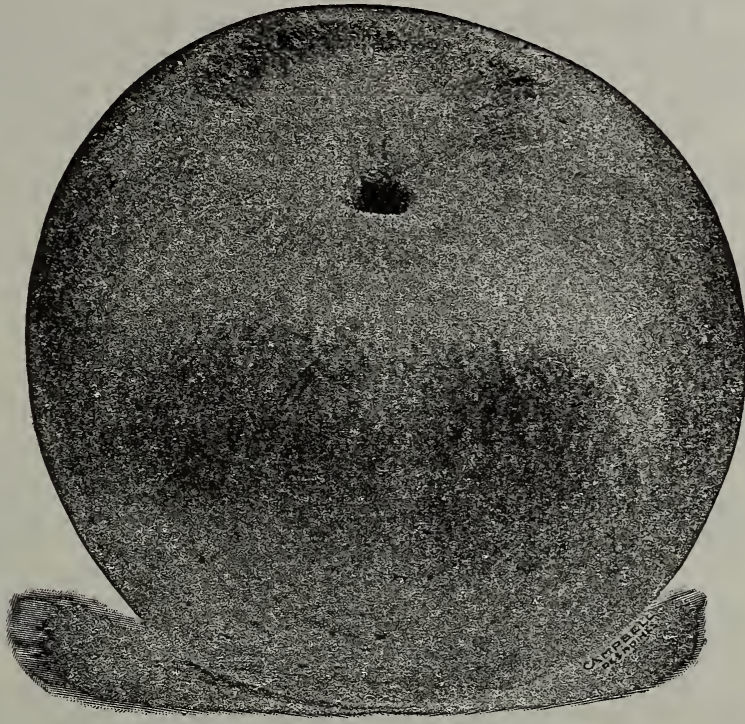

BALDWIN and covered with red; tender, subacid, quality not best, good for cooking. Its most remarkable characteristic is its early fruiting habit; one-year grafts have produced fine specimens and two-year trees seldom fail to produce fruit. Late fall and early winter.

BLACK ANNETTE-Medium, very dark red; mild sub-acid; spicy, good. This has proved one of the hardiest and best winter apples. February.

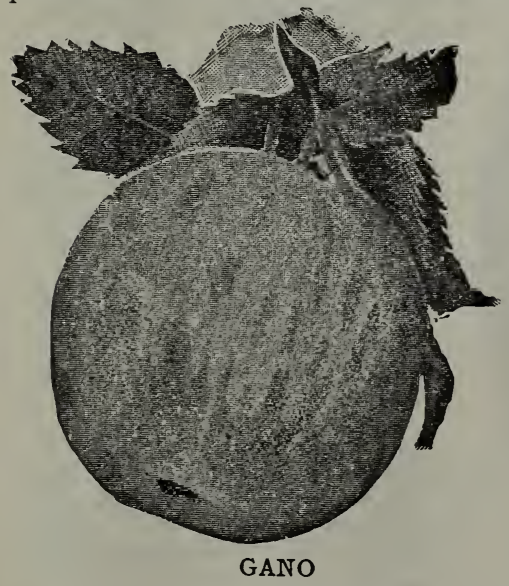

GANO-Fruit is bright red on yellow ground, with no stripes; large, oblong, surface smooth, polished; dots minute; basin shallow, sometimes deep; eye large, cavity deep; brown in color; stem medium to long; core medium. Tree healthy, vigorous and prolific bearer. January to April.

GRIMES GOLDEN-This is one of the most popular apples in cultivation. Tree strong, thrifty grower. Fruit medium or above, cylindrical; regular surface, yellow veined, russeted; flesh yellow, firm, very fine grained, juicy; flavor sub-acid; quality rich. For dessert, cooking and market. November and December.

INGRAM - Seedling of the Rawl Janet. A very late keeping apple. Fruit medium, conical; red and striped; good quality and handsome. Good, healthy tree. Bears young and abundantly. A coming commercial variety. December to spring.

IOWA BLUSH-Medium or less; quality only fair; tart flavor. Tree extremely vigorous and hardy. November to February.

JONATHAN-Tree of rather slender growth and spreading habit; fruit medium or above in size, round or oblong; surface very smooth, waxy yellow, often wholly covered with brilliant red; flesh whitish yellow, tender, very juicy; for dessert and cooking; quality best. October and November. 
KING-Large and handsome, striped red and yellow, tree vigorous and productive. November and December.

LANSINGBURG-Tree upright, spreading and productive; fruit medium, roundish, oblate, yellow, largely overspread with grayish red, flesh firm, mild, sub-acid; good; valuable mainly for its long keeping qualities; vigorous. January to June.

LONGFIELD-One of the imported Russian varieties; a free, upright grower, early and abundant bearer, fruit medium to large, yellowish green, thickly covered with red stripes; a decided blush on the sunny side; rich, sprightly, sub-acid. December to March.

MALINDA-This fine late keeper has flourished and borne fruit in Minnesota and northern Iowa for more than twenty years, and has proven hardier than any other long keeper. Fruit medium, conical, yellow, fine-grained and nearly sweet.

MAMMOTH BLACK TWIG-It is one of the most valuable and profitable apples grown. It resembles in every way the Wine Sap, of which it is no doubt a sport, except that it is one-third to one-half larger. The trees are also the same in habit of growth, color of bark and foliage, but the Black Twig is the stronger grower, and makes a handsome tree in the nursery and orchard.

MANN-Tree a strong, upright grower; fruit medium to large, roundish, oblate, skin deep yellow when fully ripe, often with a shade of brownish red; flesh yellowish, half tender, juicy, mild, pleasant, sub-acid, good to very good. An early and annual bearer.

MINKLER-Fruit medium, roundish oblate, slightly conical, pale greenish yellow, striped and splashed with two shades of red, flesh yellowish, compact, moderately juicy, mild, pleasant, sub-acid; tree an irregular grower, vigorous. January to April.

MISSOURI PIPPIN-Large, oblong, bright red, with numerous gray dots; very handsome and of fair quality; an early and very abundant bearer and a very profitable orchard fruit; vigorous. December to March.

NORTHWESTERN GREENING-Fruit medium to large, averaging from seven to eight ounces each and very uniform in size. Color greenish yellow, flesh juicy, firm and fine grained. Very fine quality and flavor. Tree is very hardy and a thrifty grower, an early and continuous bearer. One of the longest keepers known. January to spring.

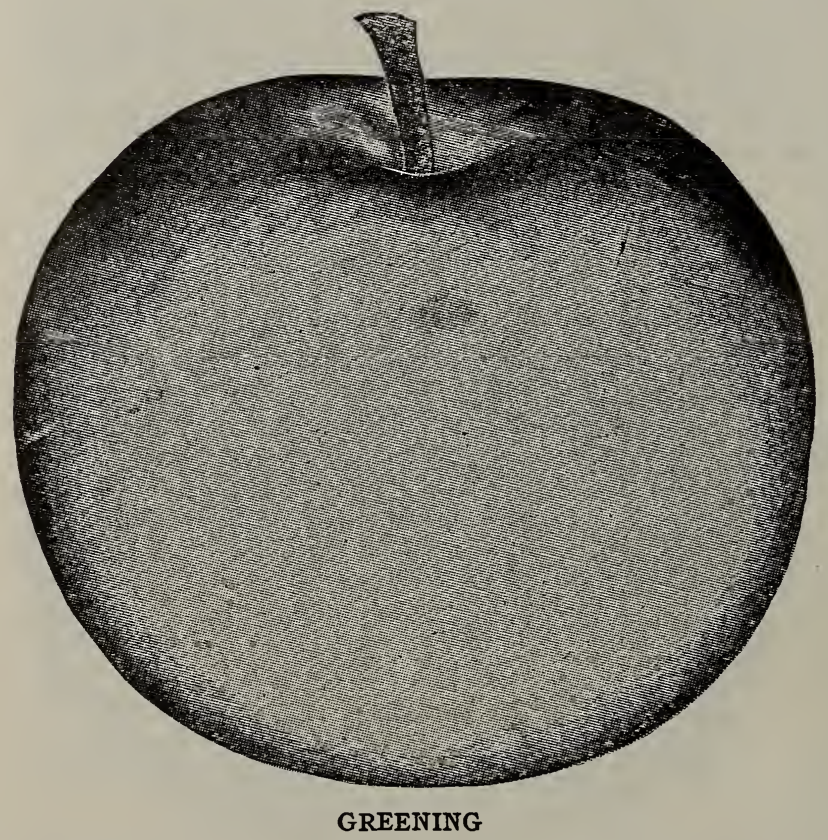

PATTEN GREENINGDuchess seedling, originated by C. G. Patten, of Iowa. Good size; flavor pleasant, sprightly, sub-acid. Superior for cooking. December to February.

PEWAUKEE-A seedling of Oldenburg. Medium to large, roundish, oblate; skin brightish yellow, striped and splashed with dark red, and overspread with whitish dots; flesh white, tender, sub-acid, quality fair; tree vigorous, extremely hardy, especially for cold and severe climates, one of the iron clads. January to May.

PRICES' S W E E T - A large greenish, yellow, flatshaped. Apple claimed by many to be superior to Talman Sweet. Tree hardy and productive.

RAWL JANET-Tree good grower, not so large as some; fruit medium; somewhat conical, regular; surface smooth, mixed and striped on yellow and green; flesh yellowish, crisp, fine grained, juicy; flavor sub-acid; quality good to very good. For dessert, kitchen, market and cider. November to spring. 
RHODE ISLAND GREENING-Large, greenish yellow, tender, juicy and rich, with rather an acid flavor; growing strong and spreading, and an abundant bearer, but drops prematurely at the West, and should be gathered early if planted at all. November and December.

ROMAN STEM-Tree moderate grower and productive; fruit medium, globular; surface smooth, yellow, sometimes blushed; flesh yellowish white, fine grained and juicy; flavor mild sub-acid; quality very good; for table use. October to December.

ROME BEAUTY-(Gillett's Seedling.) Large, yellow, striped with red, flesh juicy, crisp, sub-acid, tree moderate grower. October to December.

RUSSET-Medium to large, greenish or yellow russet, crisp, good sub-acid flavor, productive, very popular on account of its long keeping; vigorous. December to May.

SALOME-Fruit of medium and uniform size; quality very good; early and annual bearer. Tree a strong grower and hardy.

SCOTT WINTER-Extra hardy, sour, red striped. A valuable variety, hardy; thrifty grower, bears young. Fruit medium size, roundish; surface deep red and light red in blotches and streaks. Flesh yellowish white, slightly reddened near the skin; rather acid and good in quality.

SNOW-See description of "Fameuse."

SUTTON BEAUTY-Fruit medium to large, roundish, skin waxen yellow, striped with crimson; flesh whitish, tender, sub-acid, quality very good; tree a free, handsome grower and productive; flesh tender and juicy, good color and keeps late.

TALMAN SWEET-Medium size, pale yellow, slightly tinged with red; firm, rich and sweet; excellent for preserving; tree vigorous, very hardy and productive. November to April.

WAGENER-Medium to large, deep red in the sun, flesh firm, sub-acid and excellent, very productive, bears very young. October to December.

WALBRIDGE-Medium size; handsome, pale yellow, striped with red; crisp, a late keeper; tree very vigorous, extremely hardy. January to May.

WILLOW TWIG-Large, roundish; greenish yellow, striped with dull red; flesh firm, rather coarse; pleasant sub-tart flavor; fine for cooking.

WINE SAP-Large, roundish; deep red; medium quality; keeps well; tree a fair grower and good bearer. December to May.

WINTER BANANA-A new variety that gives promise of being a highly prized and valuable market sort. Beautiful yellow fruit; flavor exquisite and very tempting; highest quality. Productive. Reliable growers represent it to be hardy North.

YORK IMPERIAL - Tree moderate grower and productive, fruit large, lop-sided; surface smooth; color mixed bright red on yellow ground; flesh yellowish, tender, juicy, flavor mild sub-acid; quality very good; for market, table, kitchen. November till spring.

\section{CRAB APPLES}

The improvements in the varieties of crab apple have kept pace with other kinds of fruit. A few years ago it was thought fit only for cider, preserves and jelly, but there are varieties now that command a good price on the market for dessert purposes; especially is this the case with the Whitney. Ornamental when in bloom and when loaded with their highly colored fruits.

They are entirely hardy, and do well in any kind of soil, in the most exposed situations.

They come into bearing very early, generally the second year, and bear every year.

They are unequalled for jelly, and can be dried, cooked, canned and preserved with the skin on, thus saving work.

BRIAR SWEET-A strong growing, fine orchard tree; an abundant bearer. Fruit pale yellow splashed with carmine; rich and sweet with little or no crab flavor. Season, September. 
September.

FLORENCE-Large, handsome; crimson, splashed with darker red; prolific, valuable.

GENERAL GRANT - Large, roundish oblate; yellow, with stripes of deep red, and dark red, almost black on the sunny exposures; flesh white, moderately fine grained, mild, sub-acid flavor. September and October.

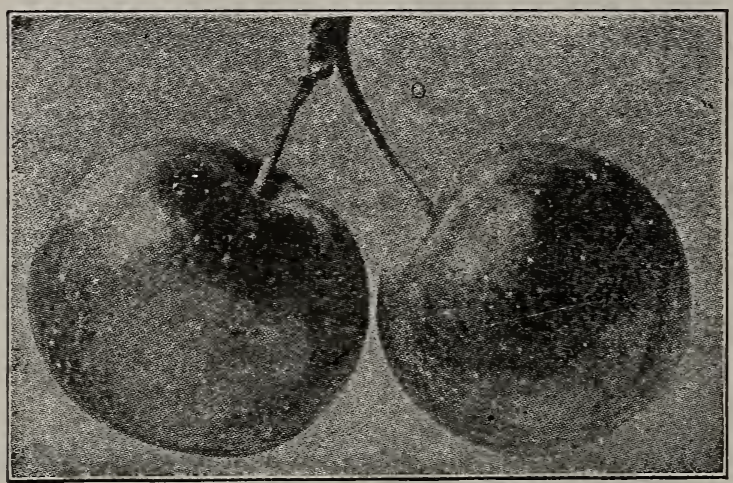

HYSLOP

HYSLOP-Tree a moderate grower, making a beautiful shaped, thrifty tree; bears young; fruit large, nearly round, flattened at the ends; skin smooth, color dark rich red on yellow ground; flavor very good.

MARTHA-This is one of the best. The ground is bright yellow, nearly over-spread with light bright red. Of good size.

QUAKER BEAUTY-T $\mathrm{r}$ e e one of the strongest growers, good bearer; quality good. October to January.

SOULARD - An improved native of high quality. Fruit very large, yellowish when fully ripe. Partakes strongly of the wild flavor. Perfectly hardy.

TRANSCENDENT-A very strong grower, making a large, beautiful tree; an early and abundant bearer, fruit large, round, skin smooth, color rich yellow, shaded with red. August and September.

WHITNEY NO. 20-Tree thrifty, upright grower; fruit large, skin smooth, striped and splashed with carmine; flesh firm, juicy, of pleasant flavor. One of the very best. August.

\section{Pears}

The pear succeeds on most soils, but does best on rather heavy loam. Budded on its own stock it makes what is called a standard tree; but on quince stock it makes a dwarf. Standards are bcst adapted to large, permanent orchards, but dwarfs come into bearing very much sooner and may be planted much closer together. Dwarfs must always be planted sufficiently deep to cover the quince stock two or three inches.

The soil should be rich and well cultivated. A pear orchard should not be permitted to "go to grass." They should be pruned every year, dwarfs especially. Dwarfs should have low heads and be irained in a pyramidal form, one-half of the previous season's growth being cut off each spring.

Pears succeed best on rather steep hillsides. Plant Pears midway of the slope, putting something else on the upper and lower sections. Cultivate sparingly, so as to induce a very slow growth, and let blue grass take the land before the trees come into fruitage. When blight appears, cut off the affected parts at once and burn them; cut six inches below the lowest blight, to insure taking all infected sap.

GATHERING PEARS-Don't let them ripen on the trees, where they rapidly lose their flavor. Gather the early Pears as soon as the fruit readily parts from the branch, and the later varieties should be gathered two weeks before fully ripe. Ripen the fruit in the house in a dark room. Thin the fruit when the trees are heavily burdened, especially the young trees.

Choose a dry soil (clay or heavy loam is best), a sheltered situation, low-headed trees, cut back straggling shoots one-half every spring to compel dense crops, mulch well winter and summer. 
KOONCE-Medium to large, very handsome; yellow, one side covered with bright red; flesh juicy, sweet, spicy, good; very earliest. Trees very vigorous, hardy and productive. August.

BARTLETT-Large size, with often a beautiful blush next to the sun; buttery, very juicy and high flavored; bears early. August and September.

CLAPP'S FAVORITE-Large obovate, ovate; skin thin, pale yellow, marked with pale crimson and fawn colored dots; flesh white, fine grained, juicy, buttery, rich, melting and sweet. Very vigorous, upright grower. August and early September.

EARLY HARVEST-Vigorous and long lived. The fruit is large golden yellow with a fine red cheek, flavor poor, but it sells well in market because of its size and earliness in ripening.

M A N N I N G ELIZABETHMedium; yellow, red cheek; juicy, melting. No other pear less subject to blight.

WILDER EARLY-One of the very earliest pears. Size medium, greenish yellow, with a brownish red cheek and numerous dots; flesh white, fine grained melting, excellent. Always find a ready sale in market. Largely grown by commercial orchardists. Tree bears good crops early and annually. D. and S.

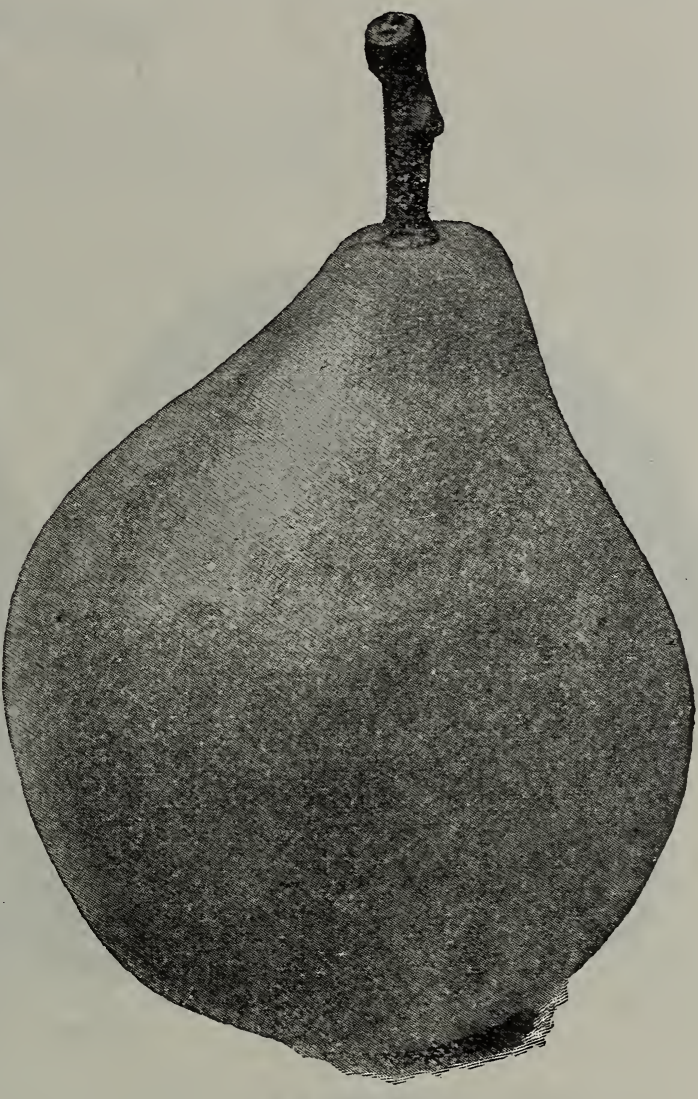

BARTLETT

\section{AUTUMN PEARS}

BEURRE D'ANJOU-Large, obtuse, pryaform; dull, yellowish green, sometimes with a dull, reddish cheek; flesh whitish, juicy, melting, with a brisk perfumed flavor. Vigorous and hardy. October.

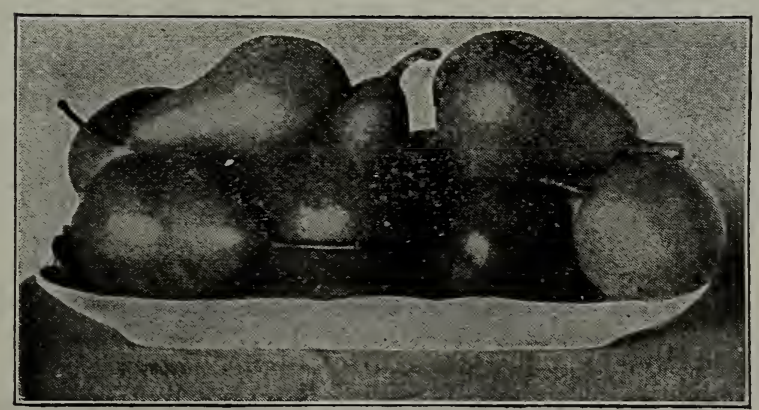

CLAPP'S FAVORITE
DUCHESS D'ANGOULEME -Very large, oblong, obovate, dull greenish yellow, flesh white, very juicy, buttery, with a rich, excellent flavor. Tree a strong grower. October.

FLEMISH BEAUTY-Large beautiful, juicy, melting, rich and fine; good bearer; one of the hardiest and does well nearly everywhere. September and October. 


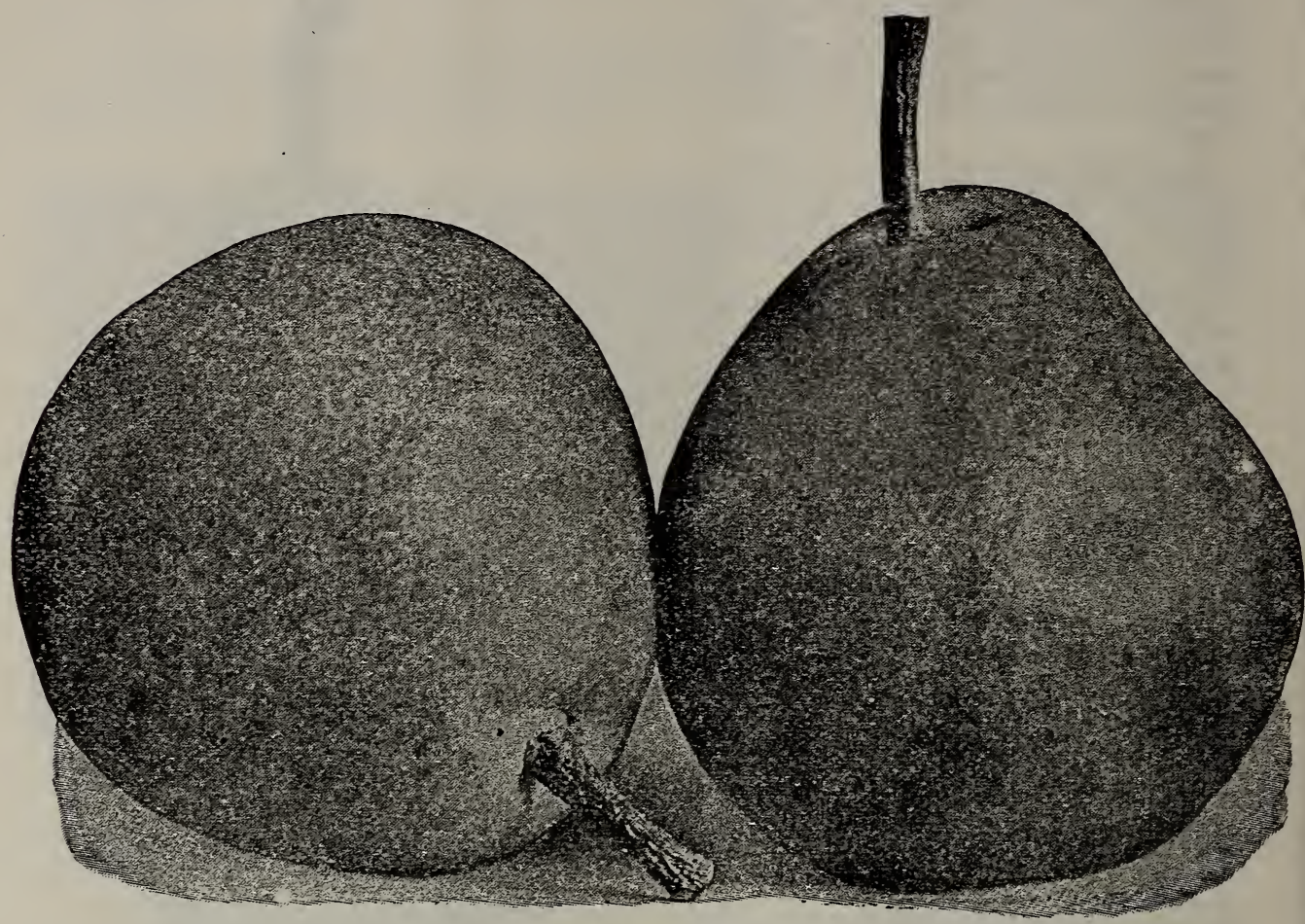

KIEFFER PEARS

GARBER HYBRID-Ver y large, oval, narrowing at both ends; yellow as an orange; flesh whitish, juicy, sweet and very pleasant. Tree an upright grower with heavy, dark green foliage. Saptember.

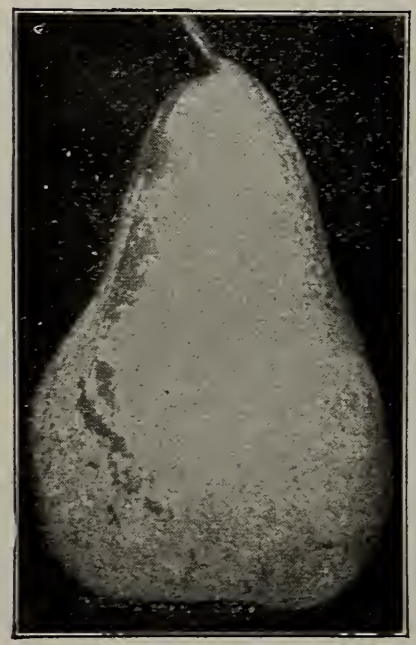

HOWELL-Large, light yellow, red-cheeked; rich and sweet. Tree upright, free grower; early and prolific September and October.

IDAHO-A native of Idaho. Fruit golden yellow, with red cheek. Shaped more like an oblong apple than a pear. Delicious flavor. October to December.

KIEFFER-Large; golden yellow, often blushed in the sun; juicy and melting. One of the best for canning and preserving; the most profitable to grow. Tree healthy, hardy and vigorous. Does not succeed on quince, therefore no dwarfs should be planted. Kieffer receives more praise and condemnation than any other. It seems to be losing favor in some regions on account of its low quality. It is liable to overbear, therefore special pains should be taken to thin the fruit.

LINCOLN CORELESS-Practically coreless; very late. Fruit should be picked when green to escape the early frosts. Large; quality good. Good bearer, fairly hardy.

SECKEL-Small, skin rich, yellowish brown; flesh very fine grained; sweet, juicy and pleasant. Best for its size. September and October. 


\section{Plums}

The plum delights in a cool, not too dry situation, and good, rich soil. Plant in rows north and south with trees 10 to 15 feet apart, in rows far enough from each other to give good air circulation. The varieties we offer have been thoroughly tested, and are standbys. These may be relied upon to furnish yearly crops of this most highly profitable and exceedingly delicious fruit.

The only serious difficulty is that many of the best sorts are not self-fertile and though blooming abundantly, they must have the compcny of other varieties to enable them to mature fruit. Therefore, be sure to plant several varieties together, so tha; every tree has a different variety for its next door neighbor. Use Hawkeye and DeSoto for fertilizers.

DISEASES AND ENEMIES OF THE PLUM-The prevalence of the disease of the plum commonly known as the "Black Knot," which has so much discouraged people in the eastern states from giving to the plum its merited share of attention, has as yet done but little damage west of the Mississippi River, but its appearance should be guarded against, and its ravages prevented by keeping the trees in healthy condition, which is done by good cultivation, and removing the Knot by a mputation on its first appearance. Nothing is more favorable to the growth of the black fungus or knot than neglect. But the great enemy of the plum is the insect known as the Curculio, a small, dark brown beetle which punctures the fruit in depositing its egg from which is hatched the destructive grub, and causing the fruit to drop prematurely and rot. Two ways of destroying this Curculio and saving the crop of fruit is recommended, viz:

First. Spread a large sheet prepared for the purpose under the tree and then jar the tree so as to shake down all fruits that have been stung, as well as all the curculios; both insect and stung fruit are destroyed. Begin to do this as soon as the blossom falls, and keep it up daily, or at least tri-weekly until the fruit is half grown. The morning is the best time to do this when the insect is chilled and stupid.

Second. The best remedy and the one generally adopted now doubtless is the spraying of the trees, directions for which is given in the last pages of this catalogue. If those who really desire to grow fine crops of this most delicious fruit will try either of these systems and follow it up rigidly they will be successful.

\section{EUROPEAN PLUMS}

BRADSHAW - Fruit very large; dark violet red; flesh yellowish green; juicy ^nd pleasant; productive. Vigorc us. Middle of August.

GERMAN PRUNE--Very large, long, oval; purple, with a thick blue bloom; flesh green, firm, sweet, pleasant and separates freely from the stone. Tree bears enormous crops, hanging late; vigorous. September.

LOMBARD-Tree vigorous, hardy and productive; fruit of medium size, roundish oval, slightly flattenea at the ends; skin a delicate violet-red, paler in shade; flesh deep yellow, juicy and pleasant. August.

SHIPPER'S PRIDE-Size large; color dark purple; flesh firm and excellent. September.

SHROPSHIRE DAMSON-A plum of fine quality. The flesh is amber colored, juicy and sprightly. Very productive and a valuable market variety. Freestone. September.

TATGE-"King of All Plums"The most productive long lived plum known. This fine hardy plum, of European strain, is from a seedling originated in Iowa. A fine grower and an early and profuse bearer. It has stood all the test winters of the past fifteen years and seems to be the most

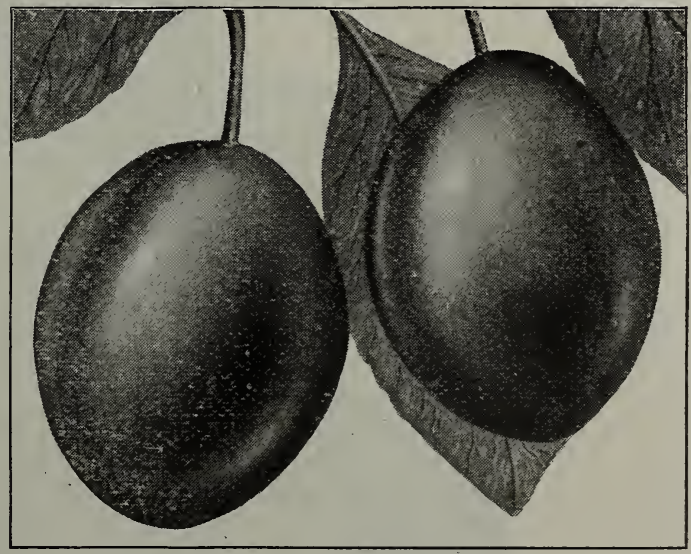
productive long lived plum known. Excellent in quality.

YELLOW EGG-Very large; egg-shaped; excellent for cooking; good and productive; vigorous. Last of August. Splendid variety for nearby market, 


\section{NATIVE PLUMS}

BRIT ILEWOOD-Originated with Theo. Williams, Benson, Neb., from seed of Harrison's peach pollinated with Quaker. Form oval-round; size large, cavity shallow, apex rounded; surface smooth, but not glossy; color dark red, dots numerous, small; bloom thick, grayish; skin thick, slightly astringent; flesh firm, meaty; quality good; stone large, flat, partly free; flavor sharp acid. Tree large, spreading and vigorous.

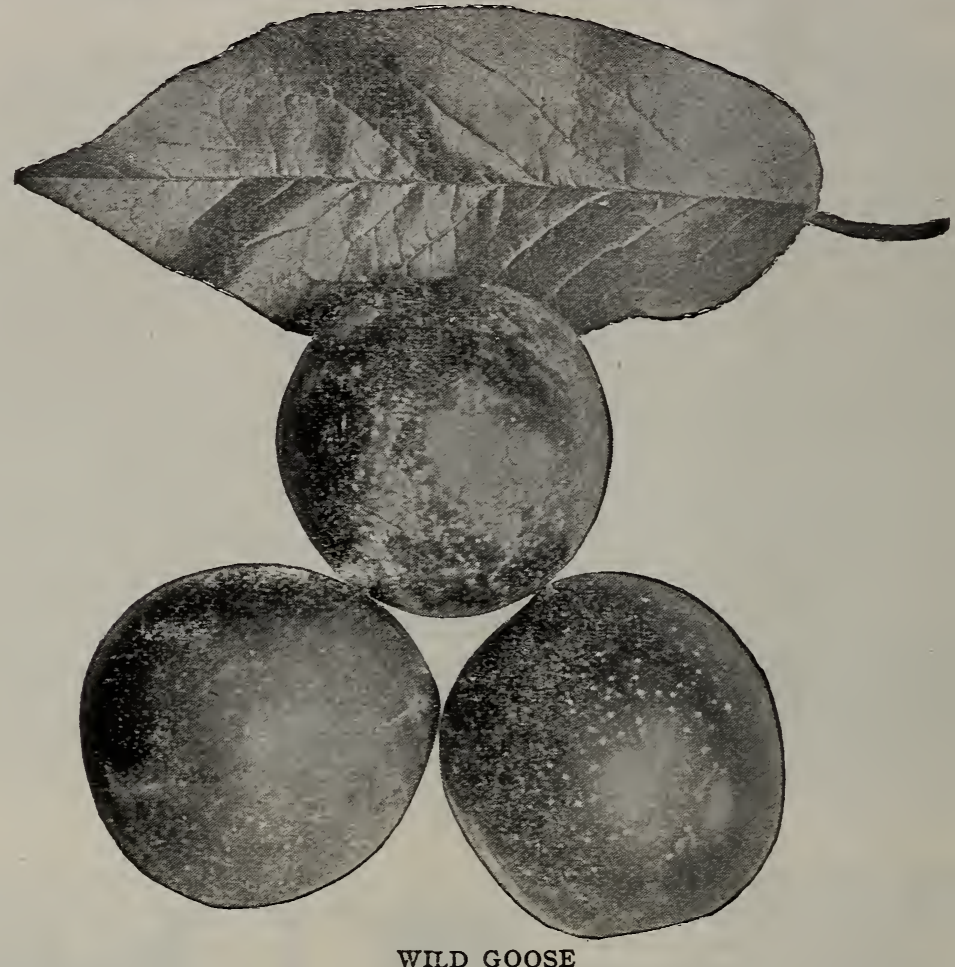

CHARLES DOWNING-Fruit of large size and fine quality. Brilliant red; quality superlative for eating fresh or for kitchen use. The tree is spreading, handsome and fruitful. Hawkeye is an excellent fertilizer for it. Midseason.

DE SOTO-Resembles Miner in form and color, but two weeks earlier. Fine for eating or canning. Tree a moderate grower; bears young and profusely; hardy north. Is best planted on moist rich ground and the fruit thinned. Use this variety for fertilizing.

FOREST GARDEN-A strong growing tree; needs a little attention to keep tree in shape to avoid splitting and breaking of limbs. A profuse bearer and perfectly hardy; nearly round, mottled red and yellow, rich and sweet. August.

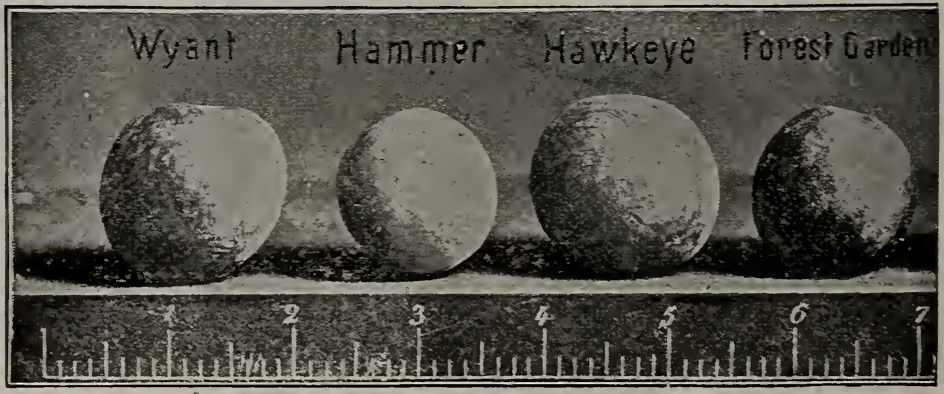


HAMMER - Large, oblong, light red, of fine quality; profusely fruitful; season late; fine for canning or market. The tree is as handsome as any plum tree that grows.

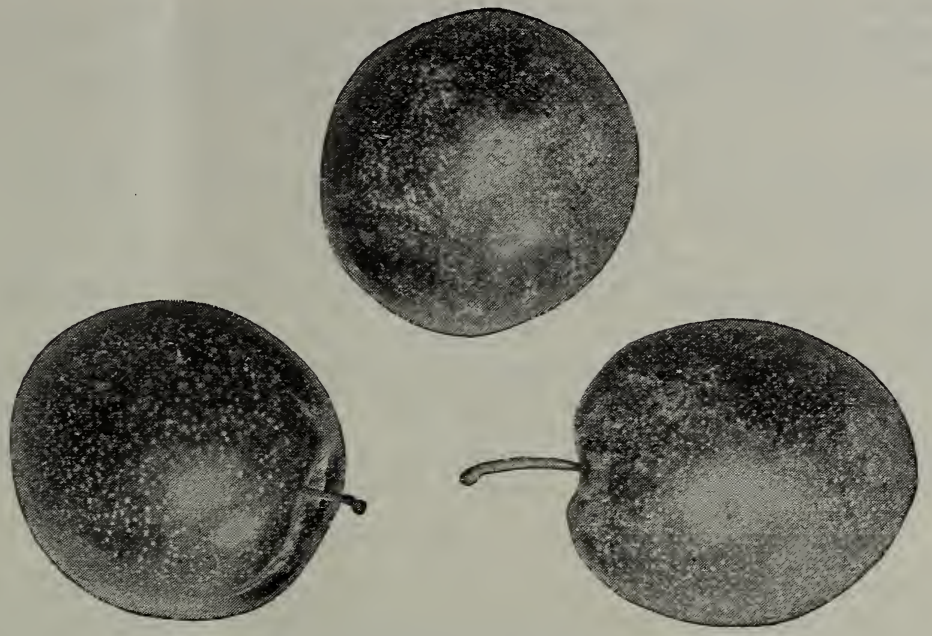

MILTON PLUMS

HAWKEYE--Ona of the best. Large, color light mottled red, superior quality, firm; carries well to market. Tree hardy, thrifty; annual bearer. A splendid fertilizer. September.

MILTON-Medium size, dark red, skin thin, flesh firm, quality fair. Ripens earlier than Wild Goose. Its extreme earliness makes it valuable. A strong grower, productive.

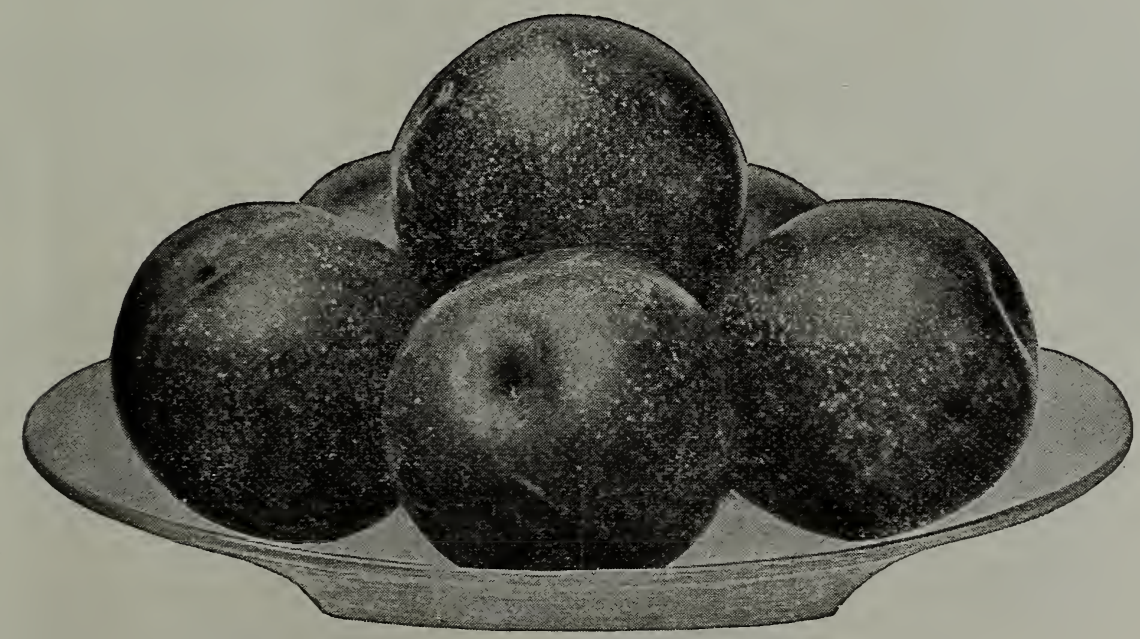

MINER PLUMS

MINER-Tree a strong vigorous grower, fruit large, and of a good quality, A valuable variety to raise in the southern part of the country. Middle to last of September.

POTTAWATTAMIE-Tree a good grower, hardy; color a yellowish red turning to bright red when fully ripe; skin thin, clear and tough. First fruit begins to ripen late in July; quality fairly good. 
STODDARD-One of the largest of the native plums originated in Iowa. It is a light pinkish red color, very handsome, with a tough, sweet skin. Quality fair.

SURPRISE-Grown from seed in Brown County, Minn., in 1886. Professor Cranefield, of Madison, Wis., says: "The very best Plum so far tested in our orchard." Fruit prune-shaped, dark red. Long keeper, therefore valuable for market. Ripe from September 1 to 10 . Tree a thrifty, upright grower; hardy and productive. A fine tree in orchard.

WEAVER-Large, purple with a blue bloom, very prolific; a constant and regular bearer and of good quality. Tree very hardy. August.

WILD GOOSE-The most popular fruit with some fruit growers. Tree a vigorous, upright grower; fruit medium to_large, rich golden yellow, shaded with red; flesh yellow and juicy; flavor rich and good.

WOLF-Fruit large, a perfect freestone. As to quality we find them superb for cooking and for serving with sugar as we use peaches. Tree a good grower; hardy. August.

WYANT-Large, round, oblong, wedge shape, dark red; skin thick; peels readily; flesh firm; freestone, and of excellent quality. Native of Iowa and hardy.

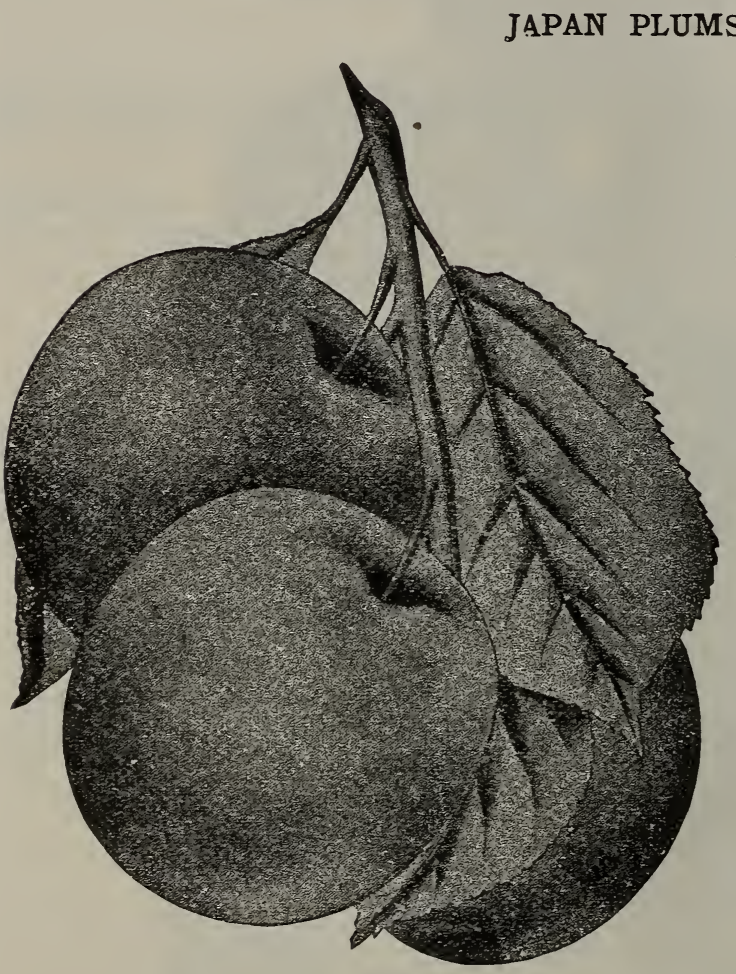

BURBANK

A B U N D A N C E-L $\varepsilon$; g e roundish; freestone; amber,turning to a rich cherry color with a whitish bloom; flesh light yellow, juicy, tender, sweet and excellent, vigorous and very productive. August.

BURBANK-Large, nearly globular; clear cherry red with thin lilac bloom; flesh deep, yellow; rich, very sweet, with a peculiar and agreeable flavor. Vigorous and a very early bearer. Last of August.

KELSEY-Fruit very large, heart shaped; color a rich yellow nearly overspread with a bright red with a lovely bloom; flesh firm, meaty, rich of excellent quality; tree a fair grower. August and September.

SATSUMA (Blood)-A fine large plum, delicious for canning and a grand market sort; nearly round; the flesh is solid, of purplish crimson color from pit to

skin, juicy and of fine quality; pit exceedingly small-very little larger than a cherry stone; tree a strong, vigorous grower with a brownish-red bark and lancelot foliage. Will keep for from one to three weeks after picking. Yields well.

WICKSON-New. A remarkable handsome, very large, deep maroon red plum. 


\section{Select Cherries}

Cherry trees are now generally propagated by budding on Mahaleb stocks, since they do not sprout from the roots. They should be planted deep enough to place the point of union from four to six inches below the surface.

No home orchard is complete without its proportion of Cherry trees, and it is one of the most profitable market fruits and will succeed on any kind of soil that is not wet. There are four groups: Hearst, Bigarreaus, Dukes and Morellos. The sweet cherries, or Heart and Bigarreau varieties, are not so much of a success in the West and Southwest as in the Eastern states, but the Dukes and Morellos succeed everywhere, especially the latter

Northern planters should leave the sweet Cherries entirely alone. If you want to experiment with them, get a tree or two with the expectation of losing it before you see the fruit. Eastern and southern planters may safely plant a few for home use, although the Dukes and Morellos are more reliable and the only profitable market sort.

Cherry culture has been a success when proper attention has been given to the selection of varieties and their culture. The hardy, thrifty varieties of the Morello type may be freely planted with confidence of profitable results. The cherry tree should be planted in a naturally dry soil, or the soil should be well drained, so that water may not remain near the roots for any considerable time. The most successful varieties in general cultivation are:

\section{HEART AND BIGARREAU CHERRIES. (Sweet).}

BLACK TARTARIAN-Very large, bright, glossy black; half tender, juicy, rich and fine. Tree a rapid grower and good bearer. Last of June and first of July.

GOVERNOR WOOD-Large; iight yellow and bright red; nearly tender, juicy, sweet, rich and delicious. Tree vigorous and productive. Middle to last of June.

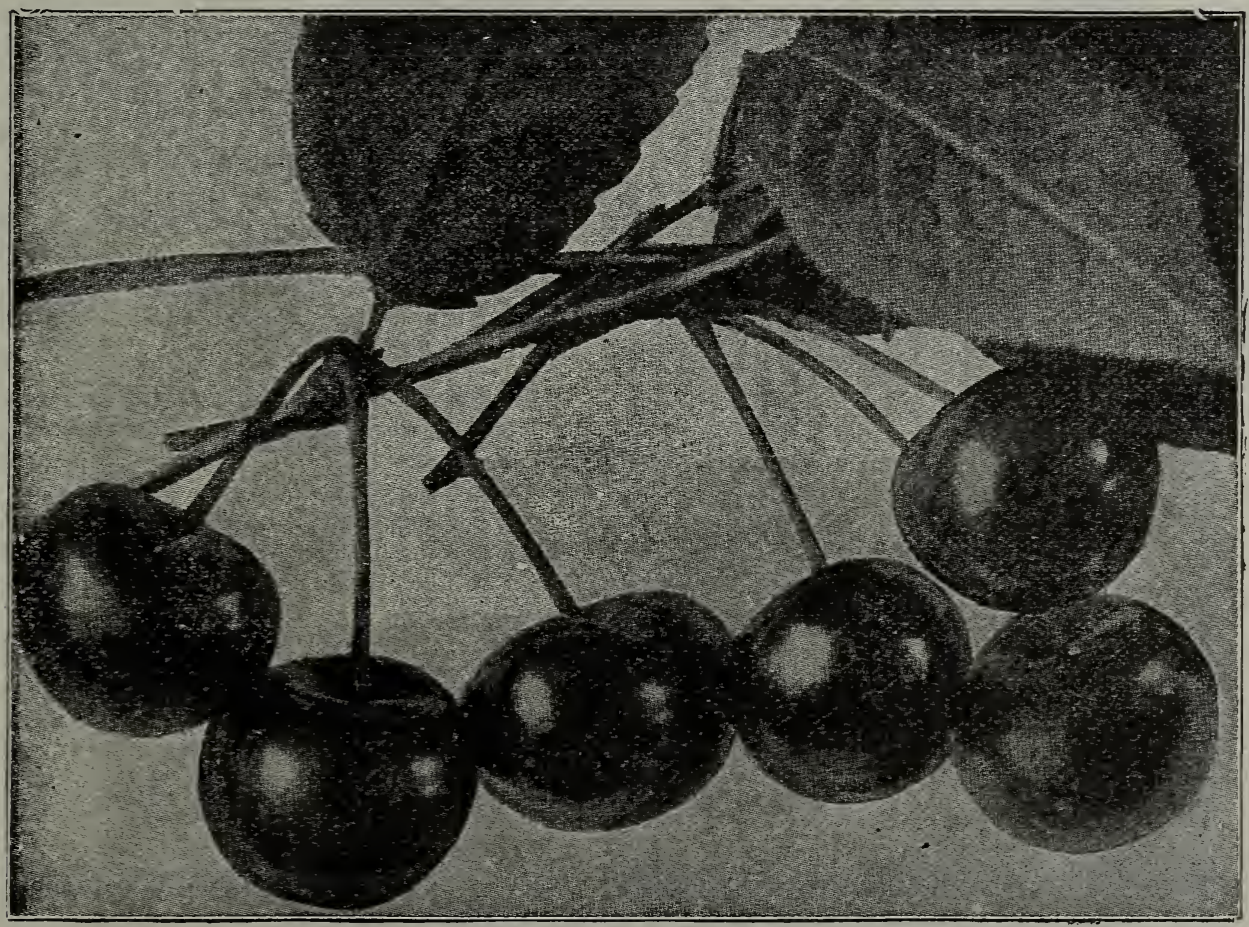

\section{ENGLISH MORELLO CHERRIES}

WINDSOR - The fruit is large, flesh remarkably firm, sweet and of fine quality. Tree hardy and prolific. Middle of June.

YELLOW SPANISH-Large, pale yellow, with red cheek; flesh firm, juicy, delicious and handsome. Last of June and first of July. 


\section{DUKE AND MORELLO CHERRIES (Sour).}

Let Early Richmond and Montmorency make up a large part of your Cherry orchard if you want to be entirely happy. Other varieties are gradually dying out, so that in time Early Richmond and Montmorency, with some English Morelio for late market, will constitute the varieties in the orchard.

These two sorts successfully resist the ailments caused by floods of rain. Professor Webster, of Ohio, reported that these two have so far been able to resist the attacks of the San Jose Scale.

COMPASS-Originated in Minnesota. Is a cross between the Morello cherry and Miner plum. Remarkably hardy and planted extensively in Minnesota and the Dakotas, where encouraging reports have been made as to hardiness and fruitfulness. Its early bearing is wonderful. One year old trees in the nursery now being covered with bloom. Many trees fruit same year they are planted. Unsurpassed in extremely cold climates for canning.

DY EACUSE-This variety partakes both of the Morello and Duke wood and fruit. A very early and sure bearer; ripens a week before Early Richmond, is of better quality and productive. Free. May and June.

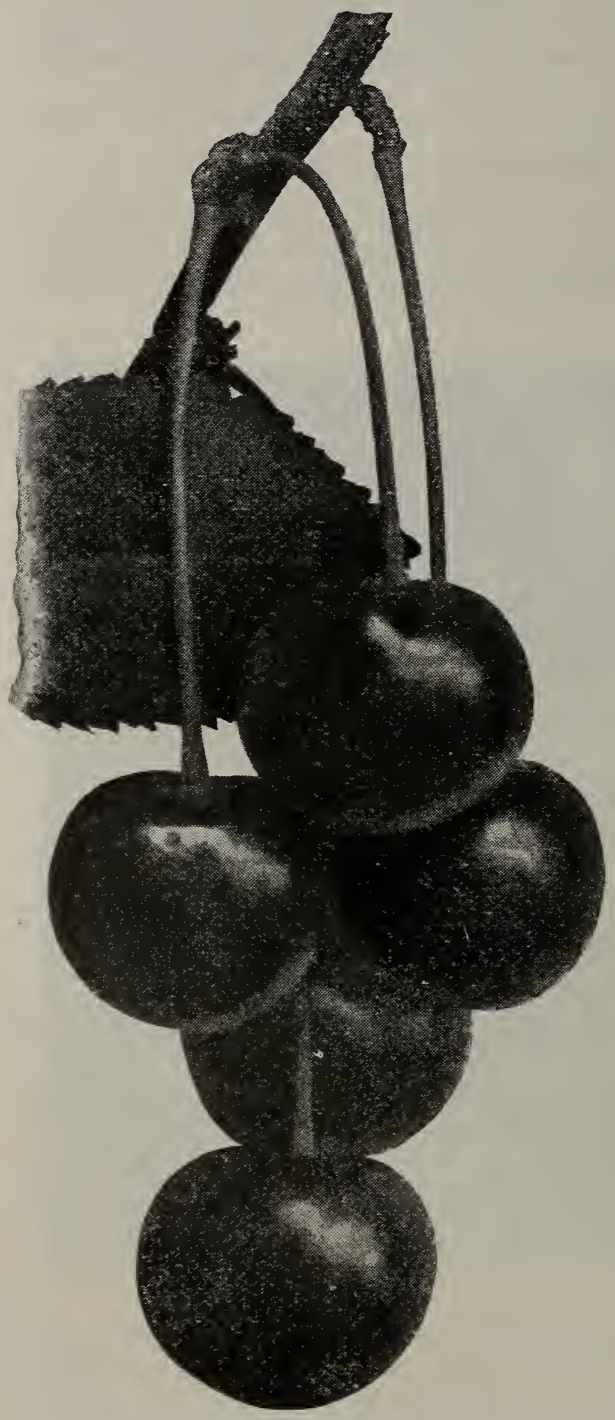

MOITTMORENCY
EARLY RICHMOND - Everywhere the most popular. Tree strong, thrifty grower, making a large, symmetrical head; fruit medium size, dark red, melting, juicy; sprightly acid flavor and especially valuable for cooking purposes; tree an early and abundant bearer. Season last of May and first of June.

ENGLISH MORELLO-Tree moderate grower, hardy; an early and great bearer; the most valuable of the late varieties. Fruit large, round; skin dark red, becoming nearly black when fully ripe; flesh dark red, tender, juicy and of a pleasant subacid flavor when fully ripe. July.

LARGE MONTMORENCY - (Large Montmorency). A fine, large, light red cherry of the Richmond class, but larger and more solid; a more upright grower, equally hardy and productive. Second only to Early Richmond in value. Ripens ten days later.

NORTHWEST - About as large as, and five days earlier than, Early Richmond; dark red; flesh firm. The tree closely resembles Early Richmond in size and general appearance; bears young and abundantly. Charles Downing said: "This is the most valuable cherry for the Northwest."

OSTHEIM-Tree medium size, with round, compact top like English Morello; bears early and abundantly. Fruit medium size; almost black when fully ripe; juicy, rich, almost sweet. For eating from the hand it is at the head of our list of hardy cherries. Season late.

W R A G G - Originated in Iowa. Medium to large in size, long stem, dark purple wh n fully ripe. A variety well adapted for the prairie regions of the Northwest. Appears identical in tree and iruit with English Morello, but is claimed to be a new variety. Valuable late cherry. July. 


\section{Select Peaches}

Peach trees should be planted 16 to 18 feet apart. To secure healthy, vigorous and fruitful trees and fine fruit, the following points should be well attended to:

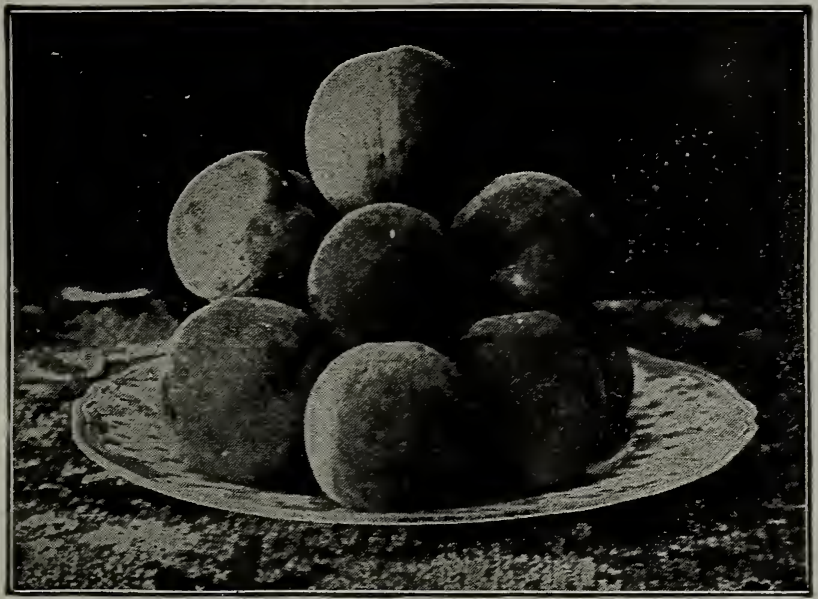

(1) Keep the ground clean and mellow. (2) Keep the heads low, the trunk should not exceed three and onehalf feet in height. (3) Give them an occasional dressing of wood ashes; soapsuds are also good. Prune every spring, shortening the shoots of the previous year's growth. This keeps the head round, full and well furnished with bearing wood. Cut weak shoots back about one-half and strong ones about one-third, but see that there is left a sufficient supply of fruit buds. Sickly and superfluous shoots should be cut out clean. The fruit is borne on wood of last season's growth, hence the necessity of keeping up a good supply of vigorous annual shoots all orcr the trce. Young trees should be well mulched every spring.

ADIIRAL DEWEY - 1 peifect frecstone, of fine size, form and color, with delicious yellow flesh that is yet firm cnough to ship well. The tree is a strong, hardy, symmetrical grower and produces weil. The very best early yellow freestone. July.

ALEXANDER - Large size, handsome and regular in form, with deep maroon shade, covered with tho richest tint cf crimson, rich and good in quality, with a vinous flavor; adheres to the stone. Last of June.

BAILEY-Good size, quality excellent, heavy bearcr, ripens September 1st. By some claimed to be the surest bearer of all the peaches adapted to the Northwest. Freestone.

BANNER-Large, yellow, with crimson cheek, flesh firm, ycllow, rich, excellent; keeps and ships as r.cll as any peach on the market. In growth, early-bearing habit, productiveness and unusual hardiness of wood and bud, the variety is all that could be desired. Has been grown in Canada for fifteen to twenty years and found to produce good crops yearly through several seasons when all other sorts failed. The very best late market variety. October.

CRAWFORD'S EARLY-Fruit very large, oblong; skin yellow, with a fine red cheek; flesh ycllow, juicy, sweet and excellent. Wonderfully productive and hardy. Freestone Last of August.

CRAWFORD'S LATE-Fruit of the largest size; skin yellow or greenish yellow, with dull red cheek; flesh yellow; productive. One of the finest late sorts. Freestone. Last of September.

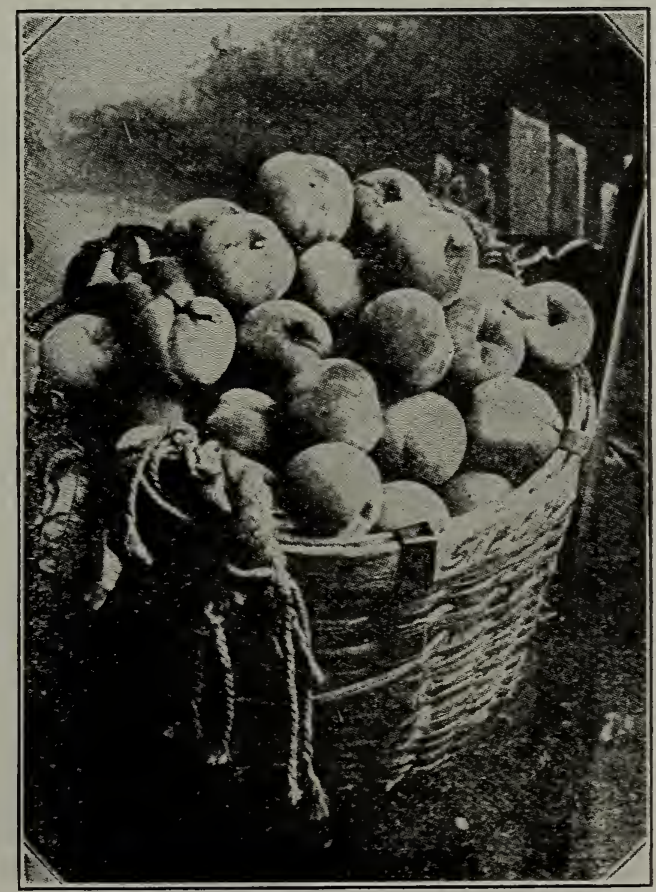

ELBERTA PEACEES 


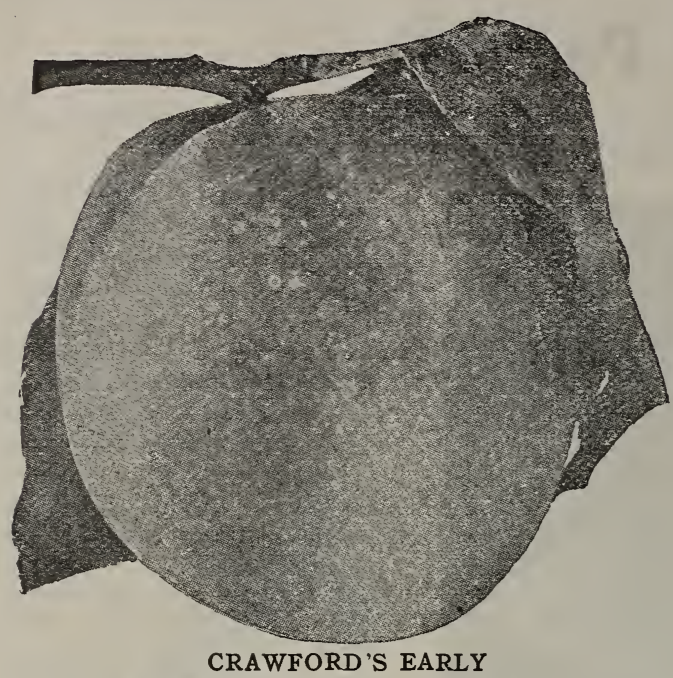

BOKARA-Raised from seed procured in Bokara, Asia. It has been fruited in the Northwest for years and found to be one of the hardiest peaches known there. Tree has stood 28 degrees below zero with but little injury to the tips, and produced fair crops. Fruit large, yellow; with red cheek, of good quality, perfect freestone; skin tough, a fine shipper. August.

CHAMPION-Originated at $\mathrm{Ne}$ koma, I1l. The earliest freestone and a first-class shipper. Eears full crops when other's fail. In comparison with the bountiful yicld of all of the best kinds, it is of all of them the champion. Size large; flavor delicious, juicy, swect, rich, excelling all other varieties; very handsome in appearance, creamy-white with red cheek; very hardy; season carliest.

CROSBY-Medium; rich orange yellow with blush; freestone; pit small. flesh yellow, juicy and sweet. Tree low, spreading; willowy habit of growth. Ripens before Crawford's Late.

ELBERTA-Large yellow with red cheek; of excellent quality; flesh yellow and melting; freestone. Middle of July.

FITZGERALD - An improved Early Crawford, being fully equal to it in size, quality and color. The tree conmences bearing young, is productive and one of the hardiest. Fruit large, brilliant color, bright yellow, suffused with red; flesh deep yellow, best quality. Early September.

HEATH CLING-Large, oblong, white, slightly tinged with red in the sun. Fruit tender, rich, melting, luscious. September 15.

HILL'S CHILI-One of the most hardy varieties known. Dry, firm flesh, sweet and excellent for canning. The fruit is not large, but you will always be sure of peaches if you plant a few trees of Hill's Chili.

MAYFLOWER (The Earliest Red Freestone Peach in the World)-Trees two years old have produced over half a bushel of fruit. A strong grower and perfectly hardy. Fruit large, skin red and crimson, very attractive, fresh bright yellow, excellent flavor and nearly freestone. Good bearer and shipper. No peach orchard complete without the Mayflower.

OLDMIXON-One of the old standard sorts. Strong, upright grower, needing heavy annual shortening. Fruit large, round, somewhat elongated. Flesh firm and of good quality. August.

SNEED - Fruit medium to large, greenish white, blush on sunny side; juicy and good, July. Not reliable North, though desirable as a very early bearer.

STUMP THE WORLD-Large, round; white skin, with red cheek; flesh white, juicy, good. Freestone. August 15.

T R I U M P H-Earliest yellow fleshed peach, with good eating and shipping qualities. Ripens with Alexander, blooms late; sure and abundant bearer; strong, vigorous grower. Fruit good size, yellow, with red and crimson cheek.

WONDERFUL-Originated in New Jersey. Very large, yellow with red cheek; flesh yellow, highly flavored and firm; bright red at the pit, which is small and parts freely from the flesh. Good keeper. October.

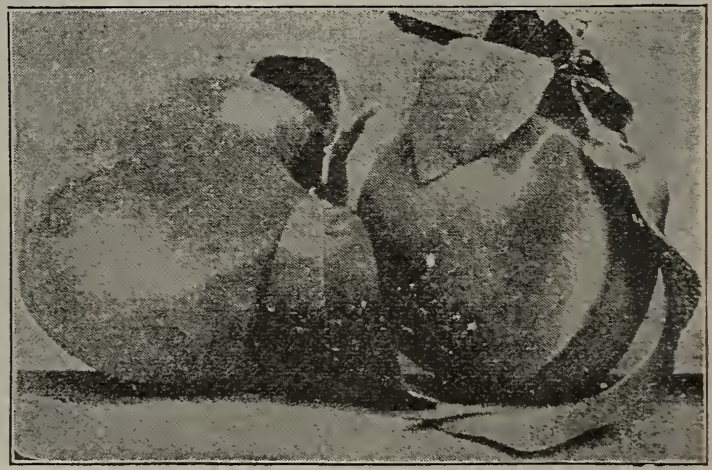

BANNER PEACHES 


\section{Apricots}

If your Apricots are attacked by Curculio, apply the same treatment as given for Domestic plums. Budded on our native plum seedling stocks, they are especially hardy and desirabie.

The Apricots, one of the most beautiful and delicious of fruits, ripening just between cherries and peaches, is of great value south. Plant the trees in among plums.

ALEXANDER-Russian, an immense bearer. Fruit large, oblong, yellow, flecked with red; sweet and delicious.

BUDD-Russian. Large, white with red cheek; sweet and-juicy; strong grower, good bearer. Late.

CHINESE-Vigorous grower. The fruit is barge, yellow with red cheek, of good quality; a freestone.

GIBB-Russian. Medium, yellow, sub-acid, rich and juicy; the best early sort.

EARLY GOLDEN-Small, pale orange; flesh orange, juicy and sweet. Tree hardy and productive. Beginning of July.

HARRIS-Origin, Geneva, N. I'. Recommended for extreme hardiness and good bearing qualities. Large, fair quality. Best market variety.

MOORPARK-One of the largest and finest apricots. Yellow, with red cheek. Flesh orange sweet, juicy and rich; parts from the stone. Very productive.

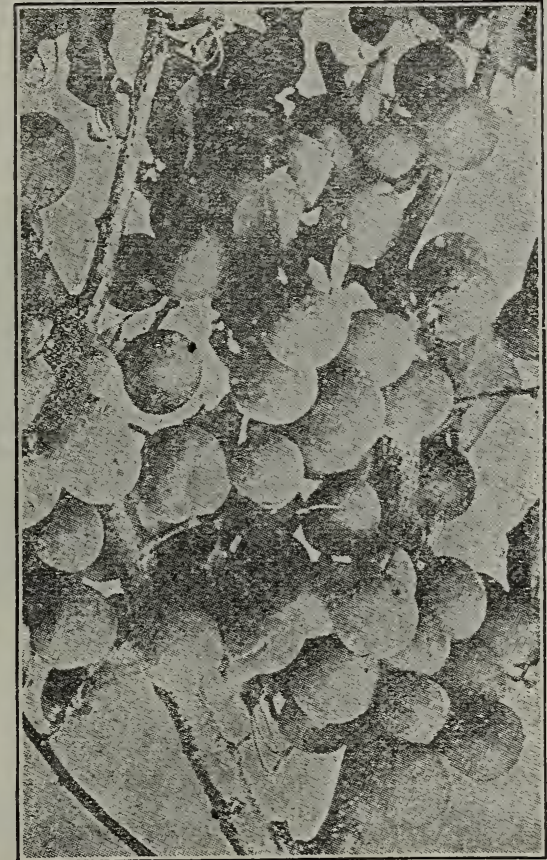

BUDD APRICOT

\section{Quinces}

One of th- ust profitable and attractive market fruits. In places where the right conditions of soil and climate are met, it succeeds well. It wants mellow, well-enriched soil and plenty of moisture. One of the best inodes of cultivation for the Quince is given as follows:

Late in the autumn give the soil a top dressing of potash, or wood ashes, which is the best, though slacked lime or cow manure will do. Sprinkie some salt over the ground and then cover with a heavy mulching of straw or litter, say six or eight inches thick, to prevent the roots from severe freezing, and in the spring remove the mulching, placing it in piles near the trees, and cultivate the soil thoroughly until about the last of June or lirst of July, at wh.ch time replace the mulching, which should again be removed in October and replaced about one month later after the ground has been top dressed as above directed, and continued in this way from year to year.

CHAMPION-Fruit large, fair and handsome. Tree bears abundantly while young. Flesh cooks as tender as an apple and without hard spots or cores; flavor delicate. most valuable of all.

MAMMOTH (Rea's Mammoth)-A very large, fine variety of the Orange type. Strong grower and productive. Brought into notice near Kansas City, Mo. Probably the best of all Quinces.

MEECH PROLIFIC-The most profitable of all known varieties. Ripens between the Orange and the Champion. Bears early, quality good, and size large.

ORANGE-Large, roundish; yellow; cooks tender and is of excellent flavor. Valuable for preserves and flavoring. Productive. September. 


\section{Mulberries}

The mulberry is not only valuable as an ornamental shade tree, but the fruit is well worthy of a place in every collection. Plant in deep, rich sandy loam. The tree requires little or no pruning and is of easy culture.

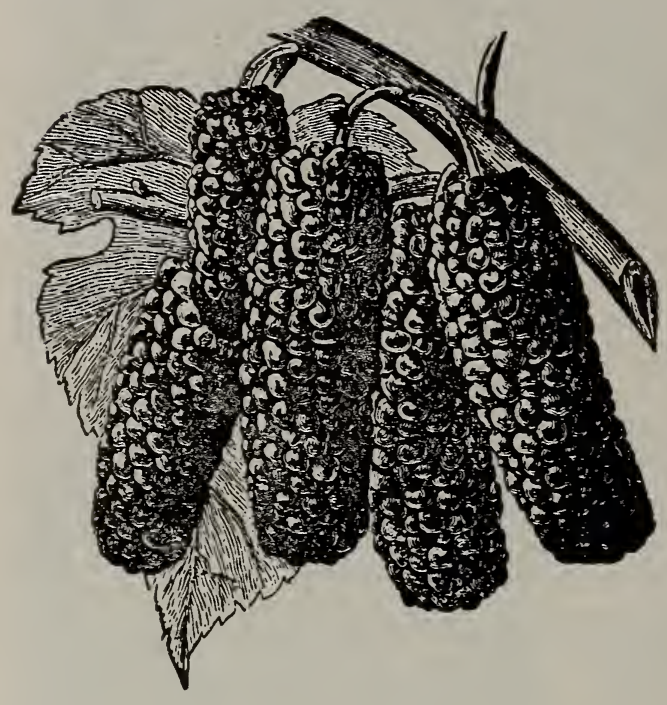

DOWNING'S EVERBEARING MULBERRY

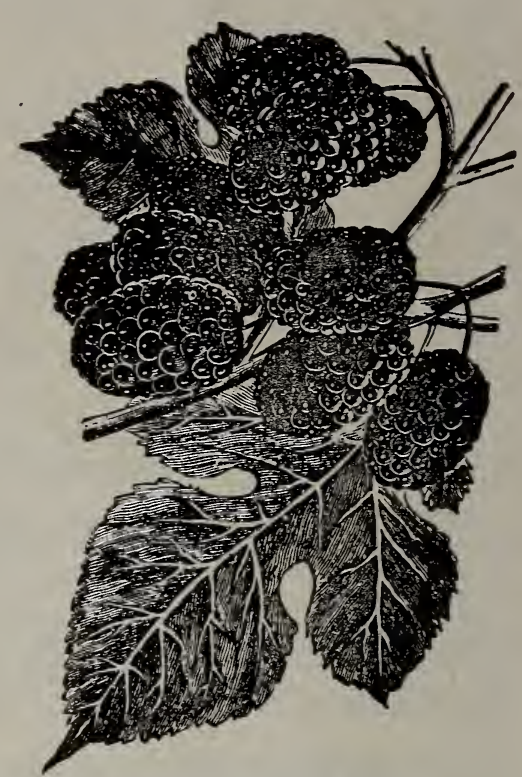

RUSSIAN MULBERRY

DOWNING'S EVERBEARING-This very delicious variety originated from the seed of the Morus Multicaulis, having the strong, vigorous habits of that species and produces a large fruit of a dark, purplish black color; flesh juicy, rich, sprightly, delicious. Very productive and ripening its fruit in succession for a long time. Not hardy North.

NEW AMERICAN-Largest fruit, black; delicious flavor; a very attractive lawn tree, with very large leaves. Of rapid growth. Hardy.

RUSSIAN-Good shade and ornamental tree, growing freely and symmetrically, holding its leaves late in the fall. Very rapid grower, excellent wind and snow break; bears early and constantly. Color of fruit varies some, generally balck; most valuable to supply the native birds, thus keeping them from the most precious fruits.

\section{Select Grapes}

Almost everyone can find room for from six to a dozen or more grape vines. They can be trained up the side of any building or over a garden fence, but the best and cheapest way to grow them either in large or small quantities, is on a wire trellis. Work the ground deep for grape vines and plant a little deeper than they were in the nursery. Make the rows eight feet apart and plant vines six to eight feet apart in the rows. Some of the tender varieties would be benefited by laying the vines flat on the ground during the winter, with a light covering of earth or litter.

PR JNING-Annual and careful pruning is essential to the production of good grapes. The roots rannot !ring to maturity a fine crop of fruit if they are called upon to carry too much wood. Late in the fall is the best time to prune, when the vines are dormant. 


\section{RED GRAPES}

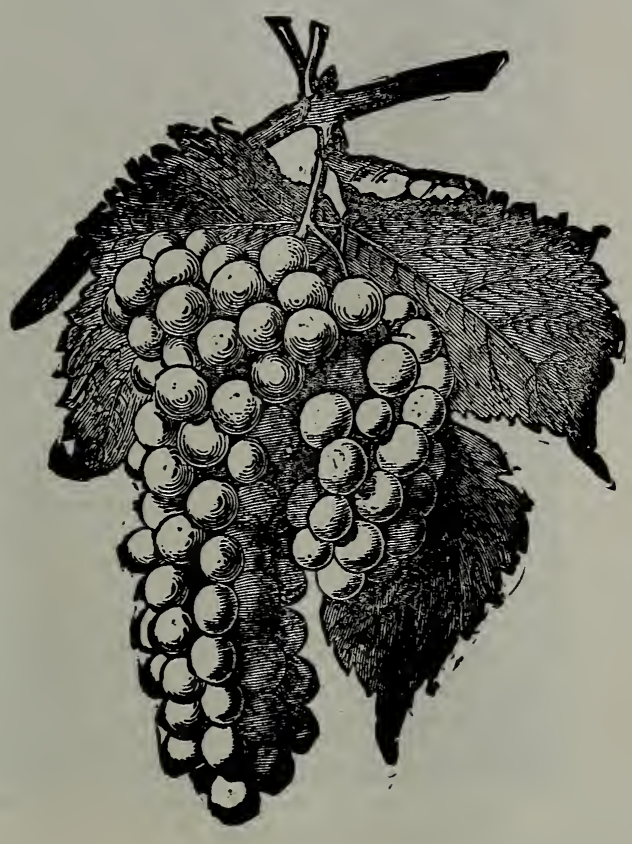

WOODRUFF (RED)

AGAWAM-Bunch large, shouldered; berry large, round, reddish brown, tender, vinous and of excellent flavor. Very vigorous and productive. Vine hardy and one of the best of its class.

BRIGHTON-Bunch large, shouldered; berries medium to large, round, dark red, tender, very little pulp, sweet, juicy, slightly aromatic and very good. Ripens early.

DELAWARE-The bunches are small, compact, and sometimes shouldered; berries are small with thin but firm skin; flesh juicy, very sweet and refreshing and of the best quality for both table use and for wine. Ripens with Concord or a little before; vine is hardy, productive and a moderate grower.

SALEM-Bunch large and compact; berry large, of a light chestnut or Catawba color. thick skin, perfectly free from hard pulp; very sweet and sprightly with a most exquisite aromatic flavor; as early as Worden; keeps well.

WOODRUFF-A handsome, profitable market sort; vine vigorous, productive; ironclad constitution. Bunch and berry large, attractive, ripens early; fair quality, long keeper, good shir per. In most sections the best red market grape for main crop.

\section{BLACK GRAPES}

CAMPBELL'S EARLY-A new, very large and fine early grape, black; strong, vigorous, hardy vine with thick, healthy leaves; clusters very large, usually shouldered, compact and handsome; berries large, nearly round, black, rich, sweet, very good; skin thin; seedsfew and small, parting easily from the pulp; a good shipper. Ripens very early, but remain sound on the vines for many weeks. This makes it one of the most satisfactory and profitable market sorts to grow.

CHAMPION-Bunches large and compact; berries large, covered with a rich bloom; poor in quality; vine a strong and healthy grower and a good bearer; profitable for market on account of its earliness.

CONCORD-One of the most popular and reliable varieties we possess; bunch large, compact and shouldered; berry large, round, almost black with blue bloom, juicy, buttery and very sweet.

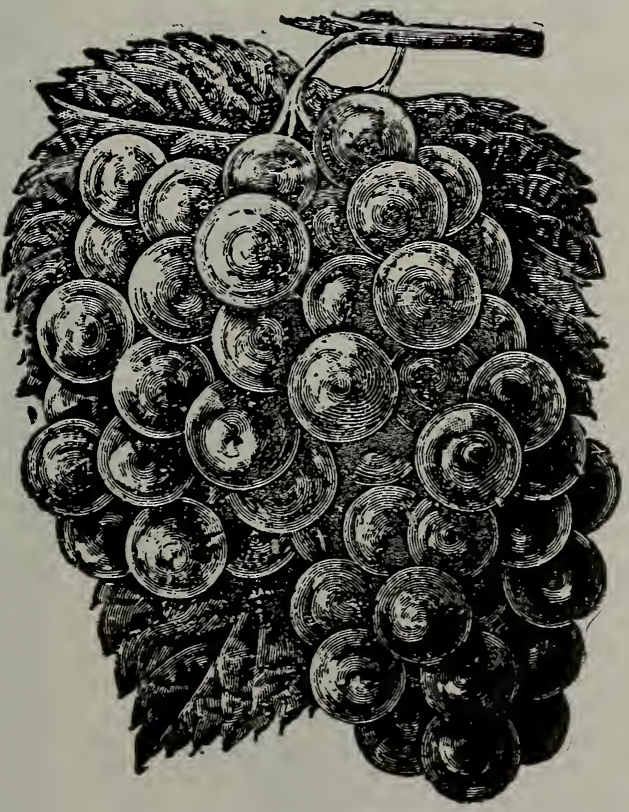

WORDEN (BLACE) 


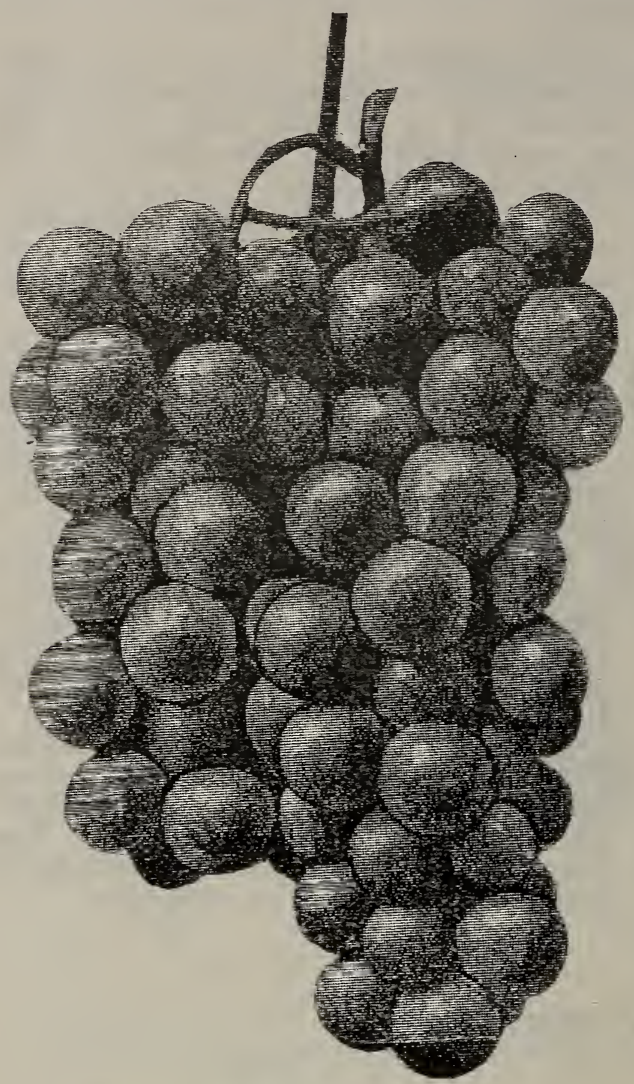

MOORE'S EARLY-A large grape, ripening a week earlier than Concord; good grower; berries large, good quality, and makes a moderate yield; very valuable as an early grape.

VERGENNES-Berries la $\mathrm{r}$ g e, holding firmly to the stem; light amber, rich and delicious. Is an excellent late keeper.

WORDEN-Seedling of the Concord, which it greatly resembles in appearance and flavor, but the berries are larger. The fruit is said to be better flavored and to ripen several days earlier. These qualities will give it the foremost rank among native grapes.

Paper bags slipped over the clusters as soon as they have formed are a good protection from fungus, insects and birds.

To destroy the grape curculio pest, spray with London purple as soon as fruit is set.

The borer manifests itself by the unhealthy appearance of the vine. Search at the roots and destroy the grub.

CAMPBELLS EARLY

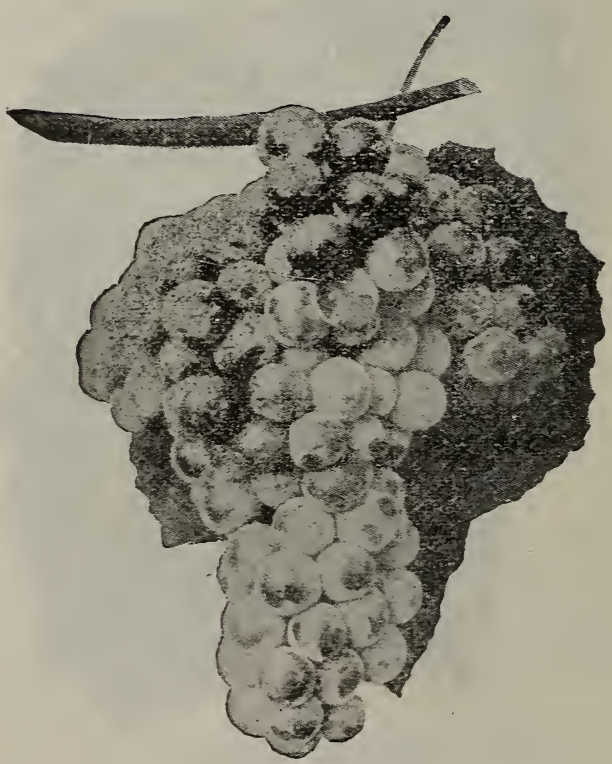

MOORE'S EARLY

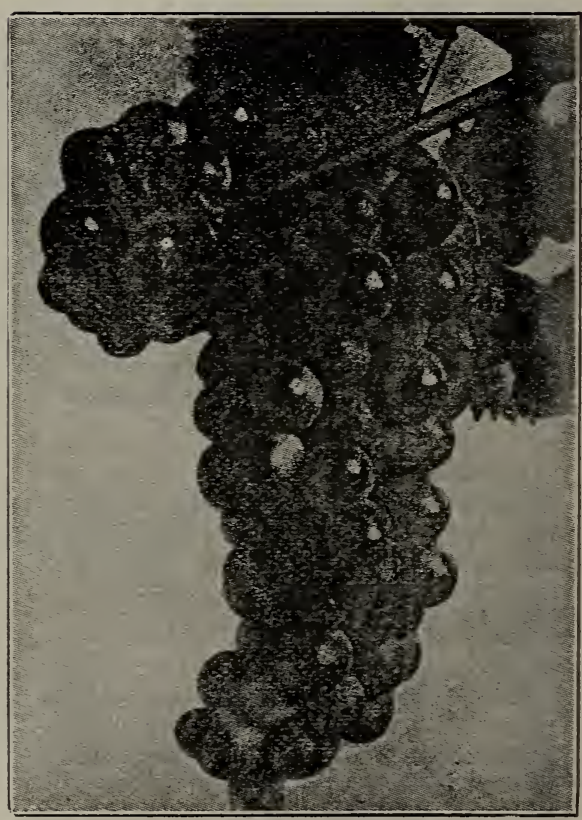

BEIGHTON 


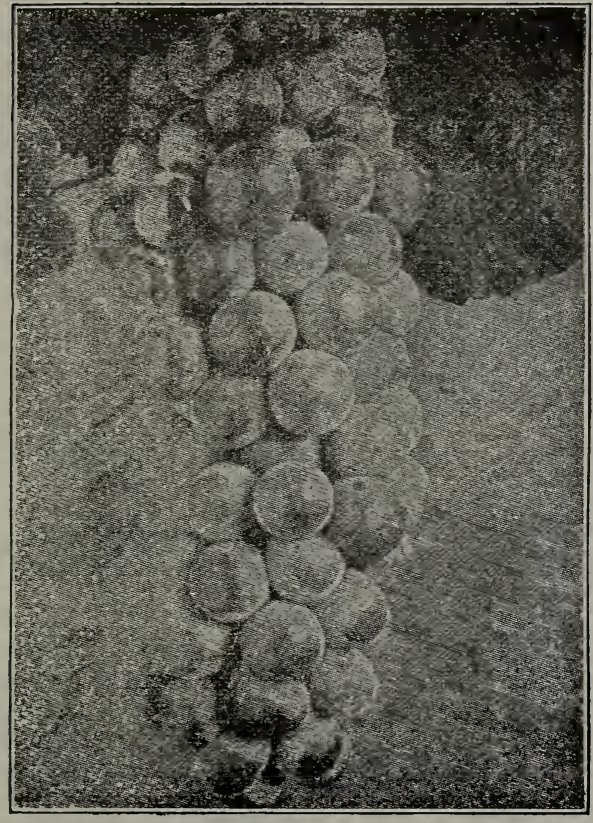

POCKLINGTON (WHITE)

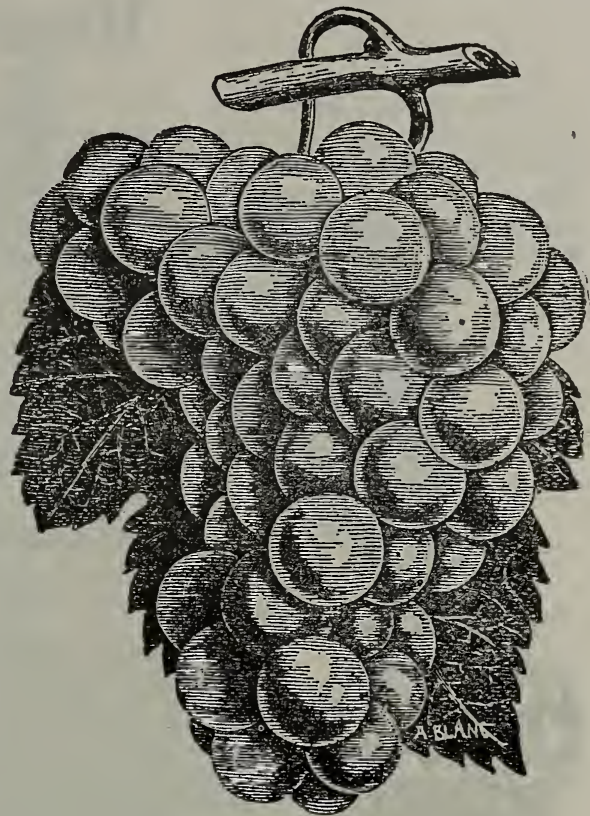

DIAMOND (WHITE)

WHITE GRAPES

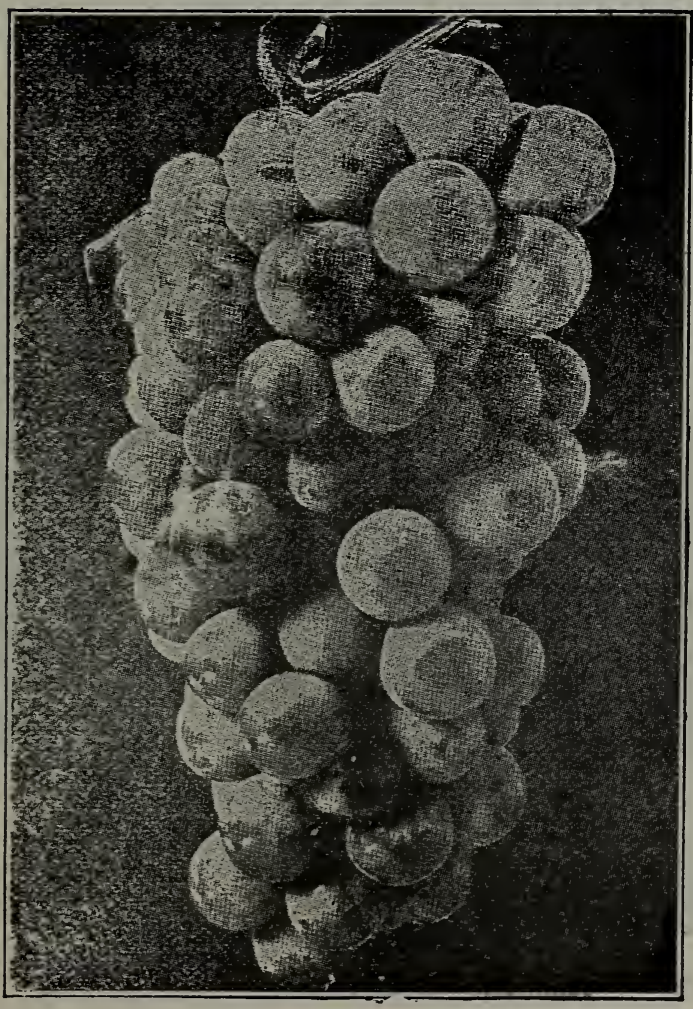

NLAGARA (WHITE)

MARTHA-Bunches and berries of medium size, greenish white, with a thin bloom; flesh tender, with very little pulp, juicy, sweet and rich, hardy and productive. $\mathrm{Ri}$ pens with Concord.

MOORE'S DIAMOND- $\mathrm{T} h \mathrm{e}$ leading, early white grape, ripening before Moore's Early. White, with a thin bloom; flesh juicy, few seeds, almost free from pulp, excellent quality; above medium size, adheres firmly to stem. Very like Concord in growth, hardiness and foliage.

NIAGARA-Occupies the same position among the white varieties as Concord among the black. Bunch and berries large, greenish white, changing to pale yellow when fully ripe. Skin thin but tough; quality much like the Concord.

POCKLINGTON-S e e d 1 i n $\mathrm{g}$ from the Concord. The vine is thoroughly hardy both in wood and foliage; it is a strong grower, never mildews in vine or foliage. The fruit is a light golden yellow, clear, juicy and sweet to the center, with little or no pulp; bunches very large, sometimes shouldered; berries round, very large and thickly set. Ripens with the Concord. 


\section{Raspberries}

The great improvement in the hardy varieties makes the cultivation of this fine fruit comparatively easy; any good soil will do, but a light, loamy one is preferable. Plant in rows five or six feet apart, leaving four feet between the plants; remove the old canes as soon as the fruit is gone, and do not allow more than three or four new ones to each hill; pinch the young canes when three or four feet high, and continue pinching in the laterals when a few inches long. Treated in this way they will need no stakes, but will be stout enough to support themselves.

\section{RED RASPBERRIES}

CARDINAL-New; originated in Kansas; heavy grower, hardy; berries firm and of excellent quality; very productive.

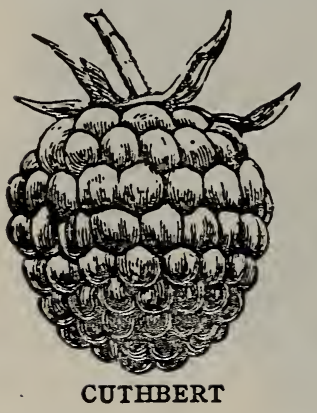

CUTHBERT-Cane tall and vigorous, berries large, conical, rich crimson and very handsome; best quality and carries well; very productive.

COLUMBIAN-The Columbian is a new variety of the Shaffer type, of remarkable vigor and productiveness. Not very hardy and propagates from tips. Fruit very large, of ten an inch in diameter, shape somewhat conical, color dark red bordering on purple; adheres firmly to the stem and will dry on the bush if not picked; seeds small and deeply imbedded in a rich juicy pulp with a distinct flavor of its own. Succeeds wherever red sorts do well and rromises to become the leading variety. A most delicious table berry.

HAYMAKER-Purple cap, not so dark as Shafier or Columbian. A splendid shipper and canning berry; does not crumble; excellent quality; vcry productive; plants vigorous and hardy.

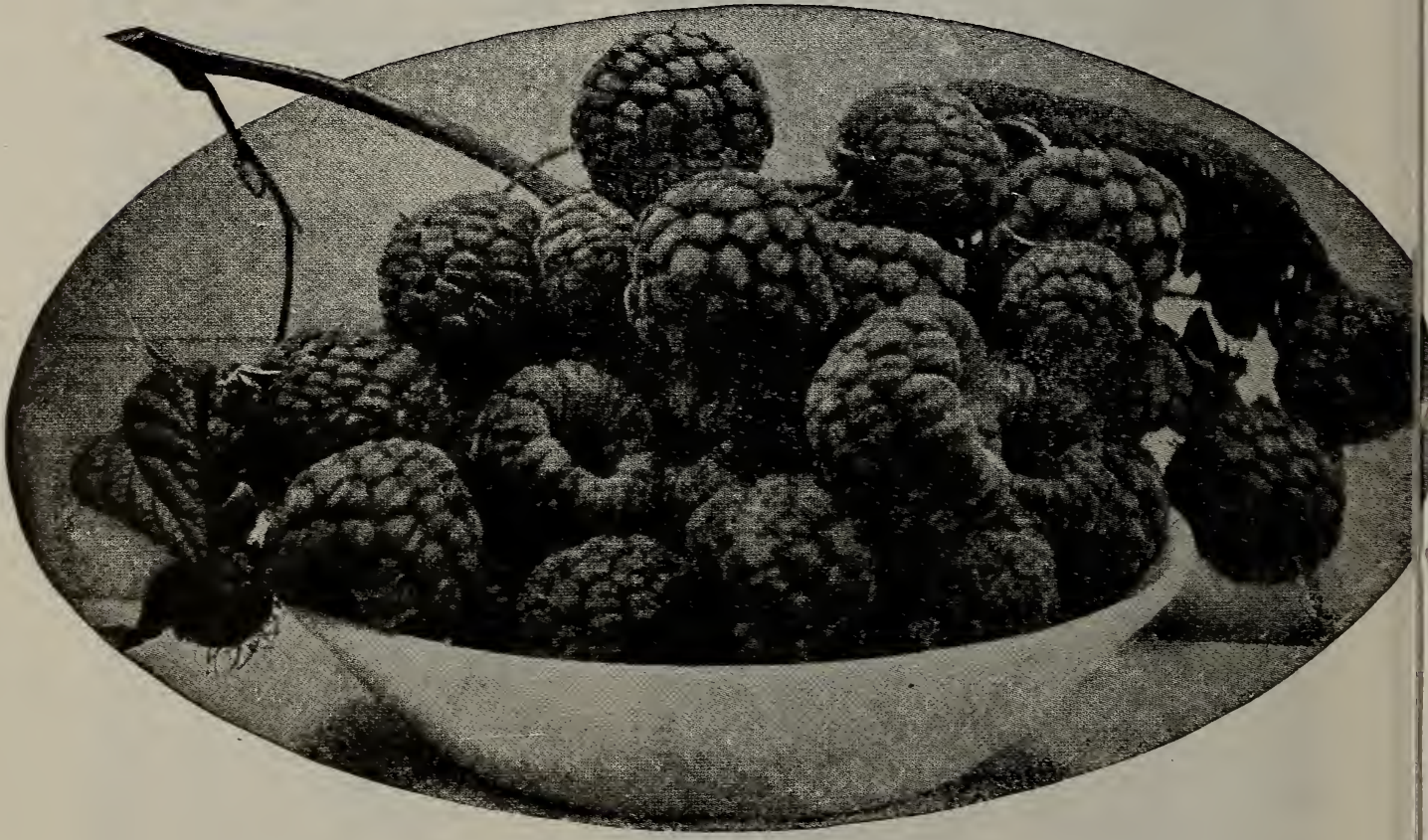




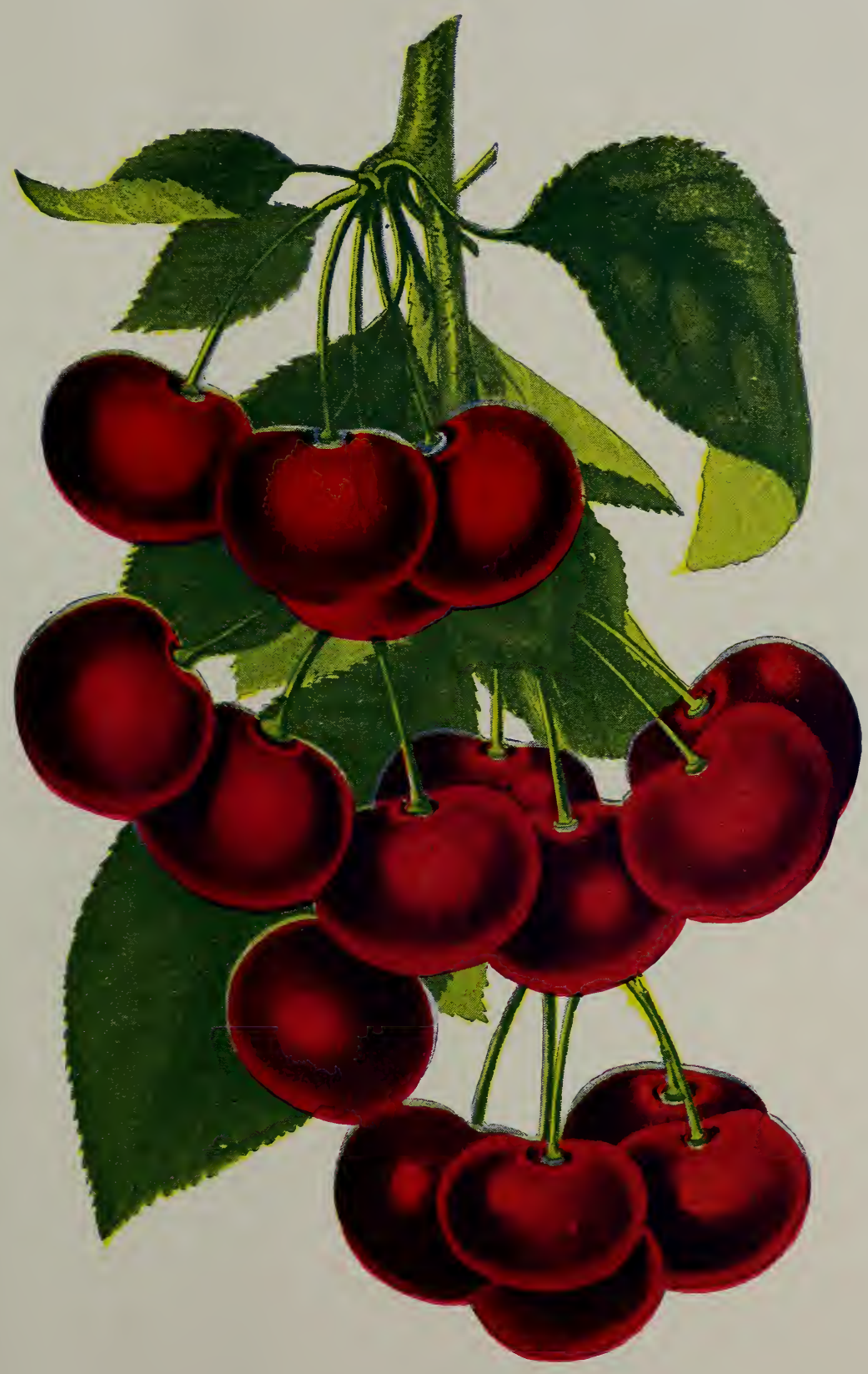

EARLY RICHMOND

Most popular acid Cherry, unsurpassed for cookirg; very early and abundarit; last of May and June. 


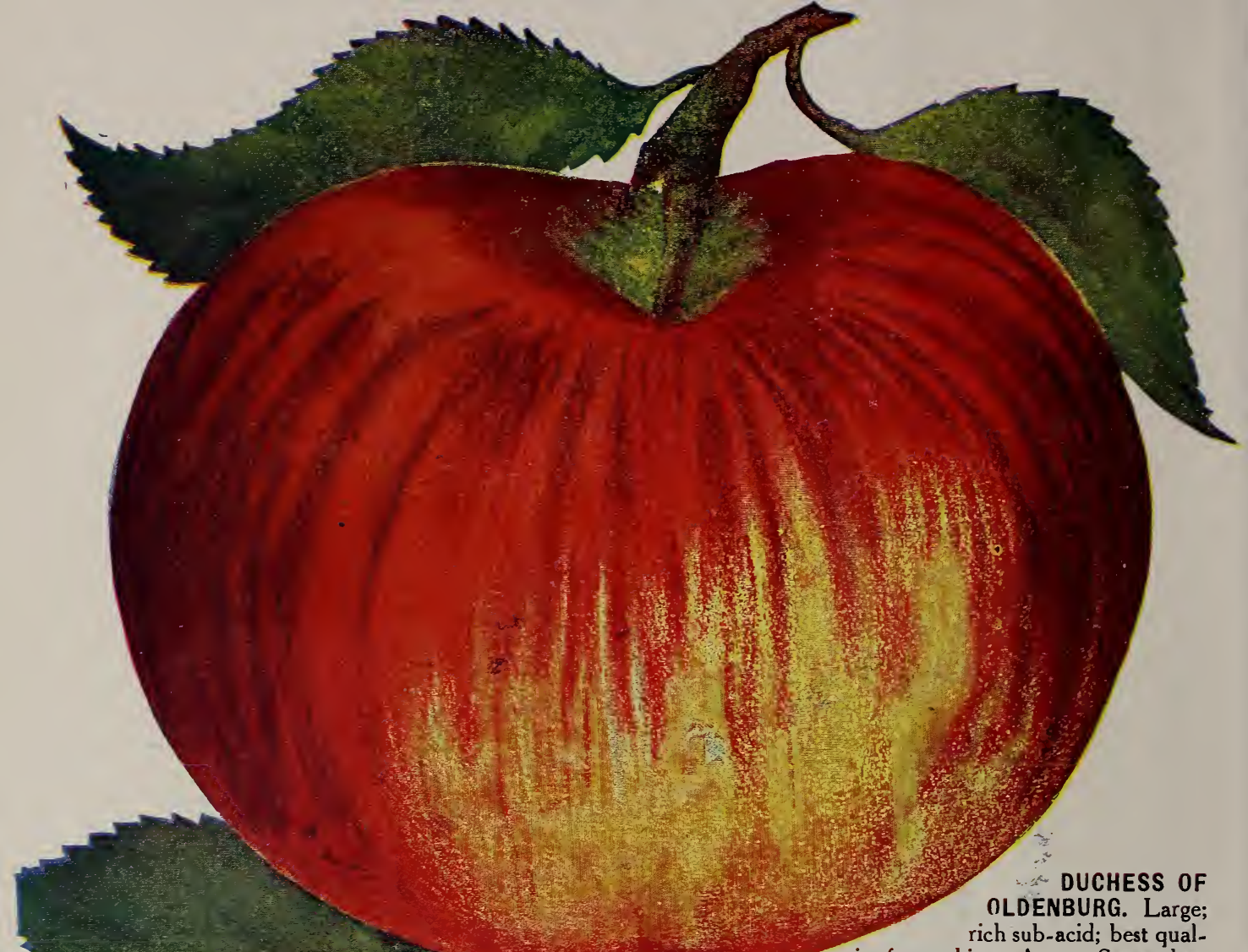
OLDENBURG. Large;
rich sub-acid; best qual-

YELLOW TRANSPARENT. Russian; very early; decidedly good; free growing; waxen yellow; July-August. ity for cooking. August-September.

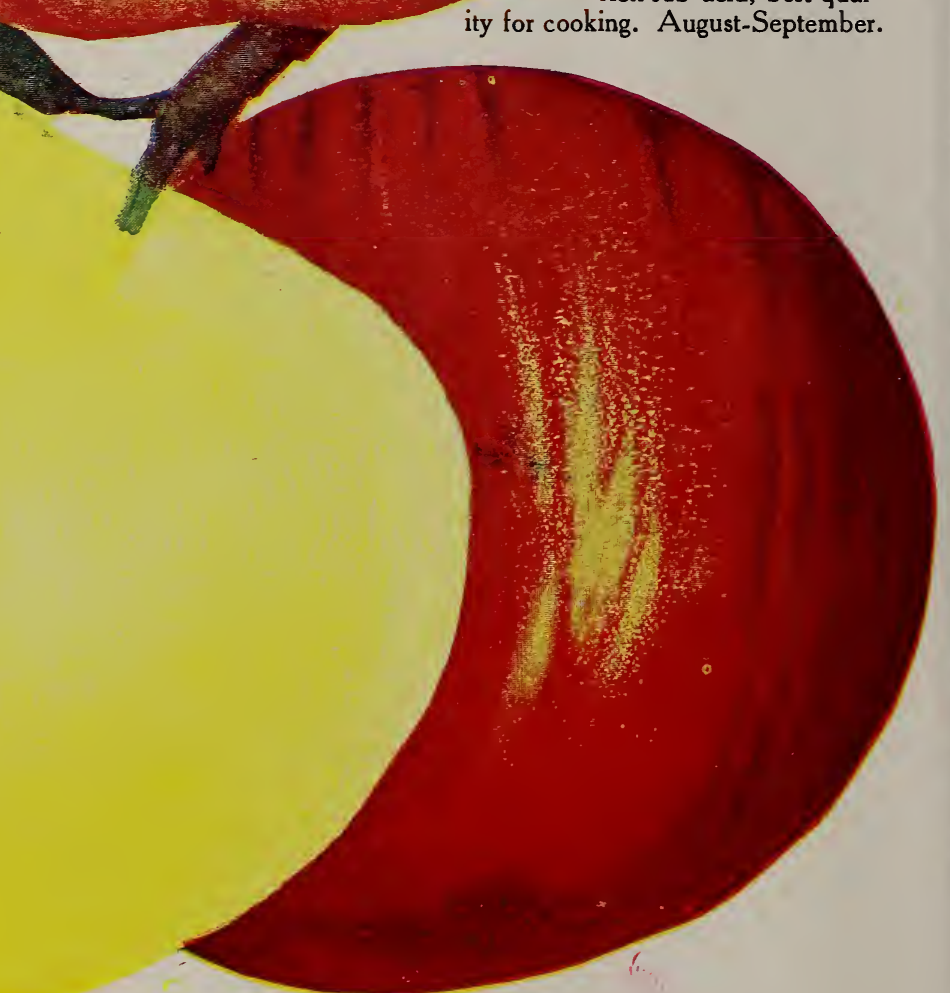

WEALTHY. Healthy; hardy; very productive; juicy; extra good; October to January. 


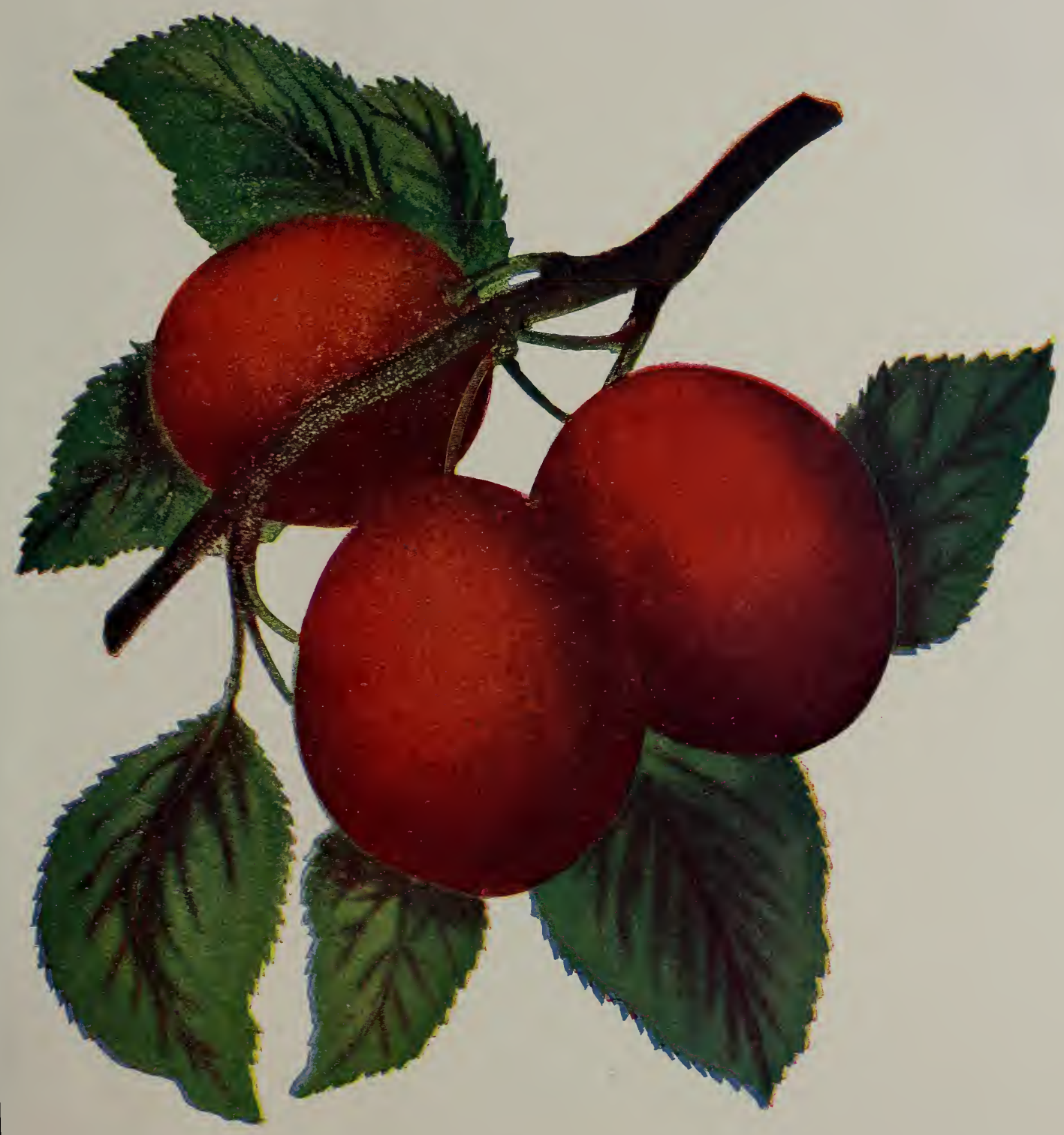

WILD GOOSE

An early and abundant native Plum; rapid grower; sweet; good quality; hardy. 


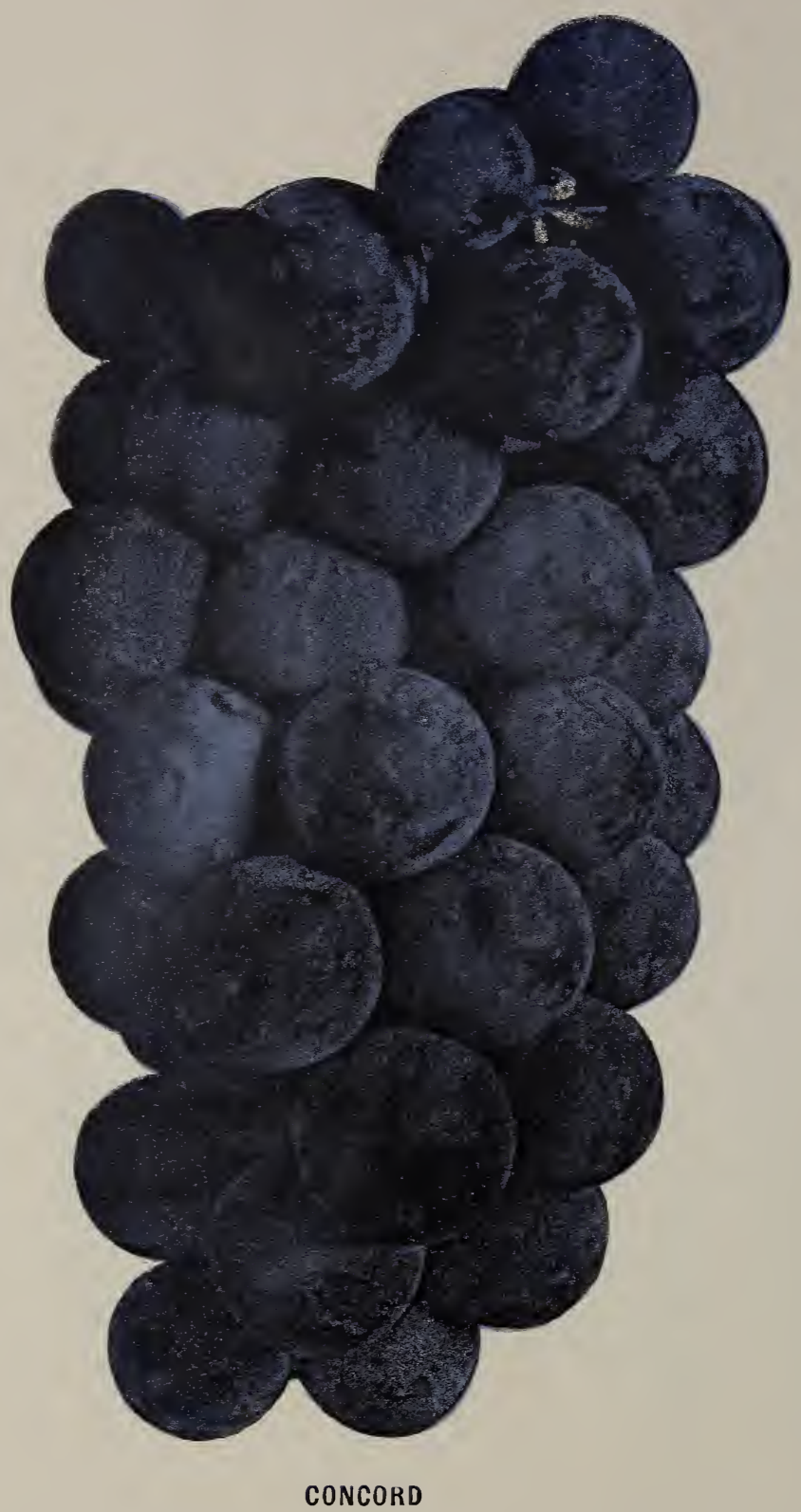

Universally healthy, hardy, productive; succeeds over widest range of soil; bunch large, compact; flesh juicy, buttery, very sweet; early. 


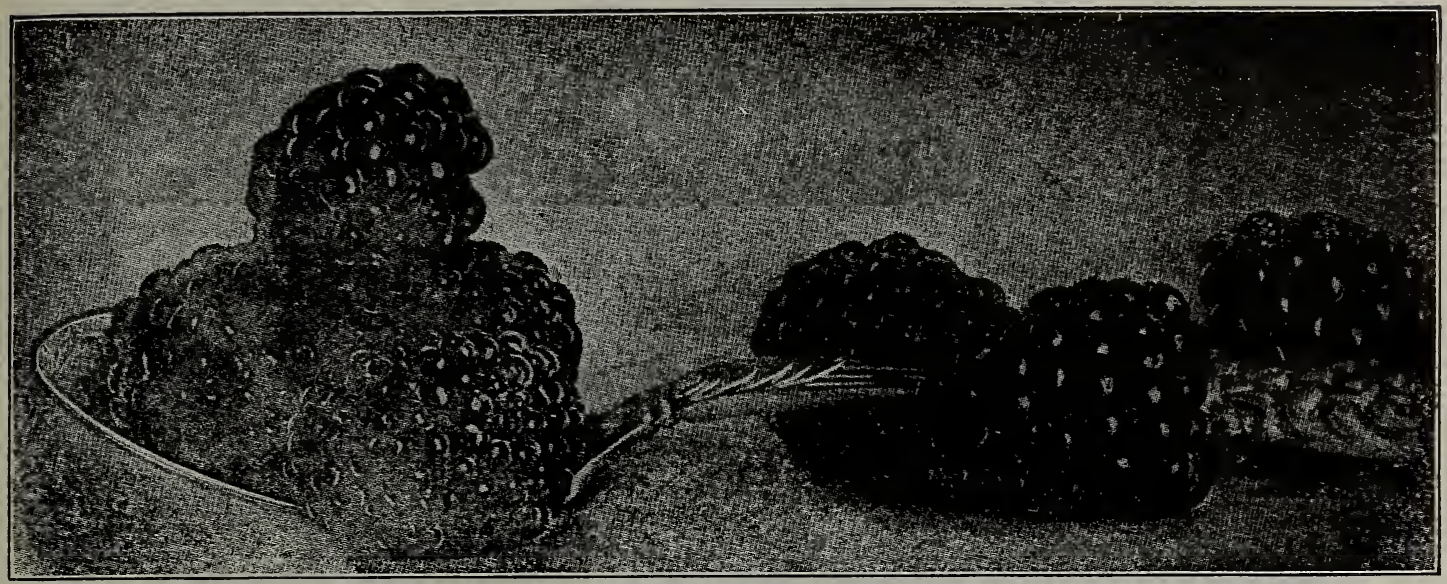

\section{CUMBERLAND RASPBERRIES}

LOUDON-The supcrior points of this excellent red raspberry are vigor of growth, large fruit, beautiful rich, dark crimson color; good quality and marvelous productiveness and hardiness. It stands shipping better than any variety and will remain on the bushes longest without injury.

MARLBORO - A profitable early market berry, with large, light crimson fruits of good quality and firmness. Very hardy and well suited to the North.

SHAFFER COLLOSAL-Fruit large, purple, rather soft, with sprightly sub-acid flavor. A very strong grower. Medium to late.

ST. REGIS-Plants of St. Regis planted in early April gave ripe berries on the twentieth of June of the same year. For four weeks thereafter the yield was heavy and the canes continued to produce ripe fruit freely without intermission until the middle of October. The berries were large and beautiful, firm and full flavored, to the very last. St. Regis is the only Raspberry, thus far known, that will yield a crop of fruit the season planted. Price 40 cents each, $\$ 3.00$ per 10 .

\section{YELLOW RASPBERRIES}

GOLDEN QUEEN-Large, beautiful translucent amber color and exceptionally firm; very productive. The canes are of the strongest growth and quite hardy.

\section{LOGANBERRY}

Hybrid between a blackberry and red raspberry, produced in California. Fruit as large as a blackberry, but of deep red color. Of questionable hardiness and utility. Excellent as a novelty.

\section{BLAC $\bar{K}$ RASPBERRIES}

Pinch back blackcaps early, or when the young canes are about 3 feet high, to keep the bushes snug and compact, and to avoid staking. Clean mellow culture is beneficial to both varieties of Raspberries, and mulching, both in summer and winter, is of decided benefit to them.

This class of Raspberries, rooting at tips, should be planted very shallow. The bud in the cluster of rootlets should be placed upward, and only 1 or 2 inches below the surface. Pay no attention to the picces of old cane left to handle them by. Thousands of plants are smothered by too decp planting.

CUMBERLAND ("The Business Black-Cap.")-Largest raspberry known, fruit frequently seven-eighths to fifteen-sixteenths of an inch in diameter. Its immense size, firmness, and great productiveness entitles it to above designation; unusually strong grower, throwing up stout stock canes; perfectly hardy. Is by far the most profitable raspberry grown for both home and market use.

GREGG-This is the extra big, late blue-black fellow. Heavy growing canes that branch out sparingly; hardy; productive of very large, firm black berries, covered with a deep bloom. Late ripening and good quality makes it a general favorite.

KANSAS-Originated at Lawrence, Kan. Healthy, vigorous grower; early; berry as large as Gregg and as good a shipper. Very productive, and valuable for early market. 


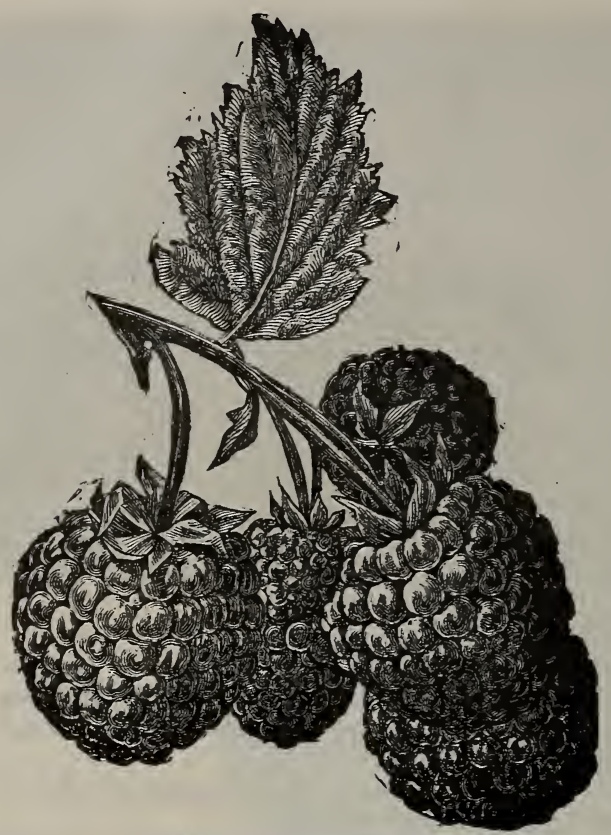

KANSAS RASPBERRIES
LOTTA-A fine new berry originated at Lawrence, Kan. Has steadily grown in favor. As large, good and handsome as Gregg, and one week earlier, being midway between Older and Gregg. It is one of the most profitable berries for market.

MAMMOTH CLUSTER-A large and very productive variety of black cap. Quality good; ripens before the Gregg.

NEMAHA - Originated in Nemaha county, Nebr. Seedling of Gregg; very similar to it, but later and of better quality; stands more upright. A good sort for our dry prairie regions.

OLDER-Originated in Iowa ten years ago and has stood all our severest winters well. Coal black, as large as Gregg and five days earlier. From its size, quality, hardiness and great productiveness it promises to head the list when better known.

PALMER-A new early black cap variety; ripens its fruit just before the Gregg, but ripens it in shorter time. Good quality; vine is a strong grower and one of iron clad firmness.

\section{Blackberries}

Any moderately rich soil will answer for their cultivation, but to avoid a too strong growth and straggling habit the ends of the shoots must be occasionally pinched in during the growing season, thereby encouraging the plants to form dwarf bushes, making it easier to work among them, and at the same time causing the plants to produce a larger crop and finer berries. An annual dressing with manure will produce an excellent effect on the succeeding crop of $f$ ruit

\section{ANCIENT BRITON-On}

of the best hardy varieties. very vigorous, healthy, hardy' loaded with good-sized berries of fine quality, carry well to and fetch highest price inmarket. For general planting in sections subject to severe winters, the Ancient Briton is a first-class variety.

ERIE (Uncle Tom)-It is the most vigorous and healthy plant of any blackberry we have ever grown and thus far absolutely hardy. Very productive of berries of the largest size, coal black, firm and solid. Fine form and ripens early.

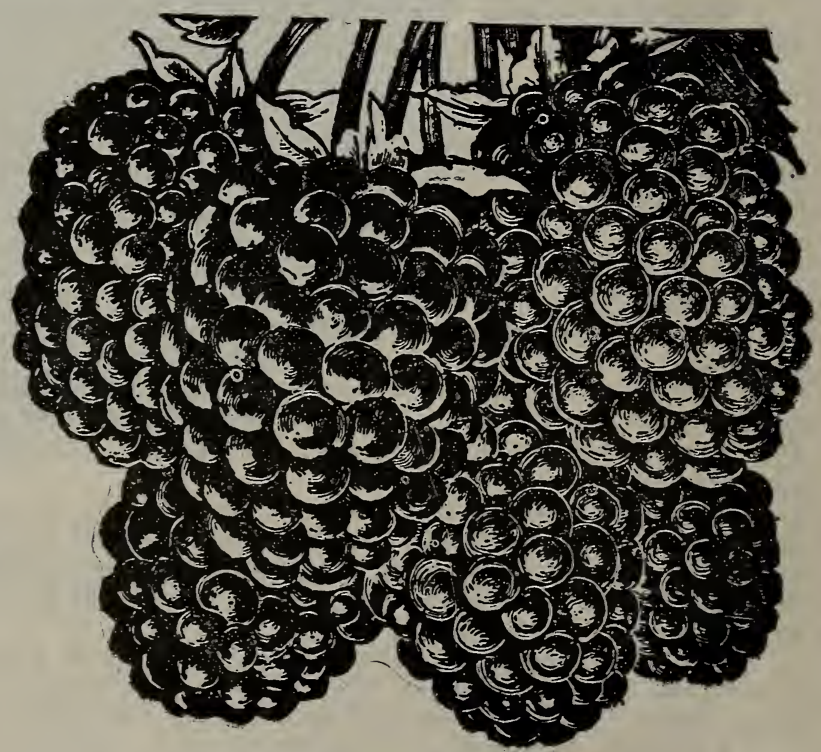

SNYDER BLACKEERRIES 


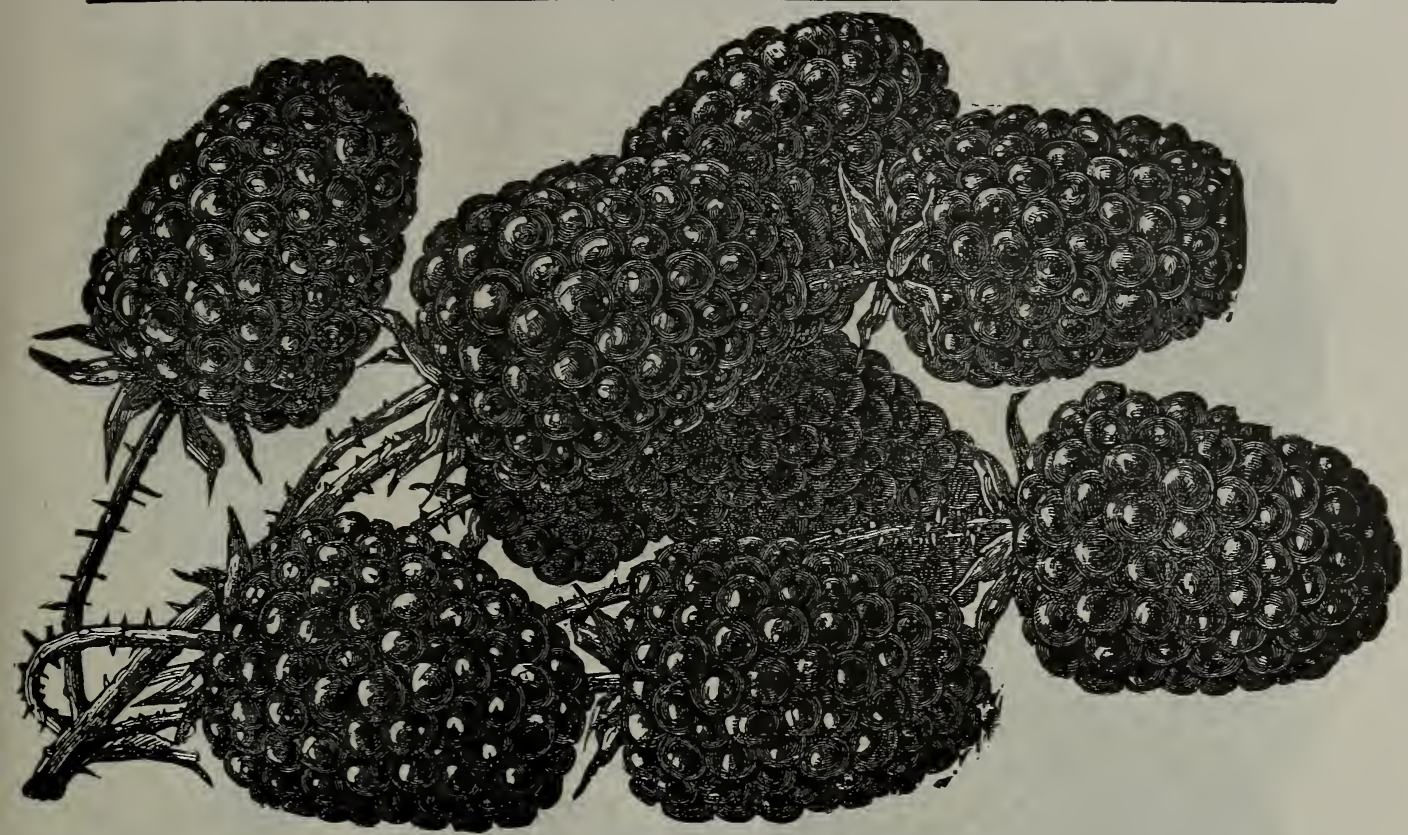

\section{MERSEREAU BLACKBERRIES}

MERSEREAU-Originated in northwestern New York. Renowned for hardiness of cane, great productiveness and large size berry. Is not "seedy" like many other sorts. Fruit jet black, and does not change color. Berries rich, melting and luscious, with little or no core. It has a record of yielding 12,000 per acre.

MINNEWASKI-Berries large, juicy, sweet. Remarkably productive and hardy. Ripens early.

RATHBUN-This new blackberry has been tested over a wide area and is said to surpass any blackberry on the market. Berries large, jet black and of very fine quality. Ripens early.

SNYDER-The old standard. Very hardy, consequently much raised in cold climates. Berries medium size, juicy, rich; strong, stout cane; thrifty growth and a very broad leaf.

STONE'S HARDY-Is claimed to be even hardier than Snyder. It is a vigorous grower; berries glossy black and of a good flavor. About eight days later than Snyder and lasts two weeks.

TAILOR-A good succession for Snyder in cold climates. Ripens its large, luscious berries some weeks later. Vigorous, hardy, fruitful.

WILSON-A very superior, large, early berry, of sweet and excellent quality. Strong-growing, amazingly fruitful, very early to ripen.

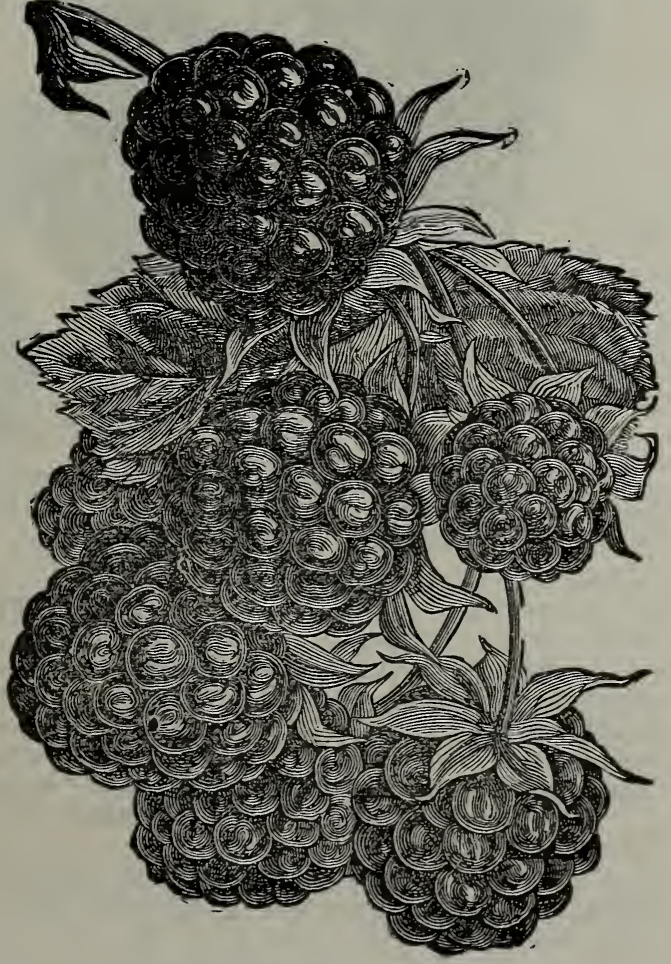

RATHBBUN BLACKBERRIES 


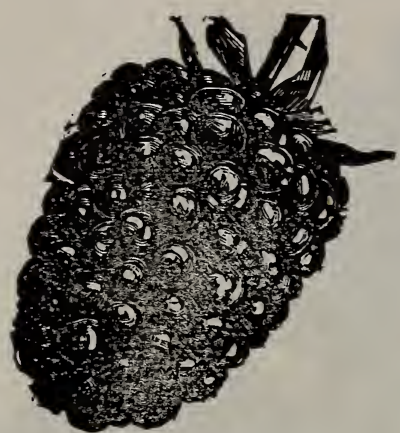

ANCIENT BRITON

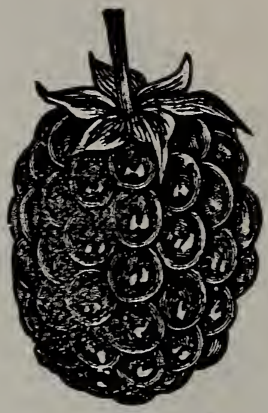

EARLY HARVEST

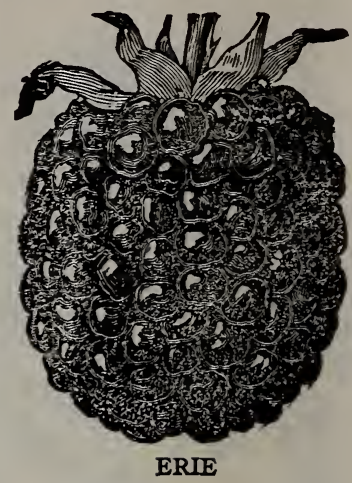

EARLY HAñ-VEST-This is one of the earliest blackberries, but needs winter protection. Fruit meaium size, quality good and prolific bearer.

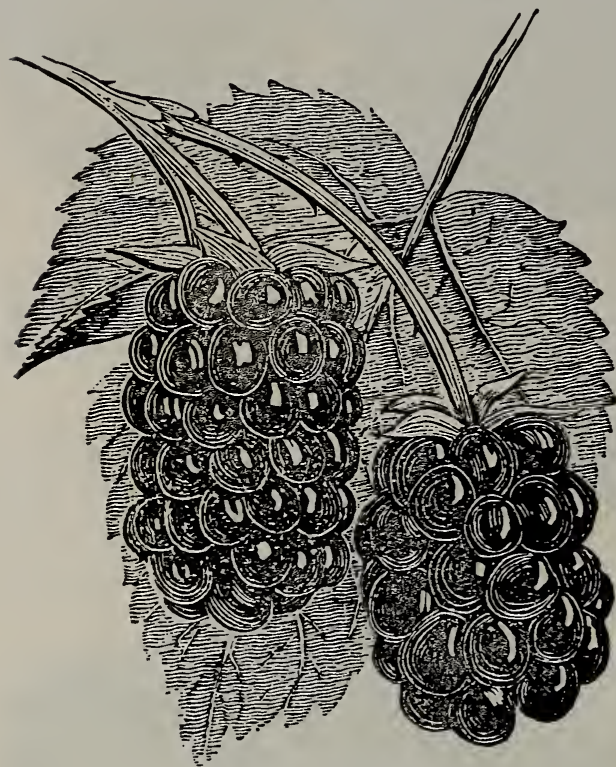

IUCRETIA DEWBERRY

\section{Dewberry}

LUCRETIA-Fruit very large, luscious and handsome; periectly hardy, a strong grower and enormously productive; a superb and very profitable market fruit; the vines should be allowed to remain on the ground during the winter and staked up early in the spring.

\section{STRAWBERRY-RASPBERRY}

One of the recent introductions from Japan. Seemingly a hybrid between strawberry and raspberry. Bush dies to the ground in the fall. Fruit red, in size and shape like a strawberry. In northern states it should not be planted for the fruit, but as a novelty, if at all.

DWARF JUNEBERRY

Fruit borne in clusters. Reddish purple, changing to bluish black. Excellent for canning. The fruit is eagerly devoured by birds, which leave the finest fruits untouched where this is plentiful.

\section{Currants}

Currants should be planted four feet apart in the garden. The currant flourishes in almost any kind of soil, but to have the fruit in perfestion plant in $\mathrm{r}^{-i} \mathrm{sh}$, deep soil, and give good annual pruning and cultivation. When plants are grown as bushes the older and feebler suckers should be cut out. When grown in a form of a tree with a single stem, the bearing wood should be thinned and the stem and roots kept free of suckers.

BLACK NAPLES-Very large, black, rich, tender and excellent for jellies and wine. Very productive.

CHERRY - The largest of all red currants; berries sometimes more than one half inch in diameter; bunches short; plant very vigorous and productive when grown on good soil and well cultivated. 


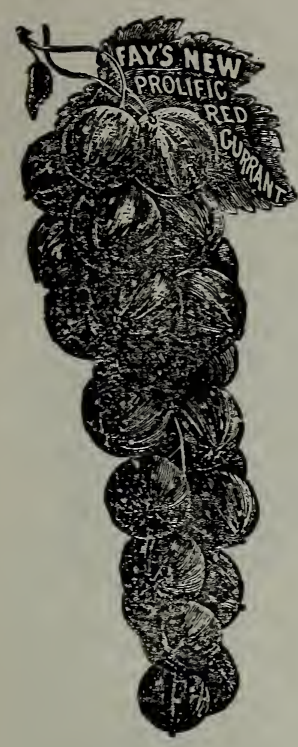

FAY'S PRCLIFIC-For size, beauty and productiveness the most remarkable red currant ever grown. The berry is fully equal to cherry currant, while the flavor is much superior. The stem is double the length on an average, and the fruit hangs on well, never dropping, as in other currants.

HOLLAND-A very strong grower; canes stout and capable of holding up the enormous crop it always bears. It is quite late, thus prolonging the season.

LA VERSAILLAISE-Resembles the Cherry; large; of great beauty and productiveness.

NORTH STAR - New seedling; very vigorous; perfectly hardy; bunches long and well filled with fruit.

PERFECTION-In color it is a beautiful bright red, and of a size larger than the Fay; the clusters average longer and the size of the berries is maintained to the end of the bunch. It is one of the most productive Currants we have ever known, and in quality it is superior to anything in the market, being of a rich, mild, sub-rrid flavor and having plenty of pulp with few seeds.

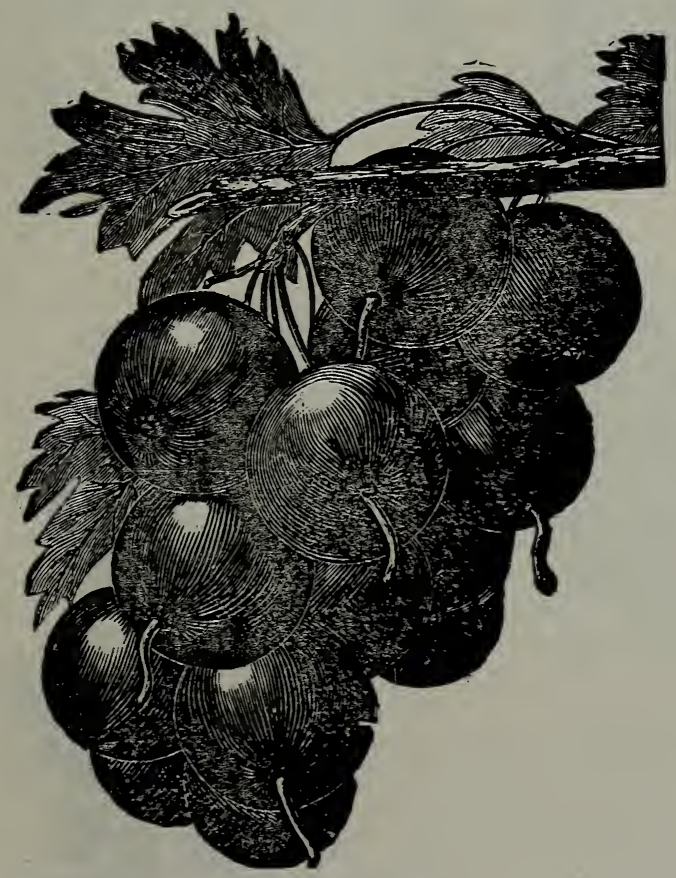

PERFECTION CURRANTS

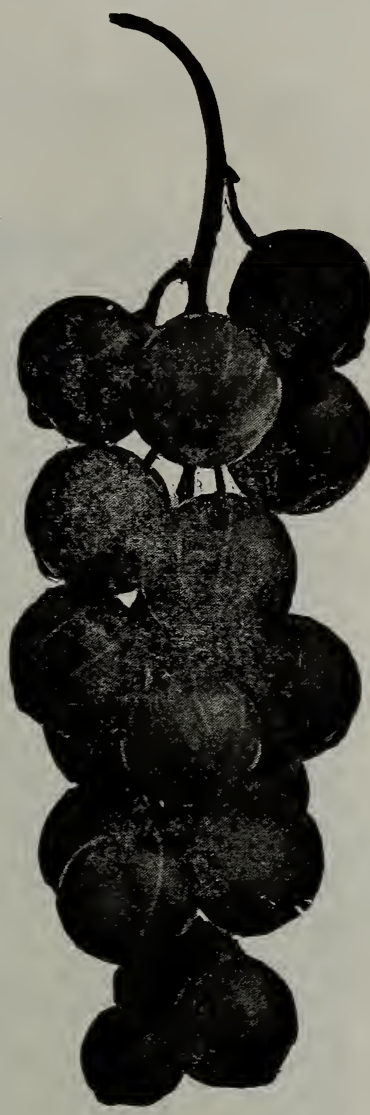

VICTORIA CURRAIT̃ S̄

POMONA-This is one of the rnost profitable currants for the market; while not the largest in size, it outyields all other varieties. Color is a beautiful bright red, berry sweet and less acid than most of the general varieties; good size, and larger than Victoria; a vigorous growe- with healthy, hardy foliage.

RED DUTCH-Old, well-known sort of good quality; great bearer. Fine market variety. Vigorous and upright grower.

WHITE DUTCH-White; medium size; vigorous grower and good bearer; bunches very compact; early. Fruit requires less sugar than some others; excellent for jellies.

VICTORIA - Very large; bright red; bunches very long; late; very productive and valuable. This is a standard, good, and reliable currant.

WHITE GRAPE-Very large, yelowish white; sweet, or very mild acid; excellent for the table. The finest of the white sorts, very productive. 


\section{Gooseberries}

The gooseberry delights in a deep, exceedingly rich soil, as recommended for currants, and thorough mulching. Cooseberrics have never received the attention they deserve. The markets are scarcely ever fully supplied. Each year the

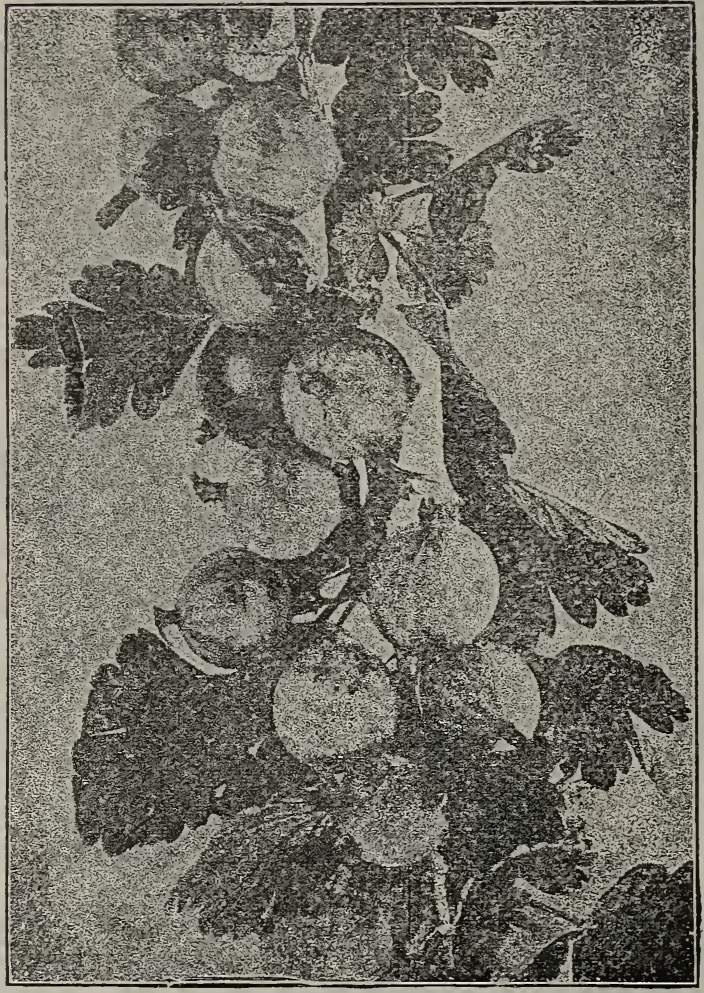

FOUGHTCN GOOSEEERRIEN

PEARL-A cross between Houghton and one of the arge English varicties. It is ver $y$ hardy and entirely free from mildew; superior in size and quality; more productive than Downing, and is likely to supersede this standard sort.

SMITH'S IMPROVED-Much like Downing; strong grower; large berry; productive only under high cultivation.

In order to produce large, abundant crops it is necessary to manure heavily and prune closely. Mildew is prevented by close planting and heavy mulching. Plant three to four feet each way. demand is greater and no one will make a mistake in planting quite liberally of this most healthful, invigorating fruit.

D O W IN I G-Fruit very large, flesh whitish green, soft, juicy and good; plant vigorous and prolific; one of the best.

HOUGHTON-The old, wellknown sort; pale red, sweet and good. It is rather small, but a pioductive, healthy and very reliable gooseberry.

I N D U S T R Y-Very large; dark red, hairy, of delicious quality. In a cool, rich soil with a northern exposure it will yeild an abundance of large, luscious fruit. Under favorable conditions its immense crops and exemption from mildew will repay the attention it requires. Not an ironclad. English sort.

JOSSELYN - An American seedling of large size, smooth, prolific and hardy, of best quality. Has been well tested over a wide extent of territory by the side of all the leading varieties, and so far the freest from mildew both in leaf and fruit, of them all. A wonderful cropper, with bright, clean, healthy foliage. The one large Gooseberry that can be planted with entire confidence.

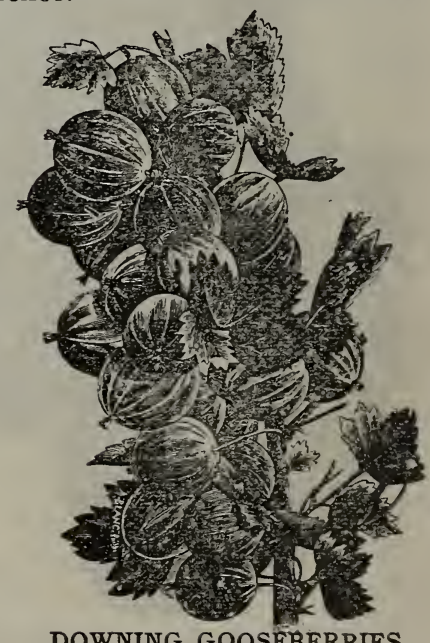




\section{Strawberries}

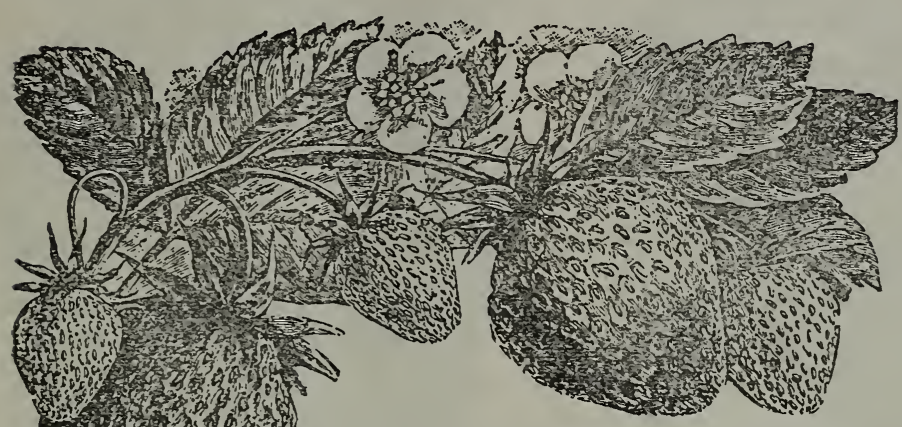

Strawberries will succeed in any soil that is adapted to any ordinary farm or garden crops. Soil should be thoroly prepared to a good depth, well drained and enriched. For field culture set in rows three or three and one-half feet apart, fifteen to eighteen inches in rows; for garden fifteen to eighteen inches each way, leaving pathway every third row. Ground should always be kept clesil and well cultivated. In winter a covering of leaves, straw or some kind of litter will protect the plants. Do not cover thcm until ground is frozen or so deep as to smother the plants, and remove covering before growth starts in the spring. When the berries are set discontinue cultivation and mulch

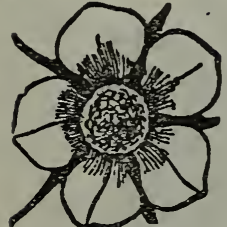

IMPERFECT lightly which will keep the fruit clean and the soil in good condition during the fruiting season. The blossoms of all varieties marked "S" are bi-sexual or perfect, those marked " $\mathrm{P}$ " are destitute of stamens and are termed pistillate or imperfect, as are shown in the accompanying figures. Imperfect varieties should have a row of perfect flowered sorts planted every third or fourth row to pollenize

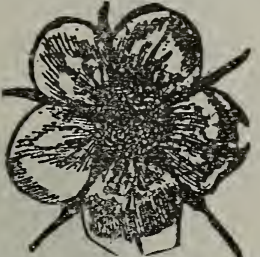

PERFECT

their blossoms. When imperfect blossoms are properly fertilized they are the most prolific.

BEDERWOOD. (S)-This is one of the best standard varieties for market. It is early, a very strong yielder and continues a long time in bearing. A very strong staminate the very best fertilizer for Warfield, Crescent or Haverland
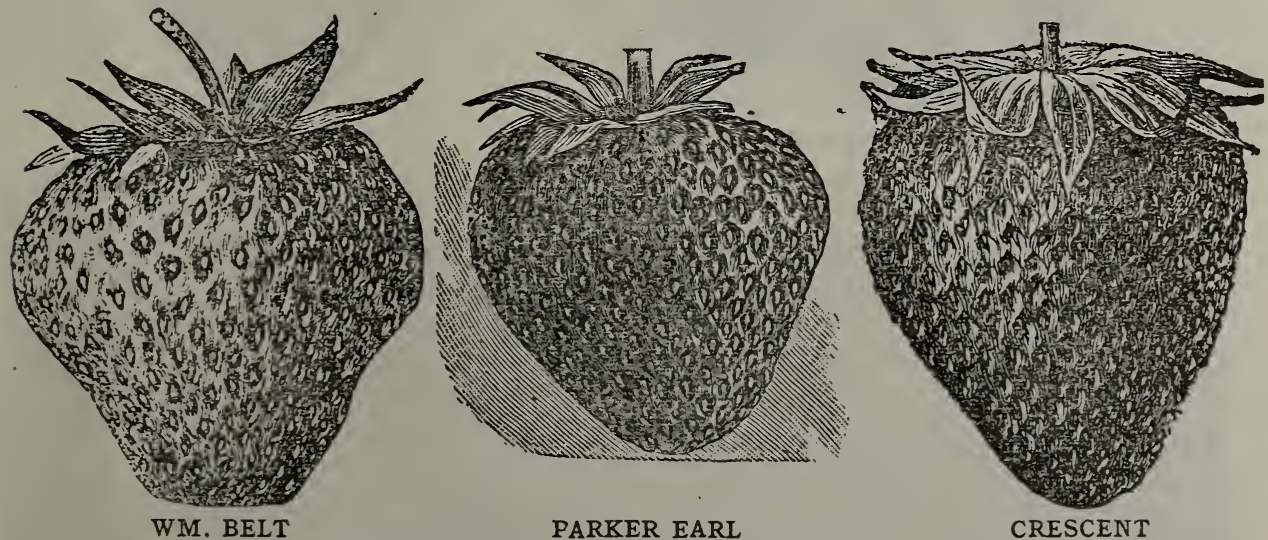

BRANDYWINE (S)-A fine, large, late, handsome, productive berry of excellent quality, regular conical form; dark glossy red, extending to the center. Flant healthy and vigorous, abundant producer. An extra good sort for all purposes. 


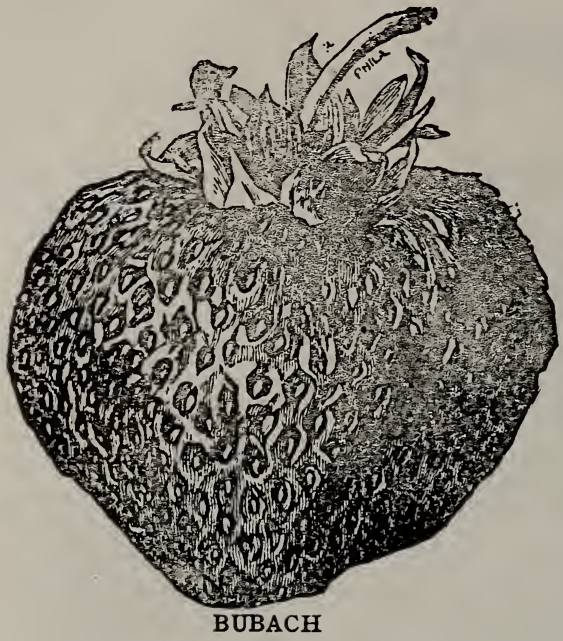

BÜBACH NO. 5.-(P) Very prolific, of excellent flavor and in size "simply immense." Berries all average large. A number of new varieties have been pitted against it, claiming superiority in one way or another, but we predict the Bubach will come out first best, and continue to grow in favor.

CLYDE (S)-A healthy, vigorous grower and very productive. Fruit large, bright red, good quality. As far as tested is giving the best of satisfaction.

CRESCENT (P) -This is an old and reliable sort. It is especially adapted for sandy soil, as it is a great plant producer and on rich loam makes an overcrowded, matted row. Good.

HAVERLAND (P)-Profitable by reason of its productiveness and earliness; requires deep, heavy soil; plant exceedingly vigorous and healthy; fruit large, handsome and good, rather long in shape and of a bright, glossy crimson; early.

JESSIE (S)-The plant is a stout luxuriant grower; foliage light green; large, and clean; it is a beautiful color, fine quality, good form, quite firm.

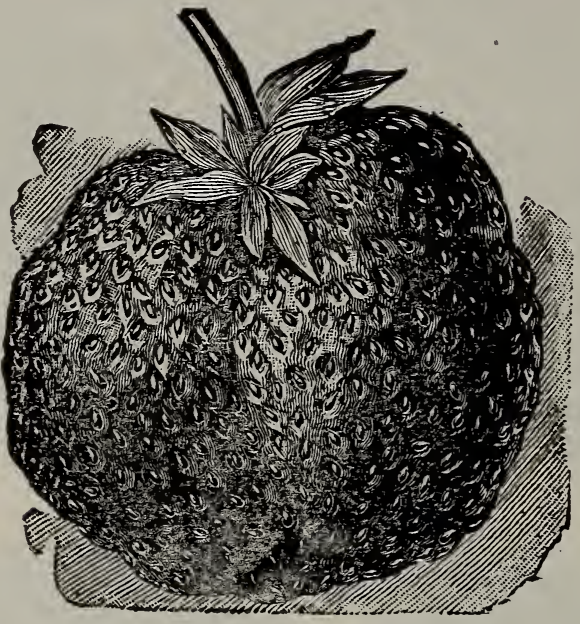

ROUGH RIDER

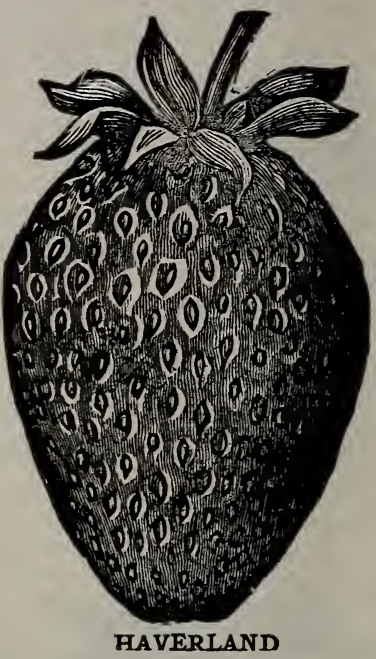

HAVERIAND

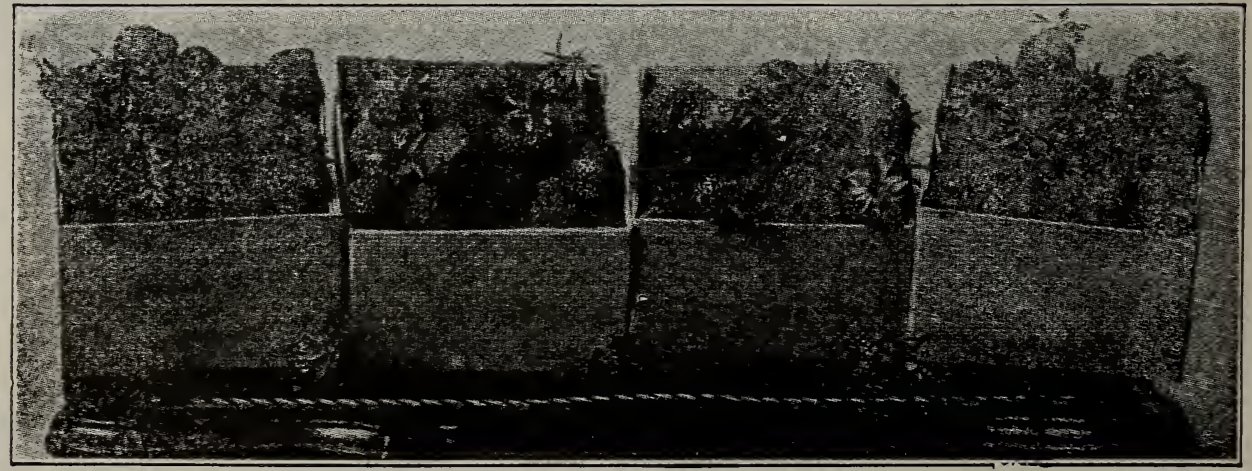




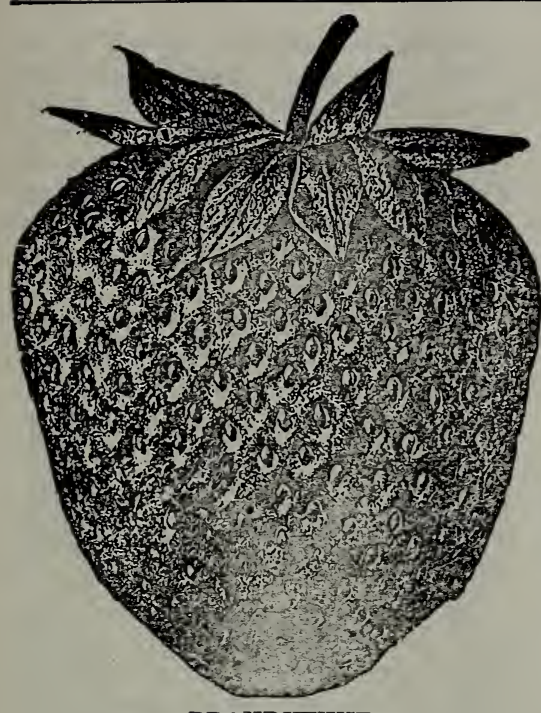

BRANDYWINE

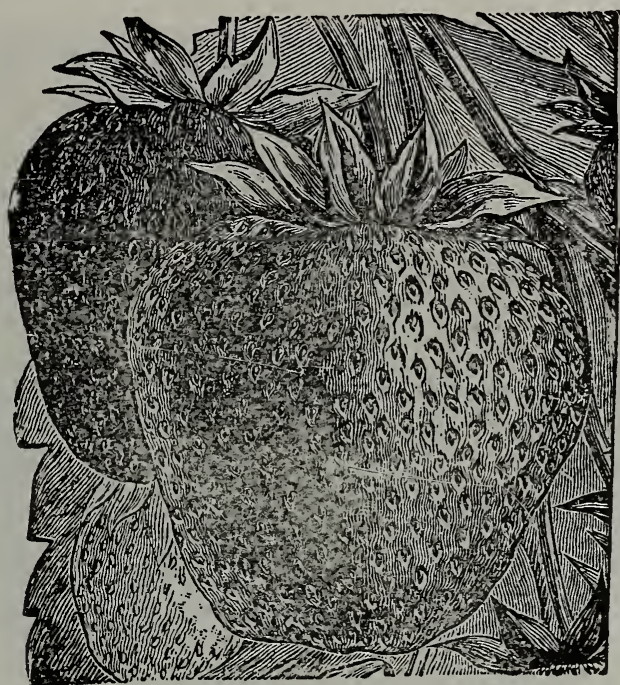

NEW HOME

LADY RUSK (P)-A vigorous grower; withstands heat and drouth to perfection. Earlier than Crescent. Flavor rich and excellent.

LOVETT (S)-This is one of the best market varieties. It succeeds generally in any soil or locality, it is of the tough, hardy varieties. The plants are rank and vigorous. The fruit is of good uniform size, of a high rich color, and splendid flavor.

MARSHALL (S) - An exceedingly handsome, high colored, very large berry of extra fine quality; ripening early. Plant very strong, with high culture produces heavy crops. The best early large variety.

MICHEL'S EARLY (S) -Plant a strong grower, in most sections productive; berries medium size, roundish, bright crimson, fair quality. One of the first berries to ripen and worthy of planting everywhere on that account.

NEW HOME (S) - Introduced in 1905 and has been thoroughly tested over a large scope of country; fruit of a bright red color that holds its lustre well after being picked. Produces well on either high or low ground. Easy to pick and ranks among the first in productiveness.

NICK OHMER (S)-Very large and stocky, sending out plenty of very strong runners, probably not surpassed in healthy, vigorous growth and productiveness by any variety. The fruit is of the largest size, never misshapen. Its only departure from the regular roundish conical form is when, under high culture, it is somewhat triangular. It is dark, glossy red, firm and of excellent flavor.
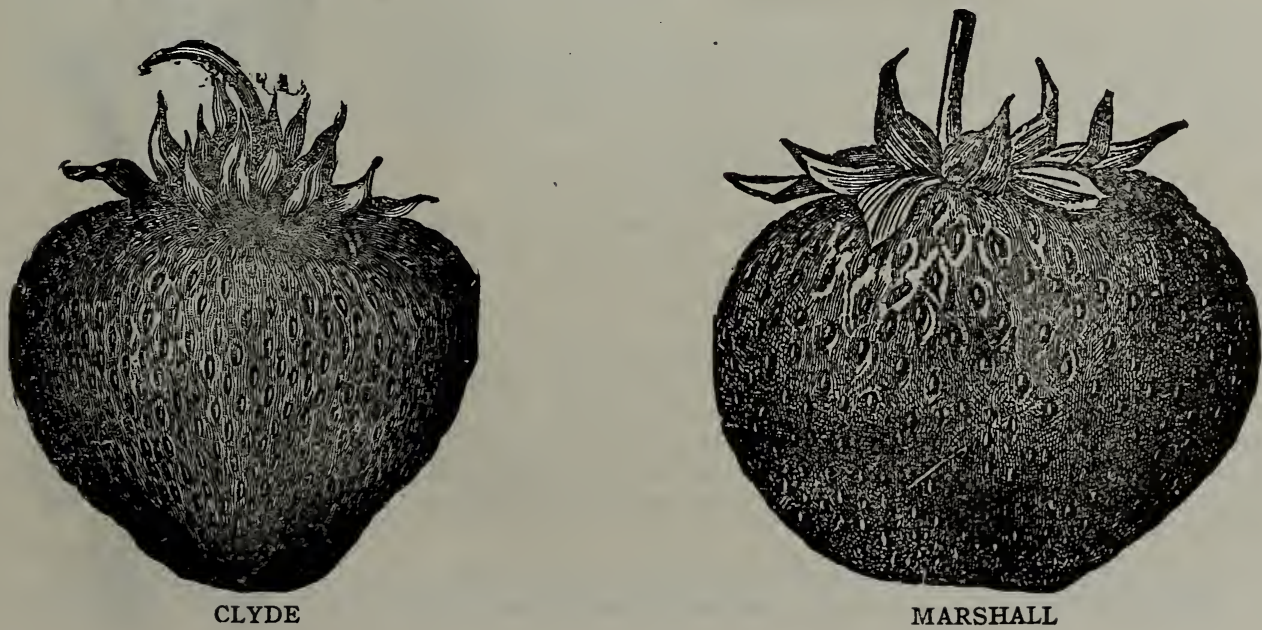


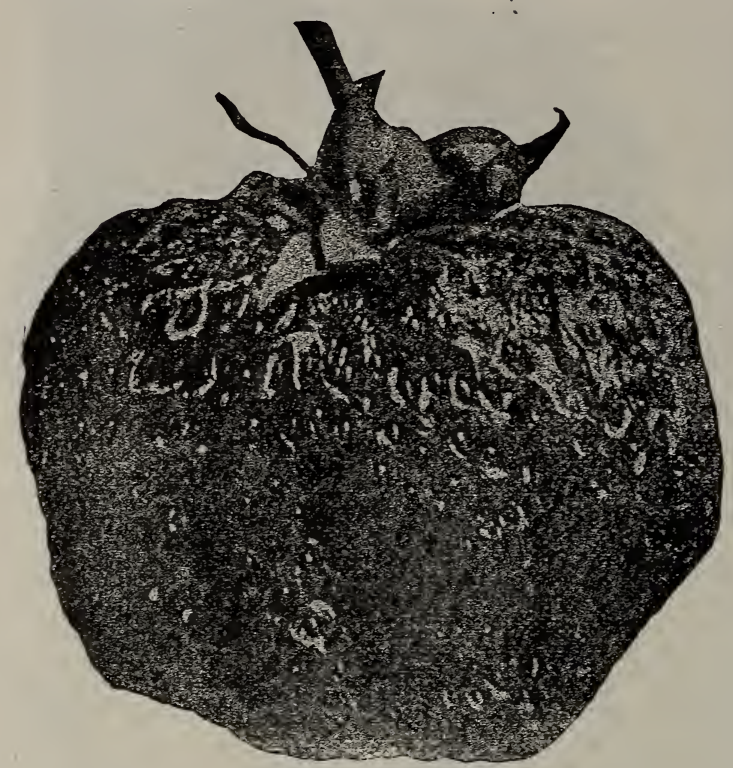

PARKER EARLE (S)-T $\mathrm{h}$ i s variety should be planted on rich soil. Should be grown in hills. Give it the best of cultivation and the crop will astonish you, but it will prove a failure, if planted on thin soil or matted rows. It sets so many berries it cannot mature them on poor soil.

ROUGH RIDER (S)-Perfect blossom, very productive, extremely vigorous, very large and attractive; one of the firmest, latest, best keepers, of finest flavor, sells at high prices. Berries very large, irregular in shape, dark colored. Promises to take its place as the very_best late market variety.

SAMPLE (P)-One of the very best berries and seems to succeed nearly everywhere. Plants strong, large and healthy, producing in profusion large dark colored berries of uniform size and color, firm enough to ship well. One of the standard sorts for both home and market.

SENATOR DUNLAP (S)-This berry is of the Warfield type, has a perfect blossom, is hardy, productive, a splendid keeper and able to hold its own under any "rough and tumble" methods of culture to which it is likely to be subjected. It is a very heavy bearer of good size, even fruit, of a very beautiful dark red color. It is a berry to grow for either home use or market.

WARFIELD (P)-There is probably no better or more profitable berry grown for market. It is in greater demand than any other berry for canning purposes, which also creates a good market for it. Care should be taken to use the right berries as fertilizers. It needs a strong pollinizer.

WM. BELT (S) - The plant is very large, a most luxuriant grower, and remarkably productive. Its blossoms are perfect and it seems that each one is followcd by a berry. It is medium in ripening; its size is very large. In form it is conical, rather long, quite uniform in shape, except that the first berry on a fruit stalk is sometimes misshapen, especially with high culture. The color is a bright glossy red. It ripens all over without green tips. The quality is fine. It is a fine grower of large, well developed berries of excellent quality.

\section{RHUBARB}

This deserves to be ranked among the best early fruits in the garden. It affords the earliest material for pies and tarts, continues long in use, is valuable for canning. Use well grown oots, not divided old clumps.

LINNAEUS - Large, early, tender and fine.

VICTORIA-Very large, long stocks; a great market sort.

\section{ASPARAGUS}

The first garden vegetable of spring; it is a great delicacy and comes in just when it is most needed. One hundred roots will supply a small family and will last for years. Set the plants about eighteen inches apart in the row. Spread the roots ouc in the bottom of the hole or furrow and gradually fill in as the plant grows, so that the roots will be about four inches deep.

CONOVER'S COLLOSAL-Best for general planting.

PALMETTO-Newer variety, earlier; probably as good.

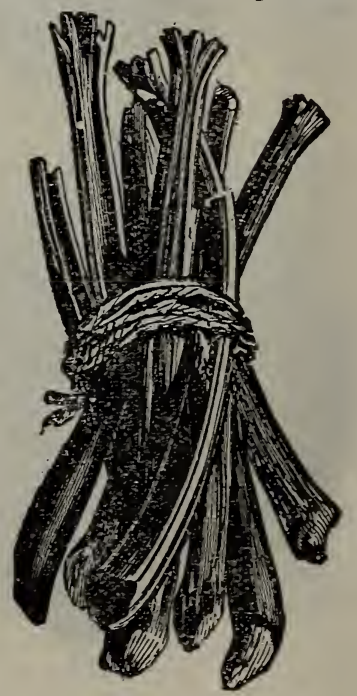




\section{Roses}

Long before history began the rose was loved, as now, for its beauty and fragrance. No home is truly a home without at least a few of these charming plants. Roses love a clayey soil and an open, airy situation, but will do well in any good soil. They well repay good treatment. feeble, sod-bound plants cannot give free bloom. Mulch well with manure. All roses in this climate are benefitted by bcing laid down and covered in winter.

\section{Mosses}

The Moss roses are strong growers and perfectly hardy; they remain in bloom a long time and are especially prized for their beautiful mossy buds.

BLUSH MOSS-Very mossy; fine buds; free bloomer.

CAPTAIN JOHN INGRAM -Dark velvety purple; foliage small, very handsome.

COMTESSE DE IMURINAIS-The finest double white Moss rose, large, beautifully mossed.

SALET-Clear rose color, very double, of vigorous growth and abundant bloom. Perpetual.

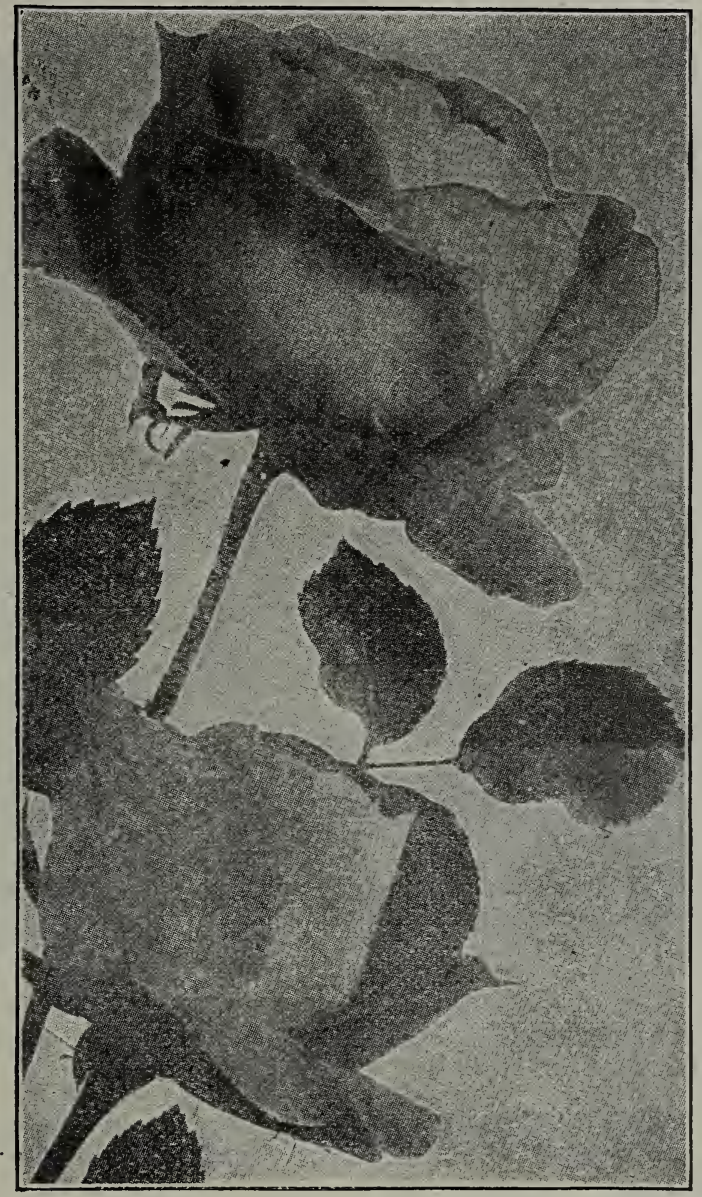

\section{Tree Rose}

'These plants are very attractive with the long branches drooping and trailing to the ground, covered with great clusters of flowers. Flowers are semi-double, but are extremely beautiful on account of their abundance and showy colors. Not hardy. Best to plant in half barrel and give winter protection.

\section{Hybrid Perpetuals}

These are hybrids or crosses between June and Monthly roses, partaking of the hardiness of one parent and the perpetual blooming habit of the other. They are by far the most popular family of roses, needing good soil and culture, as they can only bloom on new shoots of the current season. Free manuring after the first crop will insure better blooms later in the season.

ALFRED COLOMB-Bright carmine red; clear color; large, deeply built form; exceedingly fine.

ANNE DE DIESBACH (Glory of Paris)-Brilliant carmine pink. A superb garden sort; fragrant, one of the hardiest and best.

BARONNE DE BONSTETTIN-Rich, dark red, passing to velvety maroon, highly fragrant; very double.

COQUETTE DES ALPS-One of the finest pure white hybrid perpetuals; large, full, finely formed fower; pure white sometimes faintly tinged with palc blush; profuse bloomer. 


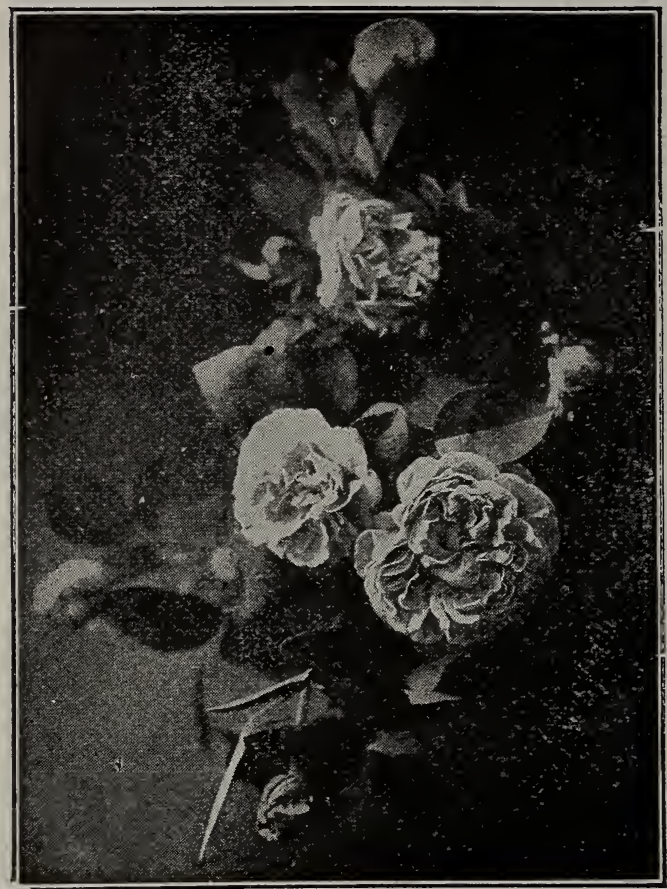

PAUL NEYRON ROSES
COQUETTE DES BLANCHESFlowers of medium size in large clusters, full and slightly fragrant. Snowy, white, sometimes delicately flushed with pale rose.

GENERAL JACQUEMINOTThis might be called the rose for the million, for it is still a universal favorite. Bright crimson-scarlet, exceedingly rich and velvety.

GENERAL WASHINGTONColor brilliant crimson; very rich and beautiful; large, perfectly double and a free bloomer.

JOHN HOPPER-Bright rose with a carmine center, large and full.

MADAM CHARLES WOODFlowers large; dazzling crimson; a constant bloomer; very fine.

MADAM GABRIEL LUIZETPink; very large and fragrant. As an exhibition rose it stands at the head of the list.

MAGNA CHARTA-B r i g h t, clear pink, flushed with violet crimson, flowers large, fine form, sweet, very double and free bloomer.

MRS. JOHN LAING- D e e p rose; large, fine form, fragrant, vigorous grower and hardy. One of the most profuse bloomers.

MARSHALL P. WILDER-New; color cherry carmine; continues in bloom long after others are out of flower: exquisite.

PAUL NEYRON-Deep rose color, good foliage and by far the largest variety in cultivation; one of the best.

PRINCE CAMILLE DE ROHAN-Very dark, rich velvety crimson, passing to intense maroon, shaded black; large full flowers. One of the darkest roses and very handsome.

\section{Climbing Roses}

QUEEN OF THE PRAIRIE-Bright rose in clusters, vigorous, very free bloomer.

SEVEN SISTERS-Fine, free bloomer, bright scarlet; claimed by some to be hardier than Prairie Queen.

\section{Miscellaneous Hardy Roses}

In this collection we have grouped the best of the summer roses, they are hardy, requiring no protection, and thrive in exposed situations where most roses will not grow. Nearly all of them make beautiful hedges and are frequently used for this purpose. They require but little pruning, as most of thcir flowers are borne on the old wood.

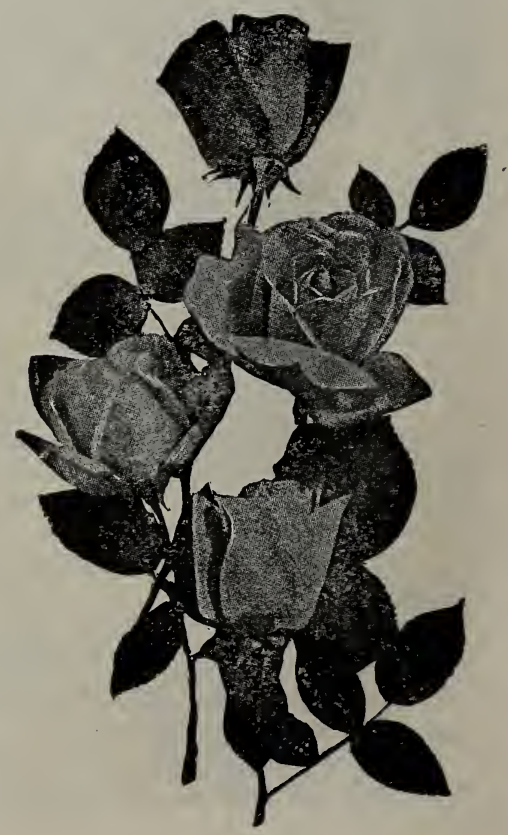




\section{BABY RAMBLER-}

This great novelty originated at Orleans, France, and is a hybrid produced by the crossing of Crimson Rambler and Gloire des Polyanthus. It preserves the prolific flowering quality of the latter, but has the color of the Crimson Rambler (clear brilliant ruby rose). The foliage is of a fine polished dark green and is never attacked by insects or fungus. It blooms in clusters and is very continuous. The time of blooming of the first umbel is not ended when the adjacent branches are ready to open with a considerable number of flowers, so that the period of blooming is not interrupted until after severe frosts. The rose will be very popular on account of its cluster formation being similar to that of the Crimson Rambler, and more particularly because it is covered with flowers the whole summer. We have no hesitation in saying that the bushes of Dwarf Perpetual Crimson Rambler are perfectly hardy and vigorous. The plants grow 24 to 30 inches high. It is not a climber.

HARRISON'S YELLOW-This variety $k$ ooms early, making a brave show with its bright ycllow flowers. It has small faintly fragrant leaves and very thorny stems. In

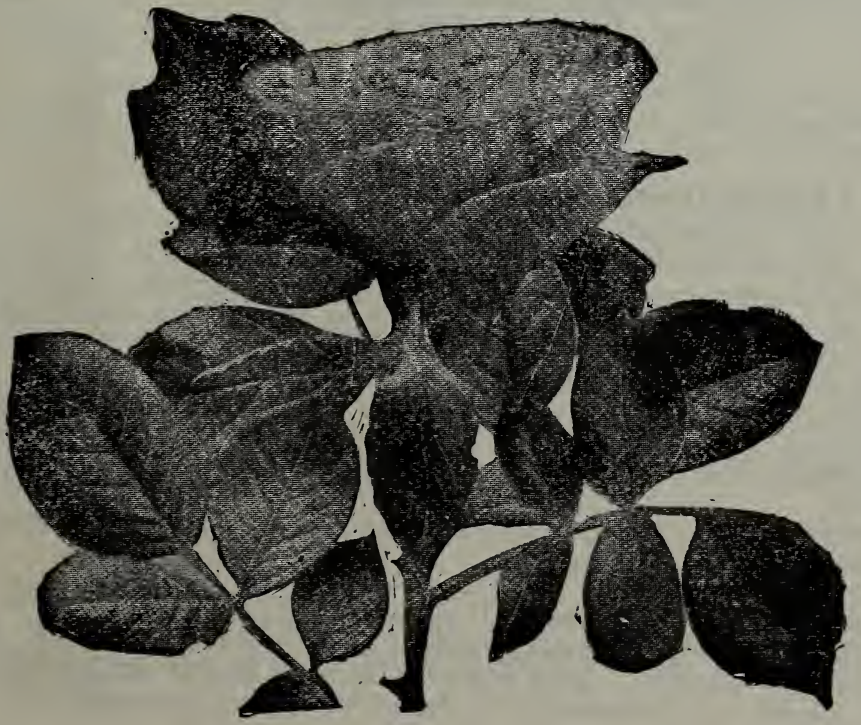
this variety the flowers are. of medium size, semidouble, rich golden yellow, and produced very freely.

PERSIAN YELLOWSimilar to above, but with flowers fuller and of better form. Bright yellow; the most double of this class. The finest hardy yellow rose.

\section{MADAM PLANTIER} -Flowers pure white of medium size; full; somewhat rosy in the bud form produced in greatest abundance quite early in the season. The leaves are small; the bush hardy and spreading. Fine for masses, hedges, border3, cemeteries, etc. 
BLUE RAMBLER ROSE-Veilchenblau (Violet Blue)-The Blue Rambler is a monderful new production. It originated in Germany a little over a year ago and was named Vellchenblau, which means literally, a violet-blue rose. As it is a true Rambler seedling from the original Japanese stock, we have named it the BLUE RAMBLER and it will be so classed among the leading nurserymen. The stock is wonderfully hardy, standing out without any protection during the coldest freezing weather, and is fully as rapid a grower as the crimson variety. The color is a rich Violet-blue. Planted beside the Crimson and White varieties, we have three hardy free flowing ramblers-the red, white and blue, our National Colors.

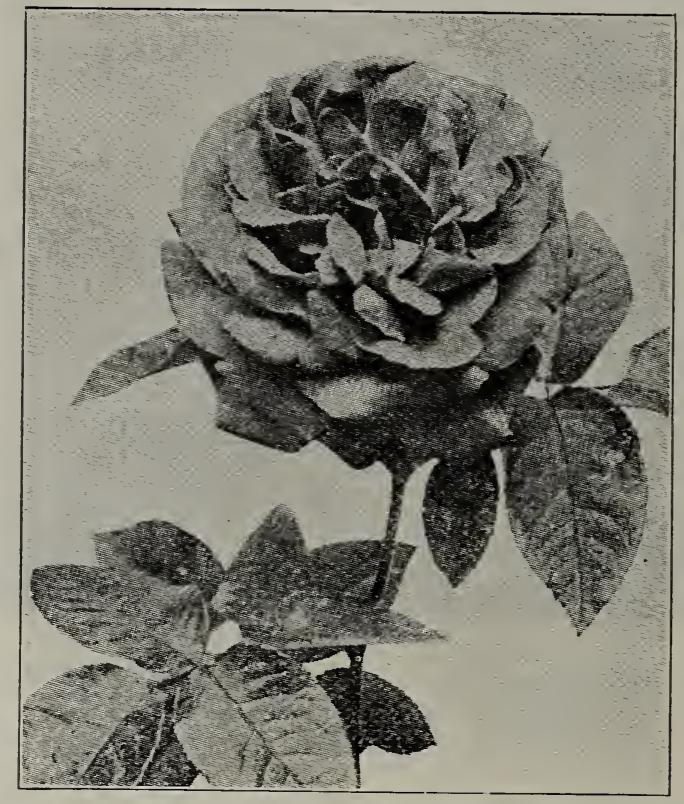

CRIMSON RAMBLER-Nothing equals this as an all round hardy garden rose, on account of its brilliant color, profusion of bloom and length of time the flowers last. It may be used as a climber, or can be grown in large bush form. It blooms in large clusters of 50 to 100 flowers in a cluster, covering the foliage its entire length with a solid mass of the most beautiful perfectly shaped miniature crimson blossoms. Blooms last of June and remains in flower longer than any other hardy out-door rose.

DOROTHY PERKINS-This is a splendid new, shell-pink climbing rose. This new rose is of the same strong habit of growth as Crimson Rambler, and the flowers are borne in clusters of thirty and forty and sometimes even fifty to sixty. The flowers are large for a rose of this class. Very double, sweetly scented and fine.

PINK RAMBLER - A lovely climbing rose. Flowers light, delicate pink or blush and about as iarge as a twenty-five cent piece. Blooms middle of June in immense clusters. YELLOW RAMBLER-Bud beautiful bright yellow, opening straw color fading to a beautiful creamy white. Blooms middle of June. Not so desirable as the crimson.

WHITE RAMBLER-Pure snowy white, flowers are double. Blooms middle of June. Not very satisfactory.

\section{Ornamental Shrubs}

The pıanting of ornamental shrubs is very largely on the increase, and this is as it should be, for with a good selection the lawn can always be beautiful. They are mostly of medium size, enabling one to plant a great variety on a small plot, and the wonderful assortment of foliage from the darkest green and purple to light orange and silver tints. This addition to the great variety in the blossoms, all unite to keep up a never failing interest. We have selected the very best for our climate.

FLOWERING SHRUBS-Variegated or Colored Foliage-Berberry, Golden Elder, Syringa Variegated, Weigelia.

Shrubs that Flower in May-Flowering Almonds, Honeysuckle, Japan Quince, Lilac, Snowballs, Spireas, Wisteria.

In June-Clematis, Deutzia, Elder, Honeysuckle, Paeonias, Lilacs, Snowball, Spireas, Syringia, Weigelia, Wisteria.

In July-Clematis, Spirea, Honeysuckle.

In August and September-Bignonia, Clematis, Honeysuckle, Hydrangea.

ALTHEA, or ROSE OF SHARON-Valuable because they bloom so profusely in late summer when other flowers are scarce. They form beautiful groups or hedges, their variety of colors making it possible to use quantities of them even in small grounds. 
ACACIA ROSE-This is one of the finest old shrubs in cultivation, perfectly hardy and an absolute blaze of beauty when in bloom.

ALMOND, FLOWERING-Pink and white varieties. These beautiful shrubs are desirable and scarce. Hardy.

CALYCANTHUS (Carolina Allspice)-A well known native bush bearing very double, purple fragrant flowers.

DEUTZIA - A very desirable shrub, of strong, hardy growth, bearing an abundance of beautiful racemes of double, pure white flowers.

ELDER GOLDEN-The leaves are a bright and constant golden color; the flower cluster pure white. Valuable for contrasts and for massing.

e HONEYSUCKLE, UPRIGHT-White and pink flowers which contrast beautifully with the foliage. Blossoms in June.

HYDRANGEA PANICULATA GRANDIFLORA-These plants are absolutely hardy, grow in any soil and bloom the same year they are set out. They flower abundantly,

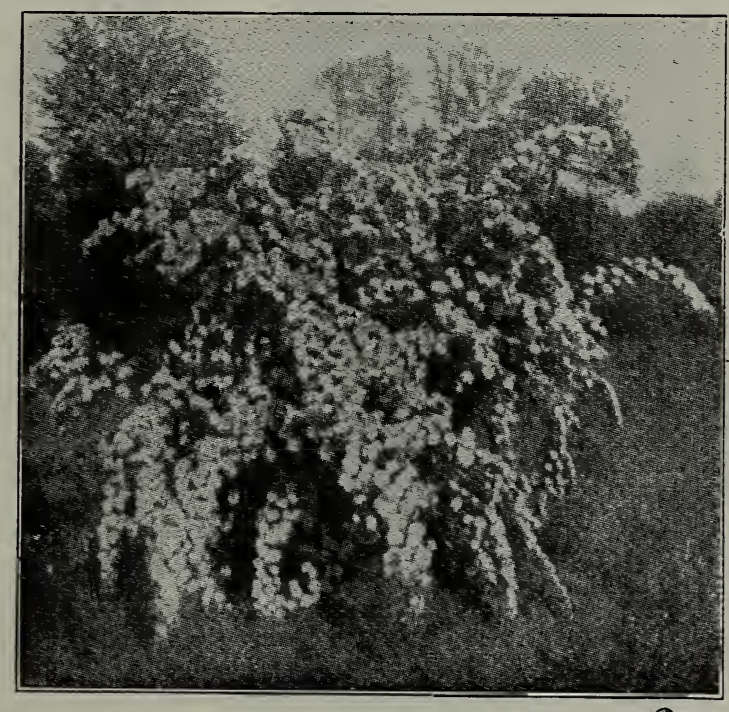

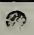

VAN HOUTTEI SPIREA

bearing hundreds of immense panicles of bloom. White turning to rose in autumn. An annual shortening of branches tends to increase the size of the flowers. Very fine and valuable for cemetery planting.

LILAC (Common Purple)-Bluish purple flowers, well known.

LILAC (Common White)-Cream white flowers.

LIIAC (Persian Purple)-Of more slender growth and finer foliage than the common lilac. Flowers purple in large loose panicles.

SNOWBALL (Common)-A popular shrub. Makes a large bush. Bears balls of pure white flowers in June.

SPIREAS-Decidedly the best and hardiest family of shrubs for the Northwest. Many beautiful varieties of different colors and times of flowering, from May to September. Of easiest culture; should be planted everywhere.

S. AUREA-Golden leaf Spirea, with white blooms and golden foliage; very showy.

S. BALLARDII-Blooms in beautiful rose colored spikes from early summer till frost. Hardy and very desirable.

S. VAN HOUTEI-Graceful, with long drooping sprays, thickly studded with handsome, pure white flowers; hence its popular name, "Bridal Wreath." The finest Spirea of them all. 


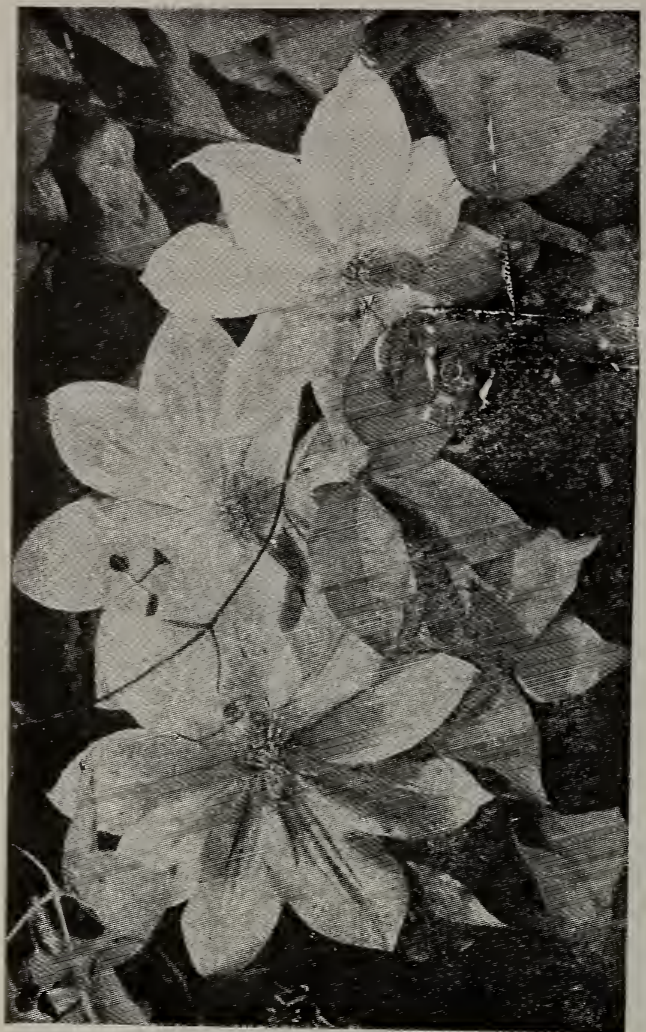

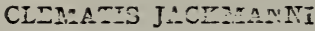

S. COLLOSA ROSEA-F 1 o w e r s from June to September; of a pretty dwarfish habit; bloom rose color.

SYRINGA (Mock Orange)-Beautiful, tall, vigorous, hardy, with profuse, white orange-like flowers in May. Very Popular.

TREE CRANBERRY - Resembles the snowball in wood and foliage. Its acid fruit is highly esteemed.

WEIGELIA ROSEA-Hardy, with profuse rosy, trumpet shaped flowers in May. The most superb shrub of the season.

\section{Hardy Climbing Vines}

Ornamentals of this class are so hardy and so beautiful that they deserve greater attention than they receive. No artist can produce pictures equal to the wealth of beauty displayed by the elegant Wisteria, the graceful Honeysuckle, or the charming and magnificent Clematis when in the glory of full bloom and there is nothing in art that will in any way compare with the gorgeous hues of the Ampelopsis after it assumes its brilliant autumnal tints.

AITPELOPSIS (American Ivy or Virginia Creeper, also called Woodbine)-A very rapid grower, having beautiful dark green foliage, assumes rich crimson hues in autumn.

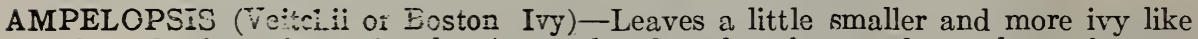
in form than the foregoing. Overlapning each other they form a dense sheet of green. The plant requires a littlo protcction the first winter until it is established.

BIGNONIA (Scarlet

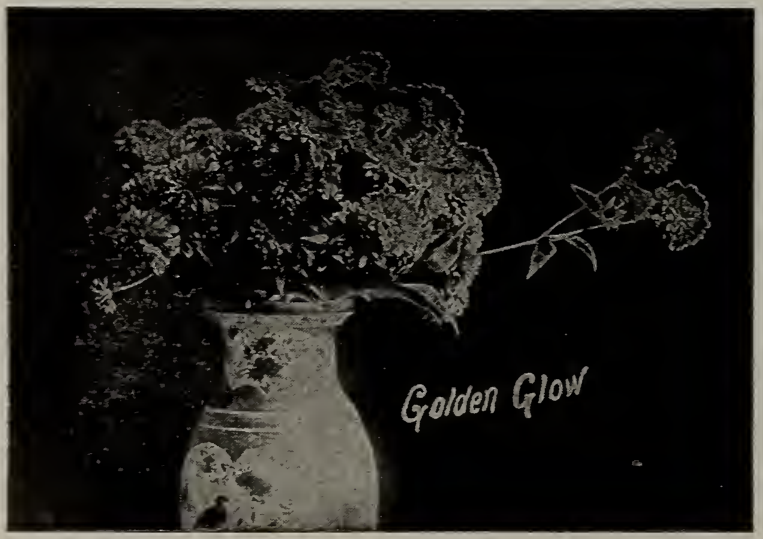

Trumpet Flow e r) -A splendid climber, vigorous and hardy, with clusters of large trumpet-shaped scarlet flowers in August.

CLEMATIS-The different varieties and species of Clematis now in cultivation are of the highest beauty and utility They vary greatly in their foliage and flowers and are adapted to various uses.

C. COCCINEA - Distinct from other varieties; bright coral scarlet flowers. July to October. 
C. FLAMMULA-The flowe $\_$of this variety are very fragrant; requires a slight protection in winter; very desirable.

C. JACKMANNI-A very profuse blooming variety with flowers from four to six inches in diameter, of an intense violet-purple color borne successionally in continuous masses on the summer shoots. The very best sort for general planting.

C. HENRYII-Fine bloomer; flowers large, of a beautiful creamy white, consisting generally of from six to eight sepals. June to October.

C. MADAME EDOURD ANDRE-Flowers large, of a beautiful bright velvety red, very free flowering and continuous bloomer.

C. PANICULATA-A great novelty. One of the most desirable, useful and beautiful of hardy garden vines, a luxuriant grower, profuse bloomer with fine foliage. Flowers of medium size, very pretty and fragrant, produced in the greatest profusion in late summer.

HONEYSUCKLE (Monthly Fragrant)-Blooms all summer; very sweet.

HONEYSUCKLE (Hall's Japan)-A strong, vigorous, evergreen variety with pure white flowers changing to yellow. Very fragrant; covered with flowers from June to November. Better have some winter protection.

WISTARIA-A most beautiful climber of rapid growth, producing long, pendulous clusters of pale blue flowers. When well established makes an enormous growth. It is very hardy and one of the most superb vines ever introduced.

\section{Hardy Herbaceous Perennials}

DAHLIAS-Well known autumn flowering plants, growing from two to five feet high, and producing a profusion of flowers of the nost perfect and beautiful form, varying in color from the purest white to the darkest maroon.

GLADIOLUS-Of all oursummer flowering bulbs gladiolus stand at the head of the most varied and beautiful class. The flowers are produced in spikes two feet in height and upwards; the brilliant scarlet and crimson of some form a striking contrast with the delicate shades and penciling of the lighter colored varieties. By planting at intervals from May 1st to middle of June a succession of flowers can be had from July to October.

GOLDEN GLOW-We call attention to this notable novelty and offer it as the finest herbaceous border plant introduced for many years. It is of easy growth and is giving complete satisfaction. But few plants can vie with it in attractiveness. There is no floral novelty before the public to be compared to it for effectiveness and worth.

PAEONIAS-Herbacious $\mathrm{Pa}$ eonias are among the showiest and most useful of hardy plants, and are fast becoming popular with the public. They are all hardy and admirably adapted to the climate of our most northern states, growing well in almost any location or soil, although

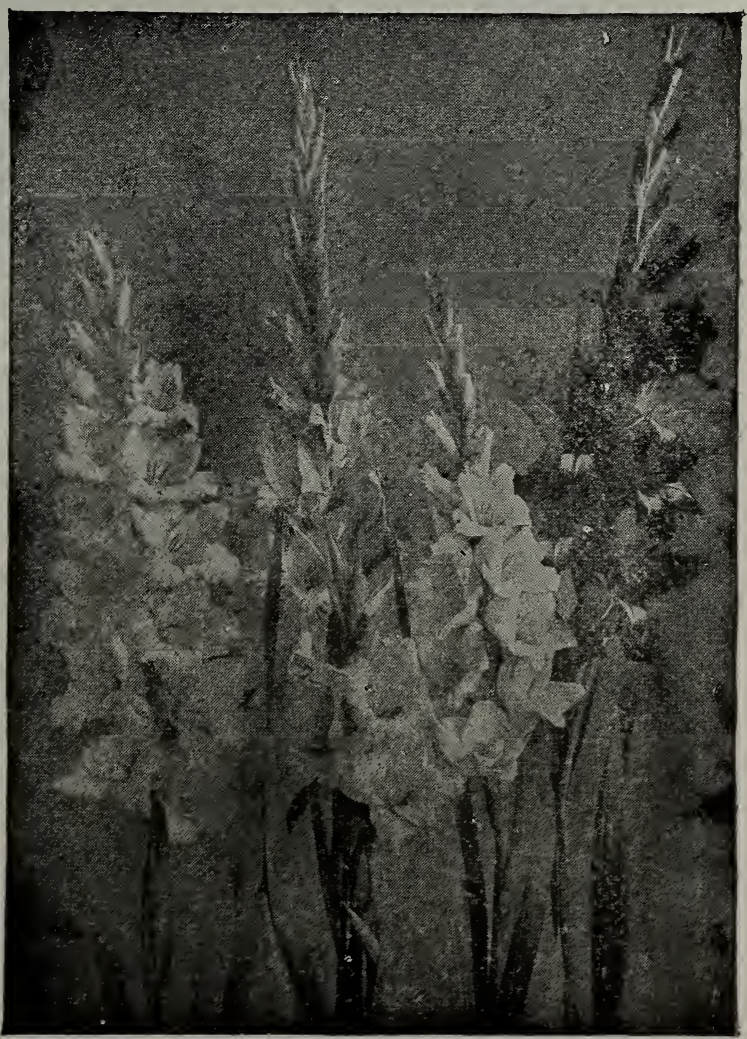




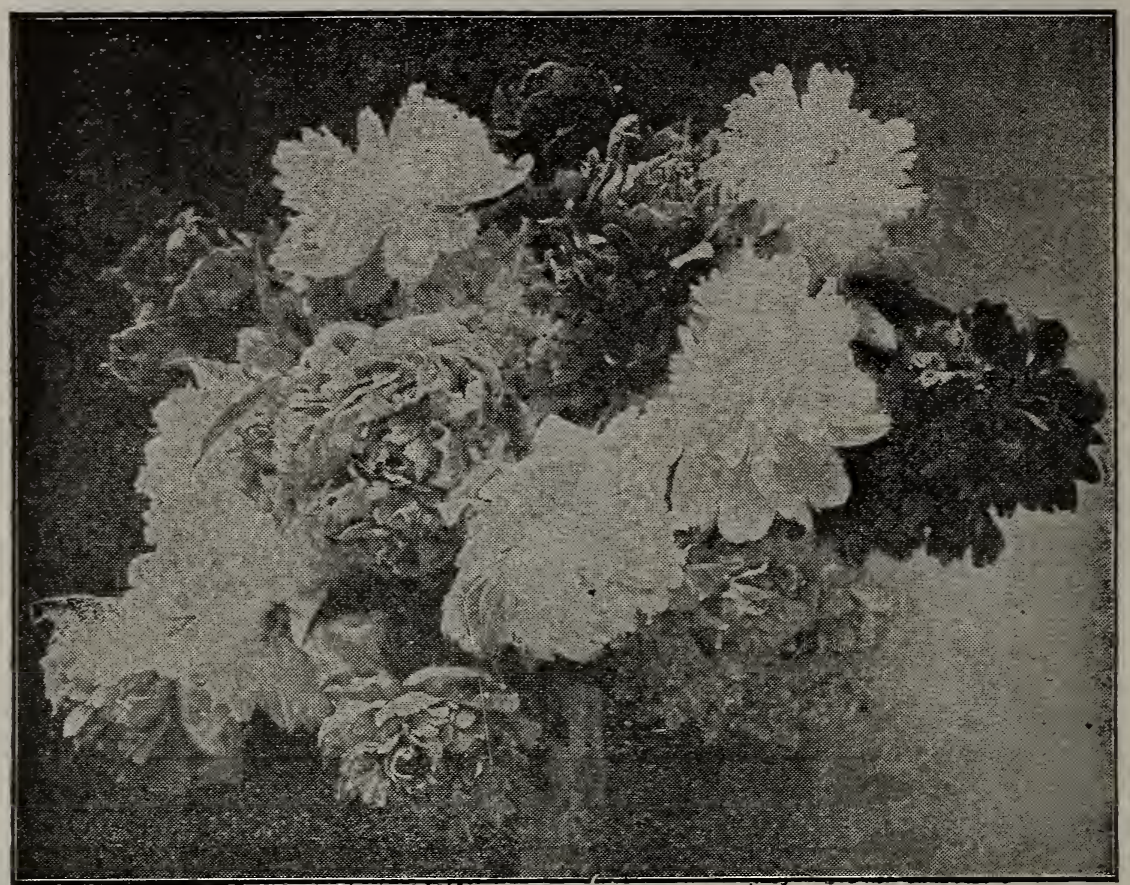

GROUP OF PAEONIES

the flowers will be finer and the colors brighter, if planted in a deep rich loam, well manured. The flowers are in all shades, from red and lilac to white, with blooms from four to eight inches in diameter. Many of them are very double and have a delicate and refreshing fragrance.

YUCCA FILAMENTOSA (Adam's Needle)-Thread-leaved, creamy white; stem three to four feet high, covered with bell-shaped flower, on laterals forming a pyramid; very striking.

\section{Flowering Bulbs to be Planted in the Fall}

CHROCUS-In various colors, single and double.

HYACINTHS-Among the bulbs used for winter flowers, Hyacinth stands foremost on the list. Two methods are employed in flowering the hyacinth in winter, one in glasses filled with water, the other in pots or boxes of soil.

JONQUILS-Pretty varieties of the Narcissus, have a very agreeable fragrance; adapted to either pots or out-door culture. The bulbs being small six or eight may be put in a six-inch pot.

LILLIES-The lillies are entirely hardy with few exceptions. Quite fragrant and most of the varieties are very beautiful.

LIIIUM AURATUM - Gold banded lily of Japan.

L. CANDIDUM-Common white.

L. HARRISII (Bermuda Easter Lily)-Pure white trumpet shaped flowers, very fragrant. The finest lily grown.

L. LANCIFOLUM ROSEUM (Rose Spotted).

L. LANCIFOLIUM RUBRUM (Red Spotted).

L. TIGRINUM (Double Tiger Lily)-Bright orange scarlet with dark spots.

LILY OF THE VALLEY - This lily is as hardy as any plant can possibly be, and when planted in open ground will increase pretty rapidly.

TULIPS-Owing to the late spring frosts, bedding plants cannot safely be planted before the early spring flowering bulbs are through blooming. They thrive well in almost any soil. Should be planted during October and November. 


\section{Hedge Plants}

BERBERRY (Purple Leaf)-An interesting and beautiful variety with violet purple leaves and red fruit.

JAPAN QUINCE-Unquestionably a fine plant for an ornamental hedge. Grows very compact; will submit to any amount of pruning, while the brilliant and showy scarlet flowers make it exceedingly attractive.

PRIVET (Amoor River or Russian)-This is the most beautiful hedge plant grown. It has a luxuriant glossy leafage and thick clusters of fragrant white flowers. Hardy, free-growing, of dense neat habit; attractive all the year, in berry, leaf, or flower. Makes a beautiful specimen plant, a fine screen, group or hedge.

PRIVET (California)-One of the finest for hedges where it does not winterkill. The foliage is large and glossy, and is almost evergreen. While we can furnish the California Privet for hedging purposes, we do not recommend it as being absolutely hardy north of the 41st parallel of latitude.

OSAGE O RANGE-One of the very best for defensive $h$ edges where it can be grown without winter killing. It is of vigorous habit, and rapid, dense growth, and when ke p t properly trimmed it not only makes an effective hedge, but it is decidedly ornamental

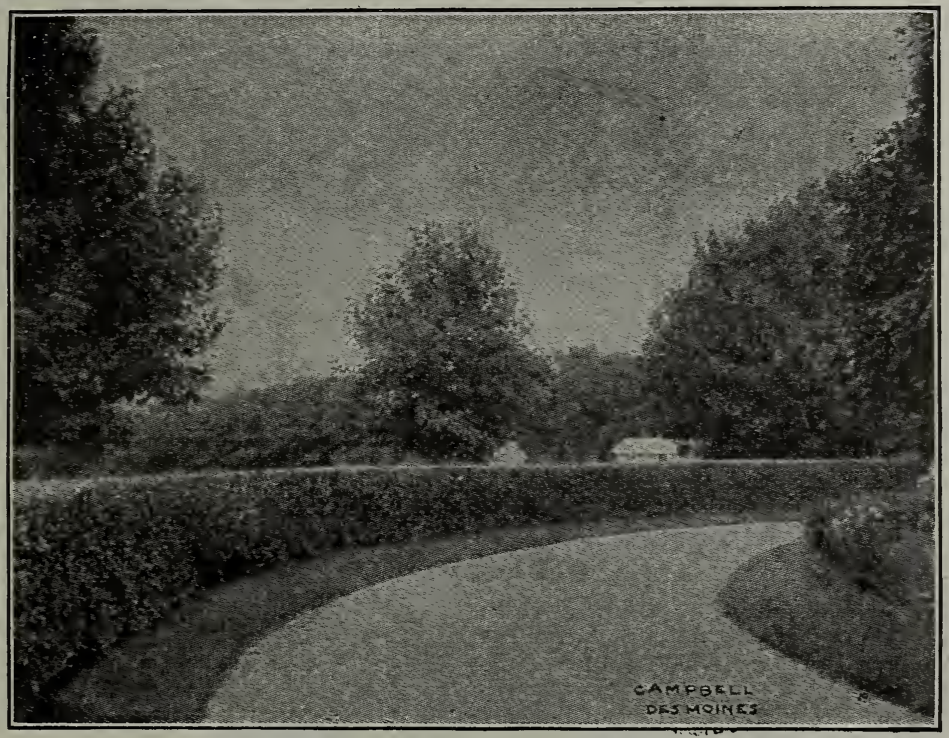

PRIVET HEDGE

\section{Hardy Ornamental Trees}

The stock of ornamental trees that we offer will be found to comprise a sufficient number of kinds that are really valuable, so that our customers may, from the list offered, secure such a variety as will give full satisfaction. Windbreaks of trees, more especially if they are evergreens, besides being ornamental make the dwellings warmer, diminishing to an extent the consumption of fuel. They also make the outbuildings warmer for stock by night and the yard by day imparting comfort to the animals and saving a large amount of food.

\section{A List of Trees Recommended for Various Purposes}

For Streets, Roads and Wide Avenues-American Elm, Sugar and Silver Maple, Carolina Poplar.

For Driveways through Lawns and Parks-Norway Maple, Tulip Tree, Catalpa, American Linden.

Single Specimens of Large Growth to be Branched from the Ground-Birches, particularly Cut-Leaf Weeping; Austrian and Scotch Pines, Norway and Colorado Spruces, Balsam Fir.

Single Specimens of Medium Growth to be Branched from the Ground-Prunus Pisardii, Hemlocks, White Pine, Arbor Vitae.

Strong Growing Trees of Pyramidal Habit-Carolina Poplar, Balsam Fir, Pyramidalis Arbor Vitae. 
Trees that Thrive in Moist Locations-American Elm, American Linden, Ash, Catalpas, Poplars and Willows.

Trees that Thrive on Dry Knolls or Poor Soils-Silver Leaf Maples and Poplars.

Best Trees for Windbreaks-Norway and White Spruces, Scotch and White Pine, Carolina Poplars and Silver Maples.

Flowering Trees-Judas Tree, Fringe Tree, White and Purple Lindens, Horse Chestnut, Catalpas.

Cut-Leaved Trees-Cut-leaf Weeping Birch, Weirs Cut-leaf Maple.

Purple and Scarlet-Leaved Trees-Purple-Leaf Beech, Plum, Purple Norway Maple.

ASH, WHITE-Rapid growing tree, of fine, symmetrical outline. A valuable street or park tree and should be extensively planted.

BIRCH, WHITE-A beautiful native tree,particular in the northern part of the country. Its shining white bark and slender dark brown branches make it a conspicuous and very attractive object. Foliage large and handsome.

BOX-ELDER-A fine, rapid growing tree, with handsome, light green pinated foliage and spreading head; very hardy.

CATALPA-A native of the South. A rapid growing, beautiful tree, with very large heart-shaped leaves and pyramidal clusters of white and purple flowers a foot long. Blooms late in July.

CHESTNUT, AMERICAN or SWEET - Well known beautiful tree, valuable for fruit and timber. Should be planted only in thin, dry soils.

CHESTNUT, HORSE-Common or white, flowering. A very beautiful, well known tree, with round, dense head, dark green foliage, and an abundance of showy flowers in early spring.

ELM, AMERICAN WHiTE-The noble, spreading, drooping tree of our woods. One of the grandest of park or shade trees.

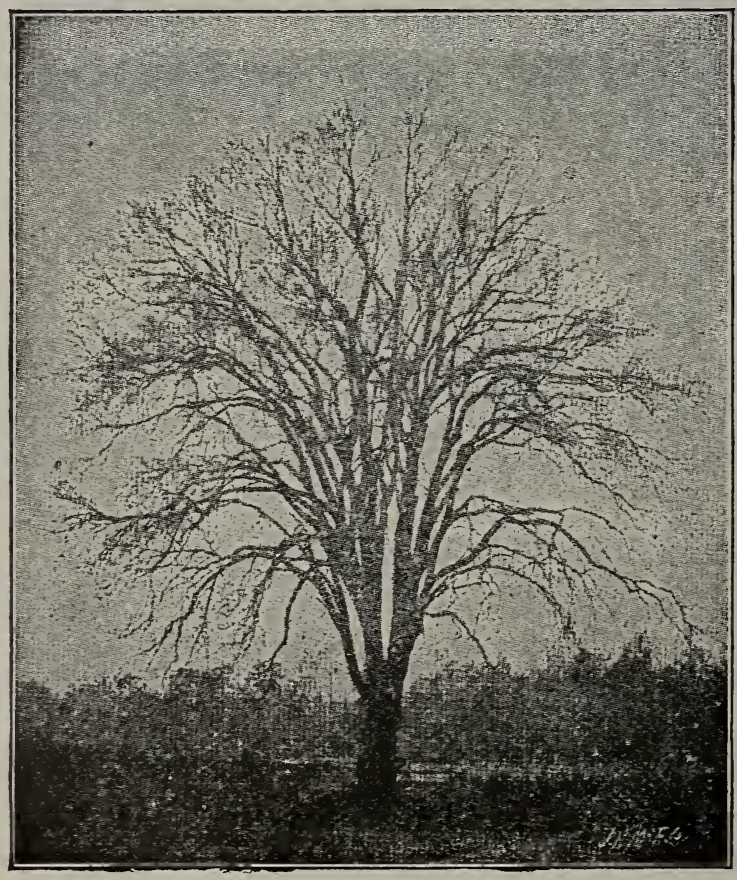

AMERICAN ELM
FRINGE, PURPLE-Very conspicuous in mid-summer when veiled with a thick mist of dusty purple flowers, so light as to simulate wreaths of smoke. This is sometimes called "Smoke Tree."

FRINGE, WHITE-A beautiful little tree, with large, soft, heavy leaves, almost hidden in spring time by clouds of delicate, fragrant white flowers of a droop ing, fringe-like character.

LINDEN (American or Lime) A rapid growing, large, beautiful native tree. Flowers very fragrant.

MAPLE (Silver Leaved)Leaves white underneath; of rapid growth; very ornamental and one of the best street trees we have.

N OR W A Y M A P L E-Of spreading, rounded form; foliage large, dark green; a rich and majestic shade tree.

SUGAR MAPLE-A beautiful, stately tree of fine form; a desirable shade tree. Slow grower. 
MAIDEN HAIR or GINKO TREE-One of the most beautiful, lawn trees, beautiful rich, glossy, fern-like foliage. Rapid growth. A tall upright grower.

CRAB (Bechtel's Double Flowering)-This blooms in early spring exhaling a most delightful fragrance from its masses of double delicate pink flowers.

ELEGANUS ("Russian Wild Olive") - A very hardy and quite a rapid growing tree with a silvery foliage; very striking in appearance. Its ability to endure extreme cold and drouth makes it desirable for ornamental lawns and for hedges.

MOUNTAIN ASH-Very hardy and handsome with fine clusters of scarlet berries hanging on the trees in the winter; a beautiful tree for the lawn.

CAROLINA POPLAR-Takes front rank among best of poplars; it is one of the most rapid growers among shade trees. Its branches spread just enough to give it a symmetrical appearance. It has advantages over other shade trees because it will grow on any kind of soil, swampy or muck, light or heavy. Its roots penetrate the hardest soil, it withstands all hardships and thrives in places where others fail to -live. It is easily started and gives shade in a short time. Its leaves are large and stay green till quite late in the fall.

PLUM (Prunus Pissardii)Purple leaved. One of the most beautiful purple leaved trees or shrubs. The leaves and shoots are of a rich, peculiarly vived dark purple, holding the color well through the entire season. It also produces small, white, single flowers in great profusion in May, followed by black fruit of ornamental appearance. Winter pruning gives stronger shoots and darger leaves.

WALNUT, BLACK-Valuable for nuts and timber. It is hardy and succeeds best on a rich, deep, moist soil. Too well known for long description.

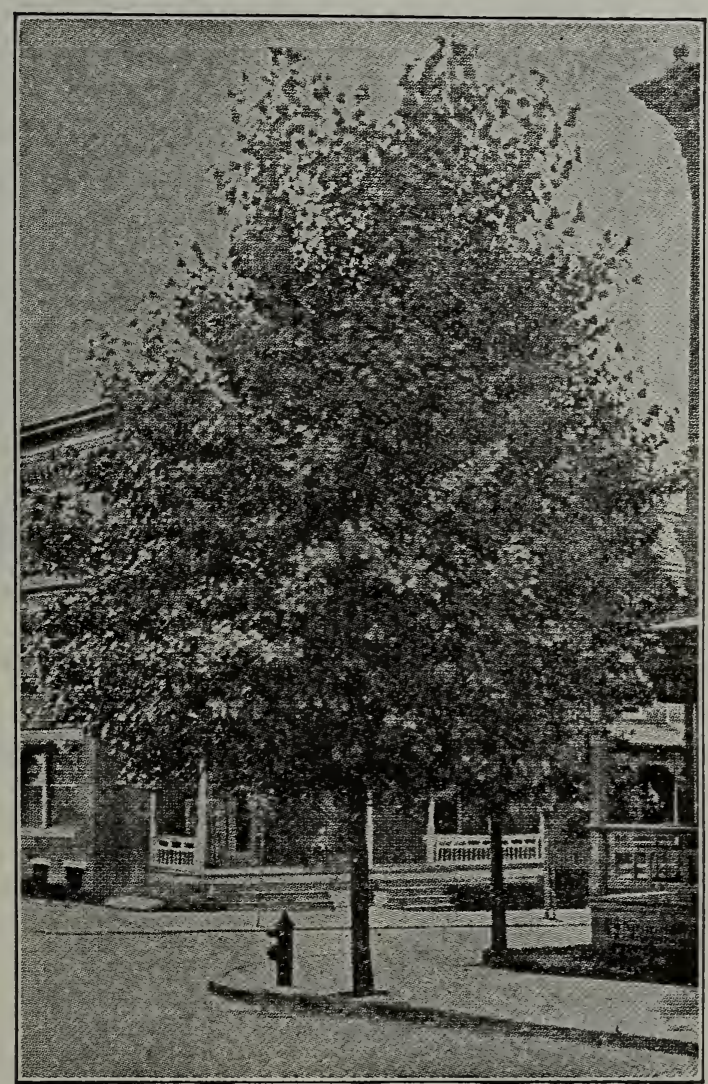

CAROLINA POPLAR

\section{Weeping Ornamental Trees}

BIRCH (Cut-Leaf Weeping)-Erect, stately, rapid growing tree, with long, slender, pendant branches, delicately cut leaves and silvery white trunk; especially fine when near evergreens; hardy; the most elegant weeping tree on the list.

ELM CAMPERDOWN, WEEPING-A vigorous grower; leaves large, dark green and glossy, covering the tree with a luxuriant mass of verdure; very desirable as an ornamental.

MOUNTAIN ASH (European Weeping)-A strong grower; remarkably pendant; perfectly hardy; succeeds admirably on prairie soil. 
TEAS' WEEPING MULBERRY-Forms a perfect umbrella shaped head, with long slender branches drooping to the ground, paralleled to the stem; very hardy; one of the prettiest small weeping trees.
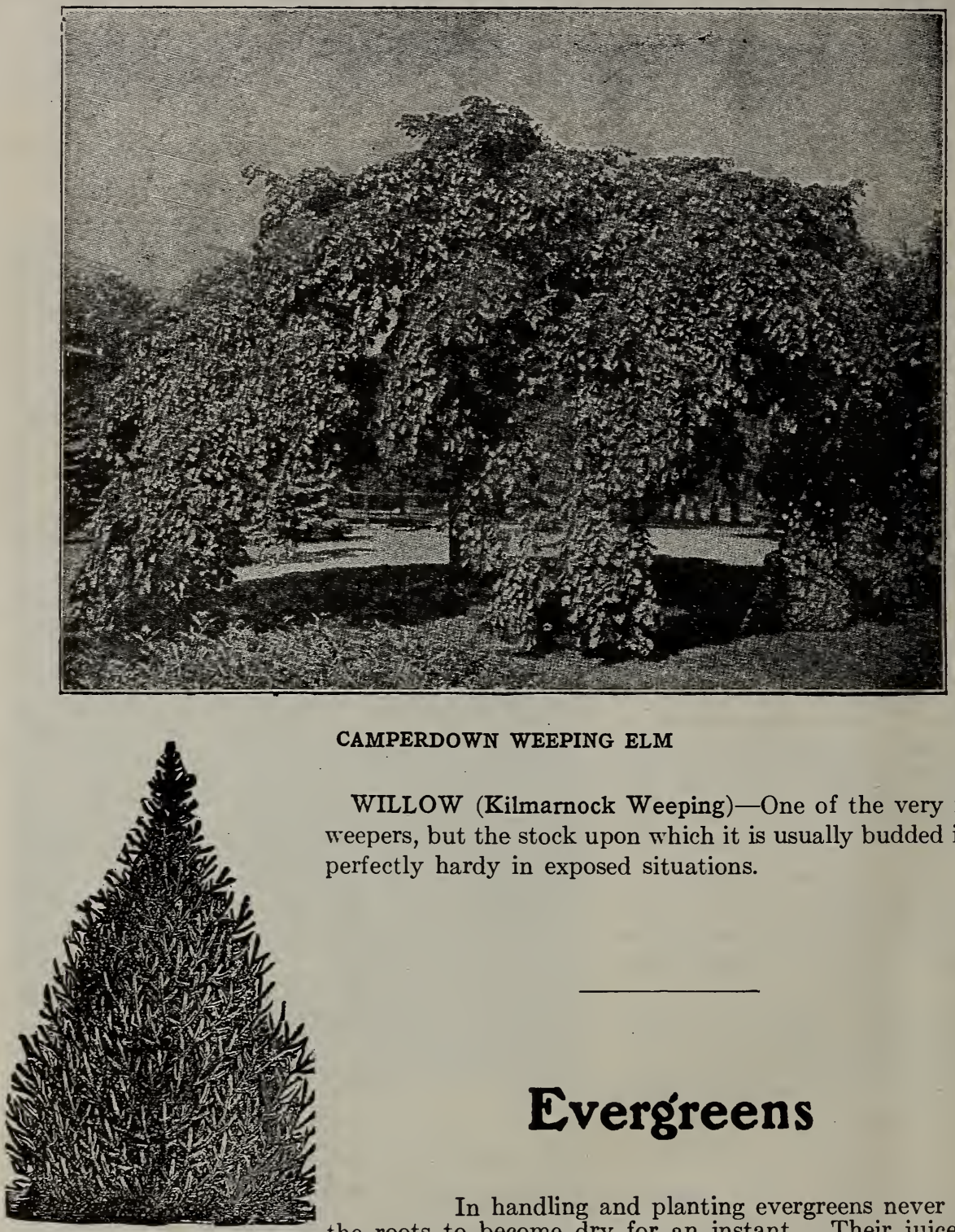

CAMPERDOWN WEEPING ELM

WILLOW (Kilmarnock Weeping)-One of the very finest weepers, but the stock upon which it is usually budded is not perfectly hardy in exposed situations.

\section{Evergireens}

In handling and planting evergreens never allow the roots to become dry for an instant. Their juices are resinous, and when once dry, water has no power to restore them; dip the roots in "grout" or very thin mud, and plant quickly; cover the roots with fresh soil and with a heavy piece of wood beat the earth solid over them. Fill up and pound again, and finish by bringing fresh loose earth about the tree with a hoe. No wind can now bend the trees about so as to break the tender rootlets as fast as formed. If trees are planted when soil is very wet, the pounding must be omitted until in working order to prevent baking; planted in this way and thoroughly cultivated with plow and hoe every week, evergreens seldom fall to give abundant satisfaction. A heavy mulch July 1 st and they are all right for the season. 
For wind-breaks a single row of pines or spruces, eight feet apart, or a double row ten feet each, the two rows breaking joints, will, in a few years, become a living wall.

Use Scotch Pine, White Spruce, Norway Spruce, and White Pine for high screens, and Arbor Vitae or Red Cedar for low ones.

\section{ARBOR VITAE (American)-}

This plant is, all things considered, the finest evergreen for hedges. It is very hardy and easily transplanted, few plants failing if properly handled. It grows rapidly and with little care, or rather by easy management, it soon forms a most beautiful hedge, very dense and perfectly impervious to the sight. It is never planted to turn stock, but it forms a most desirable and ornamental screen to divide the lawn from other grounds.

ARBOR VITAE (Pyramidalis)A superb, new and hardy sort, of very compact habit; much better than the Irish Juniper, and grows in a perfect column.

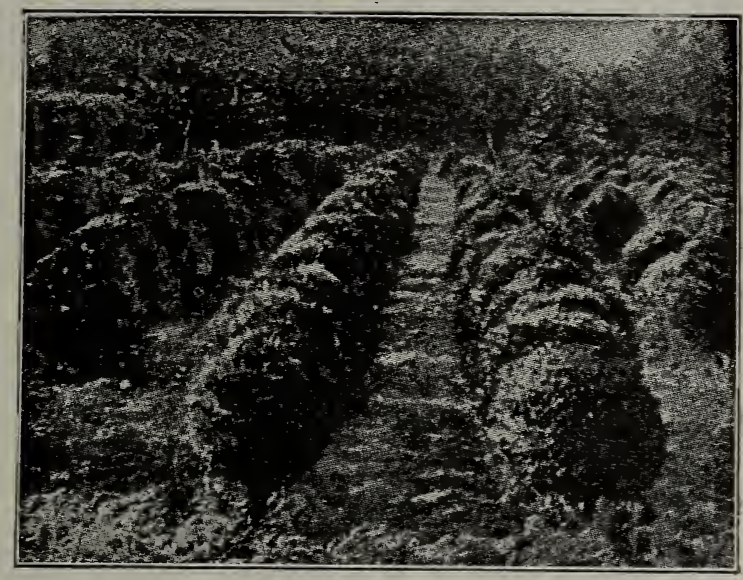

ARBOR VITAE-AMERICAN

Largely planted in cemeteries, owing to the small amount of space it occupies. This is perhaps the most valuable Arbor Vitae in cultivation.

BALSAM FIR-A handsome, compact, erect, pointed tree, with short, soft leaves, which are dark green above, silvery beneath; a good grower.

HEMLOCK-An elegant pyramidal tree, with drooping branches and delicate dark foliage, like that of the Yew; distinct from all other trees. It is a beautiful lawn tree and makes a highly ornamental hedge.

PINE, AUSTRIAN or BLACK-A remarkably robust, hardy, spreading tree; leaves long, stiff, dark green; growth rapid; valuable for this country.

PINE, SCOTCH-Is one of the most rapid growers while young, one of the best for shelter planting in the West. It will make the best windbreak in the least time of any; it is a very valuable species.

PINE, WHITE-One of the best evergreens. The foliage is a warm, light green, often with a bluish tinge. The leaves, in fives, are three or four inches long, soft and delicately fragrant. It does not grow as rapidly the first few years as some, but after being planted eight or ten years it is the most rapid grower of all our evergreens.

SPRUCE, COLORADO BLUE-This species has been tested at various points on the prairies of the West and Northwest with perfect cuccess, and during a temperature of 30 degrees below zero, in exposed situations, entirely uninjured. One of the hardiest evergreens and the most beautiful in color and outline. "This is the king of spruces, clothed in royal robes of silver and sapphire, a very Kohinnor among the gems of the Rockies."

SPRUCE, NORWAY - A lofty, elegant tree of perfect pyramidal habit, exceedingly picturesque and beautiful. One of the best evergrrens for windbreaks. handsome.

SPRUCE, WHITE-A tall tree with compact branches and light green foliage. Very 


\section{WHEN TO SPRAY.}

APPLE TREES-For prevention of leaf blight, spraying with Bordeaux mixture or Ammoniacal Carbonate of Copper as soon as the leaves are full grown. To destroy aphis or plant lice, spray with kerosene emulsion as soon as the pests appear. To destroy the codlin moth, canker worm and curcuilo, spray with paris green or London purple, $1 / 4$ pound in forty or fifty gallons of water, soon after the blossoms fall, and again two weeks later. To destroy web worm spray with London purple or kerosene emulsion from August 1st to 10 th or as soon as pests appear. This application should be made during the middle of the day, when the worms are out of their webs and feeding on the leaves.

\section{CHERRIES-Treatment same as recommended for the apple.}

PEARS-The pear slug can easily be destroyed by spraying with paris green, four ounces to fifty gallons of water, or with kerosene emulsion, as soon as the slug begins operation. Pear and quince blight can be destroyed by spraying with Bordeaux mixture. The codlin moth and curculio should be treated same as recommended for apple trees.

PLUMS-Destroy the aphis with kerosene emulsion and a fine spray nozzle. The curculio can be destroyed by spraying with 3 ounces Paris green to forty gallons of water. First application should be made as soon as blossoms have fallen, and repeated at intervals of a week or ten days. Four applications should be sufficient. Other enemies of the plum will be destroyed by this method, but in all cases be particular to keep the poison and water constantly stirred.

PEACHES-If attacked by the black peach aphis, spray with kerosene emulsion. The plum curculio frequently attacks the peach in which case spray with paris green, $2 \mathrm{oz}$. to 50 gallons of water; be sure to keep it well stirred and use with caution. Never use London Purple on peach trees.

\section{FOR GRAPE ROT AND MILDEW-Use Bordeaux Mixture.}

CURRANTS AND GOOSEBERRIES - To destroy the worms, spray with powdered Hellebore, one ounce in three gallons of water, as soon as the worms appear. To destroy the yellow aphis, spray with kerosene emulsion early in the season. To prevent mildew use one-half ounce potassium sulphide to one gallon of water.

\section{FORMULAS.}

KEROSENE EMULSION-In making kerosene emulsion for spraying trees for lice, be sure and follow the correct method. Dissolve in two quarts of water, one quart of soft soap or one-fourth pound of hard soap by heating to the boiling point, then add one pint of kerosene oil and stir violently for from three to five minutes. This may be done by using a common force pump and putting the end of the hose back into the mixture again. This mixes the oil permanently, so that it will never separate, and it may be diluted easily at pleasure. This mixture should be diluted to twice its bulk with water or about fourteen times as much water as kerosene. The kerosene emulsion is successful in destroying cattle lice and sheep ticks, as well as all varieties of plant lice.

BORDEAUX MIXTURE-Six pounds of sulphate of copper are dissolved in six gallons of water. In another vessel four pounds of fresh lime are slacked in six gallons of water, after the latter solution has cooled, slowly turn it into the other solution and add ten gallons of water. This, when all is thoroughly mixed and strained is ready for use. In straining this mixture, reject all of the lime sediment using only the clear liquid. Strain the white-wash through a coarse gunny sack stretched over the head of a barrel.

COPPER SULPHATE SOLUTION-Copper sulphate, 1 pound; water, 15 gallons. Dissolve the copper sulphate in the water, when it is ready for use. This should never be applied to foliage, but must be used before the buds break. For peaches and nectarines use 25 gallons of water. Use for fungous diseased 


\section{FORMULAS}

PARIS GREEN. Paris green, 1 pound; water, 200 gallons. If this mixture is to be used upon peach trees, 1 pound of quicklime should be added. Repeated applications will injure most foliage, unless lime is added. Paris green and Bordeaux mixture can be applied together with perfect safety. Use at the rate of 4 ounces of the arsenites to 50 gallons of the mixture. The action of neither is weakened, and the Paris green loses all caustic properties. Use for insects which chew.

HELLFBORE. Fresh white hellebore, 1 ounce; water, 3 gallons. Apply when thoroughly mixed. This poison is not so energetic as the arsenites, and may be used a short time before the sprayed portions mature. Use for insects which chew. Can also be used dry by dusting on plants.

LONDON PURPLE. This is used in the same proportion as Paris green, but as it is more caustic it should be applied with two or three times its weight of lime, or with I3ordeaux mixture. The composition of London purple is exceedingly variable, and unless good reasons exist for supposing that it contains as much arsenic as Paris green, use the latter poison. Do not use London purple on peach or plum trees unless considerable lime is added. Use for insects which chew.

LIME, SULPHUR AND SALT. Stone lime, 15 to 30 pounds; flowers of sulphur, 15 pounds; salt, 15 pounds; water, 50 gallons. Slake the lime in a small quantity of hot water, gradually adding and thoroughly stirring in the sulphur. Dilute the mixture with twelve gallons of water and boil in an iron kettle or cook by steam in a covered tank or barrel for one and one-half hours. Then add salt, continuing the boiling for one-half hour more. Fill vessel up with water to the required fifty gallons. Strain wash through a fine mesh strainer and apply hot. In using an iron kettle, keep the mixture vigorcusly boiling and thoroughly stirred to prevent caking and burning of materials. Wash cooked by steam is more easily prepared and better made. Apply wash just as the buds begin to swell in the spring. Cover all parts of the tree with a heary coat of the wash. The wash seems best adapted to orchardists who have not yet learned to use petroleum with safety or are afraid that their trees are beginning to show injury from the oil or will not stand many more applications of it. It is especially recommended for the treatment of peach trees. It is believed that the substitution of one and one-fourth pounds of blue vitriol dissolved in hot water for the salt results in quicker-acting wash. This formula is known as the Oregon Wash. Use for scale and fungous diseases.

Any of the Agricultural Experiment Stations will furnish bulletins so arranged that the grower may see at a glance what to apply, when and how to make the applications.

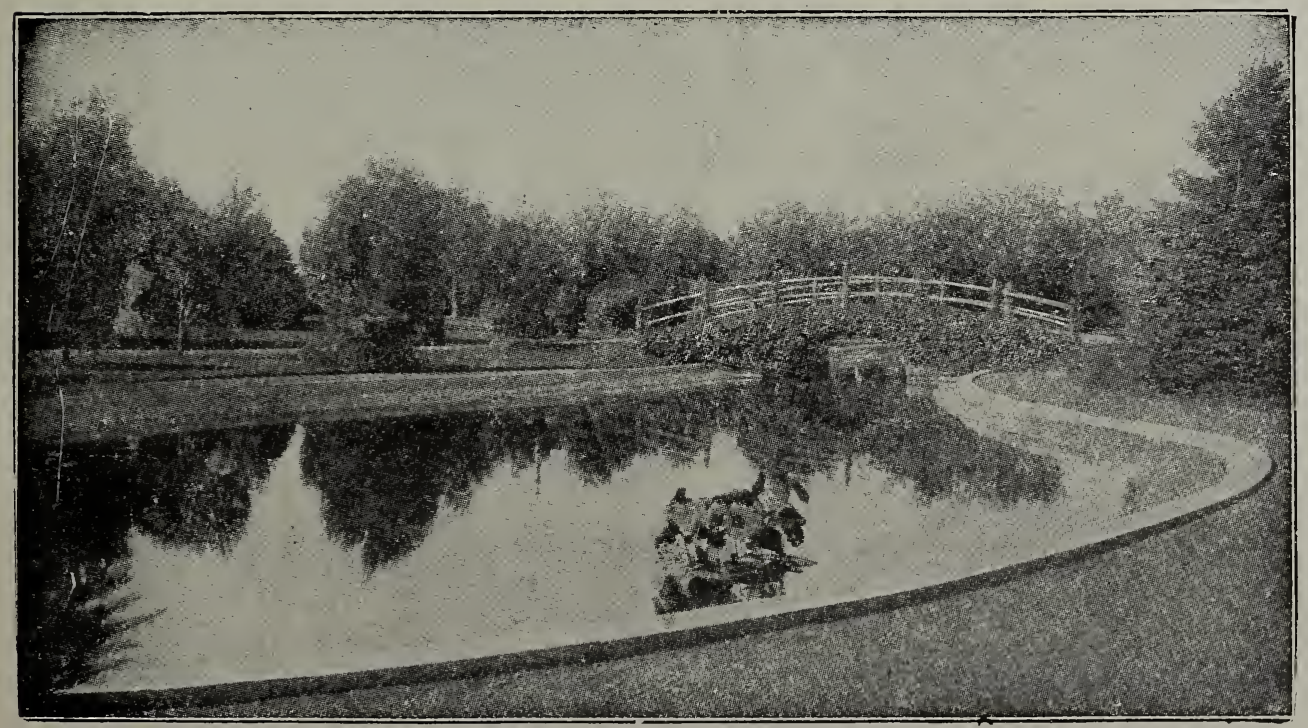




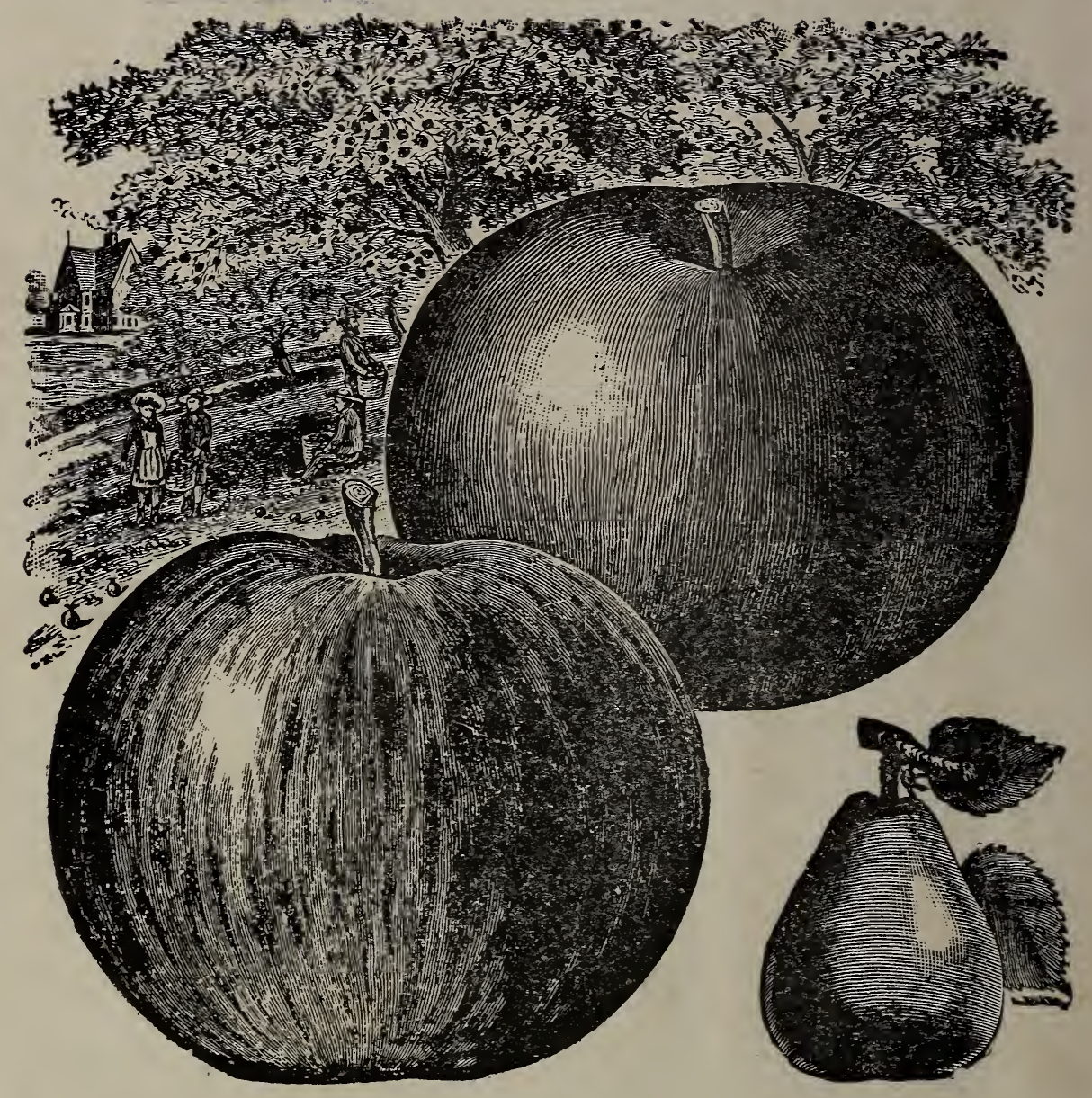

CAMPBELL-JOHNSON PRINTING CO.

Horticulteral Printers

$91619 \mathrm{y} \forall W$

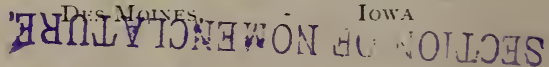
ADOTOHOd OL NUULLA 